\title{
CITRANDARINS E OUTROS HÍBRIDOS DE TRIFOLIATA COMO PORTA- ENXERTOS NANICANTES PARA A LARANJEIRA 'VALÊNCIA' (Citrus sinensis L. Osbeck)
}

\author{
SILVIA BLUMER
}

Tese apresentada à Escola Superior de Agricultura "Luiz de Queiroz", Universidade de São Paulo, para obtenção do título de Doutor em Agronomia, Área de Concentração: Fitotecnia.

PIR A C I C A B A

Estado de São Paulo - Brasil

Fevereiro - 2005 


\section{CITRANDARINS E OUTROS HÍBRIDOS DE TRIFOLIATA COMO PORTA- ENXERTOS NANICANTES PARA A LARANJEIRA 'VALÊNCIA' (Citrus sinensis L. Osbeck)}

\section{SILVIA BLUMER}

Engenheiro Agrônomo

Orientador: Dr. JORGINO POMPEU JUNIOR

Tese apresentada à Escola Superior de Agricultura "Luiz de Queiroz", Universidade de São Paulo, para obtenção do título de Doutor em Agronomia, Área de Concentração: Fitotecnia.

PIR A C I C A B A

Estado de São Paulo - Brasil

Fevereiro - 2005 
Dados I nt er naci onai s de Cat al ogação na Publ i cação ( CI P) DI VI SÃO DE BI BLI OTECA E DOCUMENTAÇÃO - ESALQI USP

\section{Blumer, Silvia}

Citrandarins e outros híbridos de trifoliata como porta-enxertos nanicantes para a laranjeira 'Valência' (Citrus sinensis L. Osbeck) / Silvia Blumer. - - Piracicaba, 2005. 118 p. : il.

Tese (Doutorado) - - Escola Superior de Agricultura Luiz de Queiroz, 2005. Bibliografia.

1. Declínio do citros 2. Gomose 3. Melhoramento genético vegetal 4. Poliembrionia vegetal 5. Porta-enxerto 6. Tangerina 7. Tristeza cítrica I. Título

CDD 634.31

"Permi tida a cópi a tot al ou parcial deste documento, desde que citada a f ont e - O aut or" 
À Deus, pelo livre arbítrio.

Aos meus pais Leonardo e Antonieta pelo amor.

A minha irmã Eveline pelo exemplo.

A minha tia Marta por contribuir para a minha formação

E a minha sobrinha Luísa, por sempre me perguntar o por quê??

Ao Jorgino, pelo companheirismo. 


\section{AGRADECIMENTOS}

Ao Dr. Jorgino Pompeu Junior, do Centro APTA Citros "Sylvio Moreira", pela cessão do experimento e orientação.

Ao Prof. Dr. David Ariovaldo Banzatto, da Faculdade de Ciências Agrárias e Veterinárias - Unesp - Jaboticabal, pela orientação nas análises estatísticas.

A Fazendas Reunidas Raio de Sol.

Ao Dr. Eduardo Feitchenberger, da Unidade de Pesquisa e Desenvolvimento de Sorocaba da APTA/SAA, pela cessão do isolado de Phytophthora parasitica.

Ao Centro APTA Citros "Sylvio Moreira" pela colaboração na realização deste trabalho.

À bibliotecária, Silvia Zinsly, da Esalq/USP, pela revisão da referências.

A CAPES,Fapesp, Fundecitrus e CNPq, pelo auxílio financeiro. 


\section{SUMÁRIO}

Página

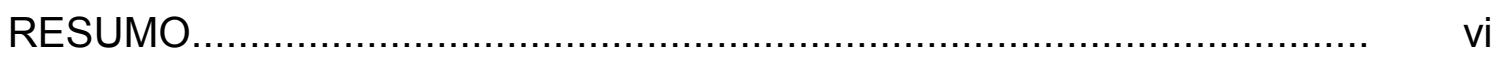

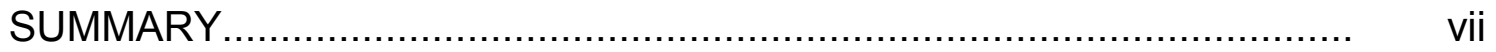

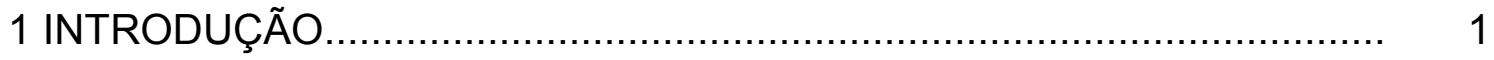

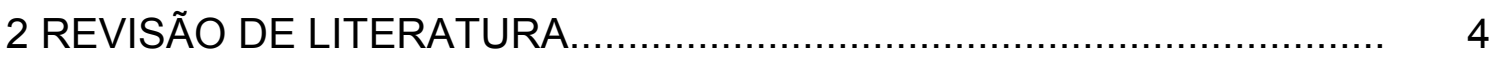

2.1 Melhoramento de porta-enxertos.................................................... 4

2.2 Características dos parentais dos porta-enxertos envolvidos neste trabalho e de alguns de seus híbridos........................................................... 8

2.3 Fatores a serem considerados na escolha de porta-enxertos ............... 14

2.3.1 Tolerância à tristeza dos citros ................................................... 15

2.3.2 Resistência ao declínio dos citros ............................................. 16

2.3.3 Tolerância à morte súbita dos citros ........................................... 18

2.3.4 Resistência à gomose de Phytophthora......................................... 19

2.3.5 Influência dos porta-enxertos no tamanho das plantas..................... 21

2.3.6 Embrionia nucelar e poliembrionia ................................................. 23

2.3.7 Incompatibilidade entre copa e porta-enxerto ................................. 25

3 MATERIAL E MÉTODOS ............................................................. 28

3.1 Área experimental .................................................................... 28

3.2 Tratamentos e delineamento experimental ................................... 29

3.3 Avaliações.......................................................................... 30

3.3.1 Produção de frutos................................................................ 30

3.3.2 Altura, diâmetro e volume das copas ............................................ 30

3.3.3 Eficiência produtiva das copas .................................................. 31

3.3.4 Qualidade dos frutos ........................................................ 31

3.3.5 Tolerância à tristeza.............................................................. 32 
3.3.6 Resistência ao declínio

3.3.7 Resistência dos porta-enxertos à gomose de Phytophthora

3.3.8 Determinação das características dos frutos e da poliembrionia das sementes dos citrandarins e dos híbridos de trifoliata

4 RESULTADOS E DISCUSSÃO

4.1 Influência dos porta-enxertos na produção de frutos

4.2 Altura, diâmetro e volume das copas em 2004

4.3 Eficiência produtiva das copas

4.3.1 Considerações teóricas sobre produção, tamanho das plantas e espaçamento

4.4 Qualidade dos frutos ....

4.5 Produção de frutos e sólidos solúveis por planta

4.6 Resistência dos porta-enxertos a Phytophthora parasitica

4.7 Tolerância dos porta-enxertos à tristeza dos citros

4.8 Resistência dos porta-enxertos ao declínio dos citros

4.9 Características dos porta-enxertos

4.9.1 Determinação do número médio de embriões e da poliembrionia das sementes dos porta-enxertos

4.10 Ocorrência de incompatibilidade entre a laranjeira 'Valência' e trangpur Cravo x Carrizo (717)

5 CONCLUSÕES 


\section{CITRANDARINS E OUTROS HÍBRIDOS DE TRIFOLIATA COMO PORTA- ENXERTOS NANICANTES PARA A LARANJEIRA 'VALÊNCIA' (Citrus sinensis L. Osbeck)}

AUTORA: SILVIA BLUMER

ORIENTADOR: Dr. JORGINO POMPEU JUNIOR

\section{RESUMO}

Laranjeiras 'Valência' enxertadas em citrandarins e outros híbridos de trifoliata foram plantadas em 1988, em Itirapina (SP), num Latossolo Vermelho-amarelo-textura arenosa e conduzidas sem irrigação. Os citrandarins Sunki x English (1.628), Cleópatra x Rubidoux (1.660) e Cleópatra x English (710), induziram as maiores produções de frutos nas cinco e nas treze colheitas. Os citranges 'Troyer' e 'Carrizo' foram significativamente menos produtivos que o Sunki x English (1.628) nas cinco primeiras e no total das treze colheitas. Os citrandarins Clementina x Trifoliata (1.615), Cleópatra x Swingle, seleções (715) e (1.614), Cleópatra $x$ Rubidoux (1.600) e Cleópatra $x$ Christian (712) induziram plantas nanicas. Sunki x English (1.628), 'Troyer' e 'Carrizo' proporcionaram as maiores plantas e lideraram a produção de frutos e de sólidos solúveis no período 2001-2003. Nenhuma planta mostrou sintomas de suscetibilidade à tristeza ou ao declínio. As plantas enxertadas no trangpur Cravo x Carrizo (717), mostraram sintoma de incompatibilidade na região de enxertia. "Seedlings" dos citrandarins Cleópatra x Swingle (1.587), Cleópatra x Trifoliata (1.574) e Cleópatra $x$ Rubidoux (1.600) foram mais resistentes à gomose de Phytophthora parasitica que os demais porta-enxertos. 


\title{
CITRANDARINS AND OTHERS TRIFOLIATE HYBRIDS AS ROOTSTOCKS FOR 'VALENCIA' SWEET ORANGE (Citrus sinensis L. Osbeck) TREES.
}

\author{
AUTHOR: SILVIA BLUMER \\ ADVISER: Dr. JORGINO POMPEU JUNIOR
}

\section{SUMMARY}

'Valência' sweet orange trees budded onto citrandarins and others trifoliate hybrids rootstocks were planted in 1988 on a sandy textured Oxisol in São Paulo state, Brazil, and managed without irrigation. Tristeza and blight diseases are endemic in the area. Trees on Sunki x English (1628), Cleopatra $x$ Rubidoux (1660) and Cleopatra $x$ English (710), produced the highest cumulative yields in the first five and in the thirteen crops. 'Carrizo' and 'Troyer' citranges gave the lowest productions in the first five yields but were similar to Sunki x English (1628) in 13-years cumulative yields. Clementine $x$ Trifoliate (1615), Cleopatra $x$ Swingle (715) and (1614) selections, Cleopatra $x$ Rubidoux (1600) and Cleopatra $x$ Christian (712) induced dwarfed trees. Sunki $x$ English (1628) and 'Troyer' and 'Carrizo' citranges induced the largest trees and fruit and soluble solids production by tree in the 2001-2003 period. None tree showed symptoms of tristeza or declinio. Trees on Cravo x Carrizo (717) showed bud-union-ring symptom of incompatibility. Seedlings of Cleopatra $x$ Swingle (1587), Cleopatra x Trifoliate (1574) and Cleopatra x Rubidoux (1600) were more resistent to Phytophthora parasitica infections than the others rootstocks. 


\section{INTRODUÇÃO}

Desde a introdução dos citros no Brasil por volta de 1540, até o início do século $\mathrm{XX}$, as plantas cítricas foram propagadas por sementes. Apenas quando a citricultura alcançou expressão comercial iniciou-se o uso dos porta-enxertos, sendo as laranjas doces, entre as quais a laranja 'Caipira' [Citrus sinensis (L.) Osb.], o porta-enxerto mais utilizado, provavelmente pela facilidade de obtenção das sementes. A baixa resistência da 'Caipira' à gomose de Phytophthora spp. e à seca motivou a sua substituição pela laranja 'Azeda' [C. aurantium (L.)], que foi o principal porta-enxerto até o final da década de 1940. Nessa época, supõe-se que $90 \%$ das plantas estavam enxertadas na laranja 'Azeda' e, as demais, em lima da 'Pérsia' (C. limettioides Tan.), limão 'Cravo' (C. limonia Osb.), laranja 'Caipira' e limão ‘Rugoso' (C. jambhiri Lush.).

A introdução do vírus da tristeza dos citros no Estado de São Paulo, por volta de 1937 (BITANCOURT, 1940), e a sua disseminação pelo pulgão-preto (Toxoptera citricidus Kirk.) e por borbulha (MENEGHINI, 1946) causou a morte das plantas enxertadas em laranja 'Azeda' e lima da 'Pérsia'. Os experimentos que vinham sendo desenvolvidos pela Escola Superior de Agricultura "Luiz de Queiroz" desde 1925 (VASCONCELLOS, 1939) e pelo Instituto Agronômico desde 1933 (MOREIRA, 1946) e as observações em pomares comerciais revelaram que as plantas enxertadas em limão 'Cravo', tangerina 'Cleópatra' (C. reshni hort. ex Tan.), tangerina 'Sunki' [C. sunki (Hayata) hort. ex Tan.], laranja 'Caipira' e limão 'Rugoso' não manifestavam os sintomas da doença. Esses porta-enxertos foram considerados tolerantes à tristeza e utilizados na reconstrução da citricultura. 
Alguns porta-enxertos, entre eles o limão 'Cravo', manifestaram outras doenças, como a exocorte e a xiloporose (MOREIRA, 1954, 1955). O controle dessas viroses, desprovidas de vetores, passou a ser feito com a utilização de borbulhas retiradas de plantas matrizes de clones nucelares derivados das cultivares infetadas (MOREIRA, 1962; MOREIRA \& SALIBE, 1965).

O uso dos clones nucelares associado as excepcionais características do limão 'Cravo' - facilidade na obtenção das sementes e formação das mudas, compatibilidade com todas as cultivares copa, bom "pegamento" das mudas no plantio, rápido crescimento, produção precoce, alta produção de frutos, boa resistência à seca, boa adaptação aos solos arenosos e ácidos - tornaram-no, a partir de 1960, o principal porta-enxerto da citricultura paulista. Mesmo com o surgimento do declínio dos citros, nos anos 70 (RODRIGUEZ et al., 1979), e comprovada sua suscetibilidade a tal anomalia, o limão 'Cravo' continuou a predominar nos novos plantios. O declínio promoveu pequena diversificação dos porta-enxertos, liderada pela tangerina 'Cleópatra' e seguida pela tangerina 'Sunki', e, a partir do início da década de 1990, pelo citrumelo 'Swingle' [C. paradisi Macfad. x Poncirus trifoliata (L.) Raf.] ( POMPEU JUNIOR, 2001).

Desde 1999, uma nova doença, detectada no Sudoeste de Minas Gerais e no Norte do Estado de São Paulo e denominada de morte súbita dos citros (MSC), vem afetando laranjeiras e tangerineiras enxertadas em limão 'Cravo' (GIMENES-FERNANDES \& BASSANEZI, 2001) e em limão 'Volkameriano' (C. volkameriana V. Ten. \& Pasq.) (BASSANEZI et al., 2003). As plantas enxertadas sobre as tangerinas 'Cleópatra' e 'Sunki', citrumelo 'Swingle' e trifoliata [P. trifoliata (L.) Raf.] não mostram sintomas.

A MSC acelerou a diversificação dos porta-enxertos. Levantamentos realizados pelo Fundo de Defesa da Citricultura (Fundecitrus), revelaram que, em 2000, o limão 'Cravo' participava de $87,4 \%$ das mudas, 
seguido pela tangerina 'Cleópatra' com 6,3\% e pelo citrumelo 'Swingle' com $3,5 \%$ vindo a seguir o trifoliata e o limão 'Volkameriano' com 1,4 e 1,0\%, respectivamente, e a tangerina 'Sunki' com 0,4\%. Já em fevereiro de 2004, apenas $44,8 \%$ das mudas estavam enxertadas em limão 'Cravo', seguido pelo citrumelo 'Swingle' com 20,6\%, tangerina 'Cleópatra' 18,8\% e limão 'Volkameriano' com 7,3\%, e pelo trifoliata e a tangerina 'Sunki', com $4,2 \%$ cada (BLUMER et al., 2004). Como esses porta-enxertos são menos tolerantes à seca que o limão 'Cravo', a citricultura paulista será mais suscetível a esse evento climático.

A esses fatores limitantes ao pleno desenvolvimento da citricultura paulista deve ser acrescentada a impossibilidade da prática da irrigação na maior parte da área atualmente ocupada pelas plantas cítricas, o que torna necessário a seleção de porta-enxertos com boa tolerância à seca.

A seleção de porta-enxertos também deve levar em conta o tamanho das plantas. Plantas menores e com alta eficiência produtiva permitem maior densidade de plantio e maior produtividade. A menor altura favorece a inspeção e o controle das doenças e pragas, reduz os custos e aumenta a segurança das colheitas.

Neste trabalho são apresentados os resultados da avaliação do comportamento de laranjeiras 'Valência' [C. sinensis (L.) Osb.] enxertadas em citrandarins e outros híbridos de trifoliata, produzidos pelo United States Departament of Agriculture, Florida, EUA e introduzidos no Centro APTA Citros "Sylvio Moreira", Cordeirópolis (SP) em 1982, em comparação com os citranges 'Troyer' e 'Carrizo' [P. trifoliata (L.) Raf. x C. sinensis (L.) Osb.]. Elas foram comparadas quanto à produção e características dos frutos, tamanho das plantas, tolerância à tristeza e ao declínio e compatibilidade com os portaenxertos. Eles também foram avaliados quanto resistência à gomose de Phytophthora parasitica e a poliembrionia. 


\section{REVISÃO DE LITERATURA}

\subsection{Melhoramento de porta-enxertos}

Embora a enxertia dos citros já fosse conhecida desde o século $\mathrm{V}$, considera-se que o principal indutor da transição da citricultura de pés francos para a de plantas enxertadas, foi o surgimento da gomose de Phytophthora na Ilha dos Açores em 1842 e seu controle mediante porta-enxertos resistentes, entre os quais a laranja 'Azeda' (CHAPOT, 1975). Posteriormente, por volta de 1890, foi observado na África do Sul e na Austrália, o declínio de laranjeiras e tangerineiras enxertadas em laranja 'Azeda', o que levou a sua substituição pelo limão 'Rugoso'. A princípio, considerado como uma forma de incompatibilidade entre copas e porta-enxertos, teve a sua origem virótica, transmissão por borbulha e pelo pulgão-preto demonstrada no Brasil em 1946 (MENEGHINI, 1946). A inviabilidade do controle do vetor obrigou a substituição da laranja 'Azeda' por porta-enxertos tolerantes a essa virose, denominada de tristeza por MOREIRA (1942).

Esses dois eventos são considerados os principais impulsionadores do melhoramento de porta-enxertos em todo o mundo.

No melhoramento de porta-enxertos busca-se a obtenção de variedades que sejam tolerantes/resistentes a fatores bióticos (doenças e pragas) e abióticos (adversidades edafoclimáticas). Dentre os fatores bióticos, destacamos a tristeza, o declínio, à gomose e os nematóides. Já, em relação 
aos fatores abióticos, os porta-enxertos devem possuir boa tolerância à altos teores de alumínio, à salinidade, ao frio, ao encharcamento e à seca. Além disso, é desejável que o porta-enxerto induza boa produção e qualidade de fruto, possua facilidade de propagação, seja compatível com as principais variedades copa e contribua para a maior longevidade das plantas.

Os primeiros programas de melhoramento de porta-enxertos basearam-se em métodos tradicionais de seleção de variedades e clones e também em hibridações controladas.

Após as devastadoras geadas ocorridas na Flórida em 1894-1895, H.J. Webber e W.T. Swingle iniciaram, em 1897, o primeiro programa de melhoramento por hibridação realizado pelo United States Departament of Agriculture, Florida, EUA, o qual visava a transferência da resistência ao frio apresentada pelo trifoliata às principais cultivares copas. Desse trabalho, surgiram dezenas de híbridos -- citranges, citrumelos, citrandarins, citradias, citremons e citrumquats -- alguns dos quais vieram a se tornar porta-enxertos comerciais em diversos países, inclusive no Brasil. Naquela época, não havia nenhum problema sério relacionado com porta-enxertos, porque a quase totalidade dos pomares era formada por plantas originadas de sementes.

Um programa de melhoramento também foi implementado na Califórnia, no início do século $\mathrm{XX}$ e desenvolvido por várias décadas por H.B Frost. Eles deram origem, entre outros, aos citranges C-32 e C-35, ambos híbridos de trifoliata Webber-Fawcett com laranja Ruby (ROOSE, 1990).

$\mathrm{Na}$ ilha de Java, por volta de 1920, trabalhos conduzidos por H. J. Toxopeus, resultaram na seleção de porta-enxertos resistentes à gomose de Phytophthora (CAMERON \& FROST, 1968).

Ao longo do século passado, diversos países, com destaque para os Estados Unidos e a Espanha, iniciaram programas de melhoramento de porta-enxertos utilizando hibridação controlada e, mais recentemente, a fusão 
de protoplastos e a transgenia (GROSSER \& CHANDLER, 2002; FORNER et al.; 2003).

Nos Estados Unidos já estão em uso comercial os citrumelos F805, F80-8 e F80-3 e os citrandarins Changsha x English Large (US-815) e Sunki $x$ Benecke (US-812). Na Espanha, quatro híbridos já foram liberados para uso: citrandarins Cleópatra $x$ Trifoliata (F\&A-5) e (F\&A-13), King x Trifoliata (F\&A517) e o híbrido citrange Troyer $x$ Tangerina comum (F\&A-418)

No Brasil, os estudos visando melhoramento de porta-enxertos foram iniciados por volta de 1920 e até a década passada baseados essencialmente na seleção varietal ou clonal de variedades importadas. Um deles, iniciado em 1948, permitiu determinar a tolerância à tristeza de 400 citros e afins, introduzidos na quase totalidade dos Estados Unidos (GRANT et al., 1961), e incorporados ao Banco de Germoplasma de Citros do Instituto Agronômico. Posteriormente, quase três centenas de outras introduções, do Brasil e do exterior, foram incluídas nesse acervo. Esse germoplasma vem sendo utilizado em São Paulo e em outros estados e países para estudos concernentes a porta-enxertos, tendo gerado a publicação de dezenas de artigos.

Ao que parece, foi Carlos M. M. Dornelles, o pioneiro na produção de híbridos, quando na Estação Experimental de Taquari, RS, criou dezenas de citranges pela polinização de laranjeiras [C. sinensis (L.) Osb.] 'Pêra' ou 'Valência'. Dentre eles destacaram-se o C-13 e o C-37, descendentes da laranja 'Pêra', tolerantes à tristeza e resistentes à gomose de Phytophthora (PORTO \& SOUZA, 1984).

Em 1974, na Faculdade de Ciências Agrárias e VeterináriasUnesp, foram produzidos híbridos de tangerina 'Satsuma' (C. unshiu Marcow.) a princípio visando à obtenção de variedades produtoras de frutos de maturação precoce e resistentes ao cancro cítrico, os quais também vem sendo avaliados como porta-enxertos (DONADIO et al., 2001). 
A partir de 1990 diversas entidades iniciaram a produção de portaenxertos. Na Escola Superior de Agricultura "Luiz de Queiroz" - USP, foram realizadas fusões de protoplastos, almejando a obtenção de híbridos de limão 'Cravo' e de limão 'Volkameriano' resistentes ao declínio e a MSC (MOURÃO \& MENDES, 2002).

No Centro de Energia Nuclear na Agricultura-USP, foram criados, também por fusão de protoplastos, híbridos de tangerina 'Cleópatra' com limão ‘Cravo' ou laranja 'Caipira' (LATADO et al., 2002).

No Instituto Agronômico, a polinização controlada produziu híbridos entre limão 'Cravo', laranja 'Azeda', tangerina 'Sunki' e trifoliata. Enxertados com laranja 'Valência', 396 mostraram-se tolerantes à tristeza, 100 induziram maior produção de frutos que a tangerina 'Sunki' e 47 mais que o limão 'Cravo' (BORDIGNON et al., 2003).

$\mathrm{Na}$ Embrapa-Mandioca e Fruticultura, produziram-se portaenxertos por hibridação e fusão de protoplastos a partir dos limões 'Cravo' e 'Volkameriano', laranja doce, laranja 'Azeda', tangerinas 'Cleópatra' e 'Sunki' e trifoliata (SOARES FILHO et al., 2002).

No Centro APTA Citros "Sylvio Moreira", através de polinização controlada, foram produzidos híbridos entre limão 'Cravo', laranja 'Caipira', laranja 'Azeda', tangerina 'Sunki' e trifoliata 'Rubidoux' (CRISTOFANI et al., 1997).

A Agrocitros Citrolima Ltda, em Santa Cruz das Palmeiras (SP), criou híbridos a partir dos limões 'Cravo' e 'Volkameriano', laranjas 'Valência' e 'Azeda', trifoliata 'Flying Dragon' [P. trifoliata (L.) Raf. var. monstrosa], citrange 'Carrizo', citrumelo 'Swingle', tangerina 'Sunki' e tangelo 'Orlando' (C. reticulata Blanco x C. paradisi Macf.).

A maior parte desse germoplasma está em fase inicial de avaliação de seu comportamento na presença dos agentes limitantes às plantas 
cítricas. Esses trabalhos permitirão reduzir a indesejável dependência da introdução de germoplasma do exterior, quase sempre sujeita a boa vontade de pesquisadores e instituições e potencialmente introdutora de novas pragas e doenças.

\subsection{Características dos parentais dos porta-enxertos envolvidos neste trabalho e de alguns de seus híbridos}

São escassas as informações referentes à produção, características dos frutos, tamanho de plantas e tolerância a doenças e pragas envolvendo citrandarins (híbridos de trifoliata com microtangerinas) e outros híbridos de trifoliata, por constituírem uma nova geração de porta-enxertos. Nesta seção são relatadas às principais características dos parentais e alguns de seus híbridos.

\section{Limão ‘Cravo' (Citrus limonia Osb.)}

É tolerante ao vírus da tristeza (COSTA et al., 1954; GRANT et al., 1961), mas mostra caneluras quando infectado por raças severas do vírus, como a variante Capão Bonito (MÜLLER et al., 1968). É suscetível aos viróides da xiloporose e exocorte (MOREIRA, 1938, 1954, 1955), ao declínio dos citros (BERETTA et al., 1986a) e à MSC (BASSANEZl et al., 2002).

Induz produção precoce, alta produção de frutos de regular qualidade, compatibilidade com as cultivares copas, média resistência ao frio, boa resistência à seca. Tem melhor comportamento quando plantado em solos arenosos e profundos. Nos argilosos, sua produtividade pode ser inferior à das tangerinas 'Cleópatra' e 'Sunki'. 
Os frutos do limão 'Cravo' possuem, em média, 12 sementes e amadurecem de março a maio.

Entre os híbridos de limão 'Cravo' merecem destaque:

O 'Rangpur x Troyer' (RxT), é um híbrido entre limão Cravo $x$ citrange 'Troyer' $\{C$. limonia Osb. $x$ [P. trifoliata (L.) Raf. $x$ C. sinensis (L.) Osb.] \}, produzido por J. R. Furr, na Estação Experimental de Índio, Califórnia (EUA), em 1953, e possui característica seminanicante.

É tolerante à tristeza, mas suscetível à exocorte, à xiloporose e ao "blight", e oferece média resistência à gomose de Phytophthora. É suscetível à salinidade e pouco resistente à geada. As variedades nele enxertadas iniciam a produção dois a três anos após o plantio. Induz a produção de frutos de qualidade pouco inferior aos obtidos sobre citrumelo 'Swingle' e citrange 'Carrizo', mas muito superior aos produzidos sobre limão 'Rugoso' (CASTLE et al., 1986).

Os citromônias, limão 'Cravo' x Trifoliata [C. limonia Osb. x $P$. trifoliata (L.) Raf.], seleções $A$ e $B$, mostraram-se tolerantes à tristeza e ao declínio e induziram à laranjeira 'Valência' produções de frutos e de sólidos solúveis 63 e $86 \%$ maiores que as obtidas com o trifoliata 'Davis A' (POMPEU JUNIOR et al., 2002a, b).

Tangerina 'Cleópatra' (Citrus reshni hort. ex Tan.)

É tolerante à tristeza, exocorte, xiloporose, declínio e a MSC (GRANT et al., 1961; BERETTA et al., 1986b, 1994; GIMENES-FERNANDES \& BASSANEZI, 2001 ) e também ao frio e a solos calcários (WUTSCHER et al., 1970; YOUNG, 1977). Apresenta média resistência à gomose de Phytophthora (FEICHTENBERGER et al., 1994).

As cultivares nela enxertadas iniciam a produção de frutos mais tardiamente que as enxertadas no limão 'Cravo' ou em outros porta-enxertos; a 
maturação dos frutos é mais tardia e os frutos, menores que os obtidos com outros porta-enxertos, porém maiores que os obtidos com outras tangerinas, e o suco é de ótima qualidade. O sistema radicular é bem desenvolvido e profundo, mas as plantas são suscetiveis à seca. Quando plantada em solos argilosos, induz produções de frutos próximas ou superiores às obtidas sobre o limão 'Cravo'.

A tangerineira 'Cleópatra' produz frutos com maturação de julho a setembro, que têm, em média, 14 sementes.

Tangerina 'Sunki' (Citrus sunki hort. ex Tan.)

É tolerante à tristeza e a xiloporose porém intolerante à exocorte (GRANT et al., 1961, OLSON et al., 1962). É suscetivel à gomose de Phytophthora (AGUILAR-VILDOSO \& POMPEU JUNIOR, 1997), e tolerante ao declínio (BERETTA et al., 1986b) e à MSC (BASSANEZl et al., 2002).

Quando plantada em solos argilosos, induz a produção de frutos e de sólidos solúveis semelhante ou superior às obtidas nas laranjeiras enxertadas em limão ‘Cravo' ou em tangerina 'Cleópatra'.

Os frutos da tangerineira 'Sunki' amadurecem de abril a maio e contêm, em média, três sementes.

Trifoliata [Poncirus trifoliata (L.) Raf.]

É suscetível à exocorte, tolerante à xiloporose e imune à tristeza (SALIBE \& MOREIRA, 1965). É resistente à gomose de Phytophthora (FEICHTENBERGER et al., 1978) e ao nematóide Tylenchulus semipenetrans Cobb, porém não ao Radopholus similis (O'BANNON \& FORD, 1977). Plantas enxertadas em trifoliatas são tolerantes a geadas e intolerantes a solos calcários e salinos (PEYNADO \& YOUNG, 1969), quando apresentam sintomas 
de deficiência de fósforo. O trifoliata, é suscetível ao declínio (BERETTA et al., 1988b) e tolerante a MSC (BASSANEZI et al., 2003).

De modo geral, o trifoliata e seus híbridos induzem às copas a produção de frutos com melhores características comerciais que as obtidas sobre outros porta-enxertos (BORDIGNON et al., 2003). A maturação dos frutos é mais tardia que a proporcionada pelo limão 'Cravo'.

Os frutos de trifoliata amadurecem de março a maio e apresentam, em média, 38 sementes.

É considerado um porta-enxerto com "potencial ananicante" que pode se expressar com maior ou menor intensidade, dependendo de condições edafoclimáticas, da variedade copa, presença de viroses e uso da irrigação.

Citranges 'Troyer' e 'Carrizo' $\{[$ Poncirus trifoliata (L.) Raf]. $x$ [Citrus sinensis (L.) Osb. cv. Washington navel]\}.

São fenotipicamente idênticos, indistinguíveis por testes moleculares (COLETTA FILHO et al., 2004), confirmando suposições de que são a mesma seleção originada de um mesmo embrião zigótico. Outros autores os consideram plântulas diferentes originadas de sementes resultantes da mesma polinização realizada em 1909 (SAVAGE \& GARDNER, 1965). São semelhantes quanto as suas características agronômicas: crescimento, produção e qualidade dos frutos. São tolerantes à tristeza (GRANT et al.,1961) e à xiloporose (SALIBE \& MOREIRA, 1965) mas suscetíveis à exocorte (SALIBE, 1969) e ao declínio (BERETTA et al.,1994). São menos resistentes que o trifoliata à gomose de Phytophthora (FEICHTENBERGER et al., 1994), ao nematóide dos citros e ao $R$. similis (O'BANNON \& FORD, 1977). Não é conhecido o comportamento dos citranges 'Troyer' e 'Carrizo' na presença da morte súbita dos citros. São pouco tolerantes a solos salinos e calcários e mostram com freqüência deficiências de zinco e manganês (STANNARD, 
1975). De modo geral, induzem a formação de plantas menores que as formadas sobre limão 'Cravo'. Seus frutos amadurecem em abril-maio e têm, em média, 15 sementes com alta embrionia nucelar.

\section{Citrandarins}

Híbridos de microtangerinas (mandarinas) com trifoliatas, constituem uma nova geração de porta-enxertos que pretende reunir as qualidades das tangerinas, como tolerância à tristeza, ao declínio, ao viróide da exocorte e a solos calcários, às dos trifoliatas, entre elas a imunidade à tristeza, resistência à gomose e ao frio, bem como a indução de plantas de pequeno tamanho com elevadas produções por metro cúbico das copas de frutos de excelente qualidade. Como na maioria dos paises citrícolas a irrigação é pratica cultural rotineira, a tolerância à seca não é um atributo exigido dos portaenxertos.

Já estão em uso comercial diversos citrandarins:

X-639 [Citrus reshni hort. ex Tan. x Poncirus trifoliata (L.) Raf.]

Também conhecido por Nelspruit 639, é híbrido de trifoliata com tangerina 'Cleópatra' criado na África do Sul. É tolerante à tristeza e medianamente resistente à gomose (BROADBENT \& GOLLNOW, 1994). Induz a formação de plantas de tamanho médio, tolerantes ao frio, produtivas de frutos de boa qualidade com maturação precoce à meia-estação (RABE et al., 1993). 
F\&A (Forner\&Alcaide)

$\mathrm{Na}$ Espanha foram criados centenas de híbridos, dos quais quatro foram liberados para uso comercial. Segundo FORNER \& FORNER-GUINER (2002) são os seguintes:

O citrandarin 'Forner\&Alcaide 5' (F\&A-5) é resultado do cruzamento da tangerina 'Cleópatra' com o trifoliata. É resistente à tristeza e ao nematóide dos citros, tem boa tolerância a clorose férrica e ao encharcamento. Proporciona plantas semi-nanicas e frutos de boa qualidade.

O 'F\&A-13' possui os mesmos parentais que o 'F\&A-5', é resistente à tristeza e ao encharcamento. É suscetível a clorose férrica e ao nematóide dos citros. É um porta-enxerto semi-nanicante que induz a produção de frutos de alta qualidade.

O 'F\&A- 517' é um híbrido de tangerina King $x$ Trifoliata [C. nobilis Loureiro. x P. trifoliata (L.) Raf.]. É tolerante à tristeza e a clorose férrica , resistente ao nematóide dos citros. Induz a formação de plantas nanicas, muito produtivas e frutos de boa qualidade.

Já o híbrido 'F\&A-418', resultante do cruzamento do citrange 'Troyer' com tangerina comum, é ananicante, tolerante à tristeza mas, suscetível ao nematóide dos citros. Induz a produção de frutos grandes e de alta qualidade.

\section{'Changsha x English Small', 'Changsha x English Large' e 'Sunki $x$ Benecke'}

Parte dos citrandarins desenvolvidos por J. R. Furr, na Califórnia, foram avaliados em São Paulo. Os resultados mostram que os mais promissores são o 'Changsha x English Small' e o 'Sunki x Benecke'. Seus frutos amadurecem de março a maio e têm, em média, 15 sementes. Ambos são tolerantes à tristeza e ao declínio e apresentam boa resistência à gomose 
de Phytophthora e ao nematóide dos citros. Induziram à laranjeira 'Valência' produções de frutos 152 e $79 \%$ e de sólidos solúveis 176 e 105\%, respectivamente, maiores que as obtidas com o trifoliata 'Davis A' (POMPEU JUNIOR et al., 2002a,b). O citrandarin 'Sunki x Benecke' passou a ser recomendado na Flórida a partir de 2001, sob a sigla US-812 (BOWMAN, 2003).

Nesse mesmo experimento, o citrandarin 'Changsha $x$ English Large' superou em $48 \%$ a produção de frutos e em $68 \%$ a de sólidos solúveis obtidas com o trifoliata 'Davis A'. É tolerante à tristeza e ao declínio, resistente à gomose de Phytophthora e ao nematóide dos citros. Tem o inconveniente de possuir poucas sementes viáveis e alta proporção de plântulas fora do padrão. Seu uso passou a ser recomendado na Flórida a partir de 1999, sob a sigla US852 (BOWMAN, 2003).

Em experimento de porta-enxertos para a laranjeira 'Homosassa', após 8 anos de avaliações, a maior produtividade média, 36 toneladas por hectare, foi obtida pelo citrandarin Sunki x English. Esta produtividade foi $15 \%$ superior as obtidas com as tangerinas 'Sunki' e 'Cleópatra' (RELATÓRIO DE ATIVIDADES, 2003).

\subsection{Fatores a serem considerados na escolha de porta-enxertos}

Características de essencialidade ou de desejabilidade de portaenxertos são aspectos particulares de cada país ou região que será utilizado. Para as condições brasileiras e, mais específicas, para o Estado de São Paulo, podemos classificar como essenciais: tolerância ao vírus da tristeza, a MSC e à gomose de Phytophthora, além de induzir boa produção e qualidade dos frutos; como características desejáveis: tolerância ao declínio dos citros, resistência à 
seca, compatibilidade com as principais variedades copa, elevado número de sementes e poliembrionia nucelar e poder ananicante; como caráter de menor importância: tolerância ao frio.

\subsubsection{Tolerância à tristeza dos citros}

A tristeza é causada por um complexo virótico exclusivo do floema e transmitido por borbulha e pelo pulgão preto.

Os sintomas da doença são pouco específicos, assemelhando-se àqueles causados por um sistema radicular pouco ativo. Inicialmente as folhas perdem o brilho, passam a apresentar deficiências nutricionais e caem. Concomitantemente, há seca dos ramos a partir das extremidades e os frutos paralisam seu desenvolvimento. As plantas definham e morrem em período variável de semanas a alguns anos.

Existem vários complexos do vírus que podem causar diferentes sintomas nas plantas. Um tipo de sintoma associado à interação copa-portaenxerto é o que ocorre em plantas enxertadas em porta-enxertos intolerantes como a laranja 'Azeda'. Dependendo do complexo, a planta sofre um declínio rápido e morre em poucas semanas (CRISTOFANI, 1997).

Outro complexo denominado Capão Bonito, causa caneluras em porta-enxertos tolerantes a outras raças do vírus, como o limão 'Cravo' e as tangerinas 'Cleópatra' e 'Oneco' (C. reticulata Blanco) e o trifoliata. A tangerina 'Sunki' vem-se mostrando tolerante a essa estirpe de tristeza (MÜLLER et al, 1968). 


\subsubsection{Resistência ao declínio dos citros}

O declínio das plantas cítricas foi detectado em 1977, no Estado de São Paulo, afetando laranjeiras enxertadas em limão 'Cravo' (RODRIGUEZ et al., 1979) e, posteriormente em limão 'Volkameriano', trifoliata, citranges 'Troyer' e 'Carrizo' e outros porta-enxertos (BERETTA et al., 1986a, 1986b, 1994). É similar ao "blight" que ocorre na Flórida desde 1880, ao "declinamiento" ou "fruta bolita" na Argentina, "marchitamiento repentino" no Uruguai e "declinamento" na África do Sul (WUTSCHER et al., 1980; BERETTA et al., 1994, CARLOS, 1996). De causas ainda desconhecidas, foi transmitido por encostia das raízes (CARLOS, 1996).

Os sintomas geralmente se manifestam nas laranjeiras com quatro ou mais anos de idade, não sendo observados em tangerineiras, limeiras ácidas e pomeleiros enxertados sobre porta-enxertos suscetíveis. Seu controle é feito com o emprego de porta-enxertos menos suscetíveis como o citrumelo 'Swingle', a laranja 'Caipira' e as tangerinas 'Cleópatra' e 'Sunki', embora laranjeiras 'Valência' enxertadas sobre tangerina 'Cleópatra', com 14 anos de idade, tenham manifestado sintomas da doença (MÜLLER et al., 1997). Não há relatos no Brasil de laranjeiras sobre a tangerineira 'Sunki' afetadas por declínio.

Os sintomas do declínio ocorrem num setor da copa evoluindo para toda a planta. As folhas tornam-se opacas, levemente torcidas e às vezes ocorre deficiência de zinco. Ocorrem florescimentos aleatórios, seca dos ponteiros, é freqüente a emissão de ramos ladrões na parte interna da copa. Os frutos são miúdos, amarelo-pálido, em número reduzido. Após alguns anos a planta apresenta-se definhada, improdutiva, mas geralmente não morre. Esses sintomas possuem caráter não específico, ou seja, ocorrem também, de certa maneira, em outras anomalias. 
As observações indicam que todos os porta-enxertos comerciais apresentam suscetibilidade ao "blight"/declínio, que se manifesta com o envelhecimento da planta. Assim, CASTLE (1993) relata que, em experimento de porta-enxertos para laranja 'Valência' com 15 anos de idade, o "blight" foi responsável pela perda de $45 \%$ das plantas enxertadas em limão 'Volkameriano', 43\% das enxertadas em limão 'Rugoso', 27\% das enxertadas em limão 'Cravo', 23\% daquelas sobre tangelo 'Orlando', 17\% das plantas sobre trifoliata, $13 \%$ das enxertadas sobre citrange 'Carrizo', $7 \%$ das enxertadas em citrumelo 'Swingle' e $2 \%$ das plantas sobre laranja doce. Apenas as enxertadas sobre laranja 'Azeda' não apresentaram plantas mortas. Relata ainda que a perda de laranjeiras 'Valência' enxertadas sobre tangerina 'Cleópatra' que havia sido de $15 \%$ até as plantas terem 12 anos de idade, aumentou para $23 \%$ quando elas completaram 15 anos, ou seja, um crescimento de $8 \%$ em três anos.

Informações sobre tolerância ao declínio dos citros em citrandarins foram verificados nos trabalhos desenvolvidos por POMPEU JUNIOR et al., (2002a, b) que verificaram a tolerância dos citrandarins 'Changsha x English Small', 'Changsha x English Large' e 'Sunki x Benecke' à doença.

A descoberta, na Flórida, de proteínas, em especial a proteína 12 $\mathrm{kD}$, associadas à anomalia, permitiu o diagnóstico precoce, porém sem evidenciar o envolvimento de algum patógeno. Segundo, DERRICK et al., 1990, a margem de erro é pequena, quando associamos a presença da proteína como precursora da ocorrência do "blight".

No Brasil, estudos desenvolvidos por CARLOS (1996) evidenciaram outras proteínas associadas ao declínio, passíveis de serem utilizadas de forma preditiva antecedendo o aparecimento dos sintomas no campo. A utilização dessas proteínas vem suprir as deficiências apresentadas pelo teste de injeção de água no tronco, onde alguns autores, atribuem melhor 
desempenho dos resultados quando os sintomas visuais já estão presentes (LEE et al., citado por CARLOS, 1996).

\subsubsection{Tolerância à morte súbita dos citros}

Constatada em 1999, essa anomalia vem afetando laranjeiras e tangerineiras enxertadas em limão 'Cravo' (GIMENES-FERNANDES \& BASSANEZI, 2001) e em limão 'Volkameriano' (BASSANEZI et al., 2003). As plantas apresentam, inicialmente, folhas verde-pálido seguida da queda das folhas e morte dos ramos apicais e culminando com o perecimento das plantas, cerca de seis meses após o aparecimento dos sintomas (MÜLLER et al., 2002). A retirada da casca do porta-enxerto suscetível, revela, na região cambial, um amarelecimento, possivelmente devido a oxidação do tecido, sendo esse o sintoma-diagnóstico da doença e que precede os sintomas da copa. A MSC já foi observada em plantas com dois anos de idade, sendo mais freqüente nas com mais de seis anos. Plantas enxertadas sobre tangerinas 'Cleópatra' e 'Sunki', citrumelo 'Swingle' e trifoliata não mostram sintomas da doença.

Suas causas permanecem desconhecidas, havendo evidências de que seja provocada por vírus, transmitido por borbulha e por vetor alado (YAMAMOTO et al., 2003). A convivência com a MSC vem sendo feita pela subenxertia com porta-enxertos tolerantes e pelo plantio de mudas formadas sobre esses porta-enxertos.

Os porta-enxertos participantes do presente trabalho estão sendo avaliados quanto ao seu comportamento na presença da MSC em áreas onde foram erradicados pomares afetados por essa doença. 


\subsubsection{Resistência à gomose de Phytophthora}

A primeira ocorrência documentada da gomose de Phytophthora no Brasil data de 1917 (ALENCAR, 1941) e ela pode ser considerada a principal doença fúngica dos porta-enxertos de citros. O grau de resistência ou tolerância do porta-enxerto a essa doença é extremamente importante, motivo pelo qual é um dos critérios de seleção num programa de melhoramento. Das onze espécies de Phytophthora relatadas em associação com citros, cinco foram encontradas na América do Sul e apenas duas, P. citrophthora (R.E. Sm. e E.H. Sm.) e a $P$. parasítica Dastur ( $P$. nicotianae Breda de Haan), são as principais causadoras da gomose no Brasil, sendo a esta a maior responsável pela perda de plantas em pomares e viveiros no Estado de São Paulo (FEITCHERBENGER, 2001).

As lesões por ela provocadas podem causar o anelamento das raízes e do tronco, impedindo o fluxo da seiva elaborada das folhas para as raízes, ocasionando a morte destas. Em conseqüência, ocorre a descoloração das nervuras e amarelecimento das folhas, que murcham e secam, florescimentos e frutificações freqüentes e extemporâneos, produção de frutos pequenos e de maturação precoce, desfolha e seca de ramos e morte da planta.

Segundo CHIACCHIO \& GALLI (1978), as lesões causadas por $P$. parasítica são mais prejudiciais às plantas que as causadas por $P$. citrophthora por serem mais largas e atingirem maior número de elementos de vaso ocasionando o anelamento do tronco e posterior morte da planta.

As estratégias de controle devem se iniciar pelo plantio de mudas sadias, evitar o plantio em áreas infestadas por período aproximado de quatro anos, devido as estruturas de resistência do patógeno permanecerem no solo e evitar áreas com excesso de umidade além do controle cultural e químico. $\mathrm{O}$ uso de porta-enxertos resistentes é o método mais econômico e eficiente. 
De maneira geral os porta-enxertos podem ser agrupados quanto à suscetibilidade às infecções do tronco por $P$. citrophthora e $P$. parasitica em: alta suscetibilidade: laranjas doces e limões 'Rugosos'; moderada suscetibilidade: limões 'Cravo' e 'Volkameriano', tangerinas 'Sunki' e 'Cleópatra', tangelo 'Orlando' e citranges 'Troyer' e 'Carrizo'; baixa suscetibilidade: Iaranja 'Azeda' e C. macrophylla, e muito baixa suscetibilidade: trifoliata e citrumelo 'Swingle' (FEICHTENBERGER et al., 1994). Essas reações podem ser alteradas por ferimentos causados por agentes abióticos, como grades e herbicidas, ou bióticos, como larvas de besouros. Na Flórida, a ação conjunta da Diaprepes abbreviatus (L.) (Coleóptera: Curculionidae) com Phytophthora spp. vem ampliando a perda de plantas enxertadas sobre portaenxertos considerados resistentes à gomose (GRAHAM, 2003).

Testes realizados para determinar a resistência dos porta-enxertos a Phytophthora tem-se mostrado conflitantes. Embora fatores ambientais e do hospedeiro possam influenciar o desenvolvimento da doença, seus efeitos e magnitudes estão longe de serem bem quantificados.

As divergências entre os resultados podem estar na forma da avaliação das lesões (altura, comprimento ou área), na virulência da estirpe, além do método de inoculação utilizado. SIVIERO (2001) estudando diversos métodos de inoculação de Phytophthora, como método do disco, do palito e da agulha infectada, verificou que este último foi o mais apropriado para inoculação em genótipos jovens.

GRIMM \& HUTCHISON (1977) verificaram que a resistência à $P$ parasítica variou de forma crescente para limão 'Cravo', trifoliata 'Rubidoux', citrange 'Carrizo' e nos citrandarins Cleópatra x Christiansen, Cleópatra $x$ English, Cleópatra x Rubidoux e Cleópatra x Swingle.

Estudando a resistência de quinze clones de trifoliata à gomose de Phytophthora, após 62 dias da inoculação, FEITCHTENBERGER et al., (1978), detectaram, pela comparação da área lesionada, que o trifoliata 'Rubidoux' foi 
altamente resistente e o clone 'Christian' apresentou resistência intermediária à gomose.

CARVALHO (2000) relata que híbridos de tangerina 'Sunki' e $P$. trifoliata e seus recíprocos foram os mais promissores para resistência a $P$. parasítica.

Os citrandarins 'Changsha x English Small', 'Changsha x English Large' e 'Sunki x Benecke'. apresentaram boa resistência à gomose de Phytophthora (POMPEU JUNIOR et al., 2002a, b).

HUTCHISON citado por BROADBENT \& GOLLNOW (1994), relata que a resistência à gomose de Phytophthora é controlada por diversos genes o que pode explicar a diversidade de resistência de híbridos de mesmo parentais. Esses autores verificaram que citrandarins de mesmo parentais (Scarlet $\mathrm{x}$ Trifoliata) apresentavam valores antagônicos de resistência à gomose de $P$. citrophthora. Já BOAVA et al. (2003) não constataram diferenças significativas entre híbridos de trifoliata de mesmo parentais quanto a resistência à gomose de $P$. parasítica.

\subsubsection{Influência dos porta-enxertos no tamanho das plantas}

De modo geral, a produção das plantas cítricas é proporcional ao tamanho da copa porém, as plantas nanicas, via de regra, produzem maior quantidade de frutos por metro cúbico de copa e permitem elevadas densidades de plantio e, em conseqüência, possibilitam maior produção por área (MENDEL, 1956). A menor altura das plantas aumenta a eficiência da inspeção e controle de doenças e pragas, reduz os custos e aumenta a segurança das colheitas. Entre os métodos utilizados para a redução do tamanho das plantas estão o emprego de porta-enxertos nanicantes ou seminanicantes e o uso de 
interenxertos. São interessantes porque não envolvem o uso de podas periódicas ou de viróides ananicantes, de distribuição irregular nas plantas matrizes, podendo não estar presente em todas as borbulhas utilizadas para a formação das mudas, além de apresentar, na mesma planta, complexos de diferentes virulências, passiveis de sofrerem mutações.

Seleções de trifoliata e alguns de seus híbridos, apresentam um "potencial ananicante" que pode se expressar com maior ou menor intensidade dependendo das condições edafoclimáticas, da variedade copa, presença de viroses e do uso da irrigação. Mesmo quando enxertados com borbulhas de clones nucelares eles induzem a formação de plantas vigorosas porém sempre menores que as obtidas com outros porta-enxertos e que podem ser consideradas como semi-nanicas (SHANON et al., 1960; BITTERS et al., 1973; POMPEU JUNIOR et al., 2002c).

Dentre os híbridos de trifoliata com "poder ananicante" destacamse as citradias [( $P$. trifoliata (L.) Raf. $\mathrm{x}$ C. aurantium (L.)] e os citrandarins (CASTLE et al., 1986; RABE et al., 1993; FORNER \& FORNER-GINER, 2002; POMPEU JUNIOR, 2001).

Somente o trifoliata Flying Dragon $[P$. trifoliata var. monstrosa $(\mathrm{T}$. Ito) Swingle] é considerado um porta-enxerto geneticamente nanicante, porque possibilita a formação de plantas com altura inferior a $2,5 \mathrm{~m}$ em todos os países onde vem sendo avaliado. Ele vem sendo investigado desde 1972 na Califórnia, onde laranjeiras 'Valência' com 14 anos de idade apresentavam altura de 1,9 m e produção media de $33 \mathrm{~kg}$ de frutos de alta qualidade por planta. A lima ácida 'Tahiti' [( C. latifólia (Yu. Tan.) Tan.] sobre Flying Dragon apresentou copa 54\% menor que a enxertada no trifoliata 'Pomeroy' e $70 \%$ menor que a enxertada em C. macrophylla (ROOSE, 1986).

Em São Paulo, a viabilidade do uso de altas densidades no plantio de laranjeiras 'Valência' enxertadas em trifoliata, sem o uso da irrigação, foi 
demonstrada por RODRIGUEZ (1972) e TEÓFILO SOBRINHO et al., (1992, 1995).

O mecanismo indutor do nanismo é ainda desconhecido, mas parece estar relacionado com o grau de afinidade entre copa e porta-enxerto.

\subsubsection{Embrionia nucelar e poliembrionia}

A dispersão dos citros pelo mundo e a fixação de suas características foi possível devido ao fenômeno da embrionia nucelar (produção de embriões idênticos a planta-mãe). A embrionia nucelar permite a perpetuação dos caracteres desejáveis de uma determinada variedade cítrica.

Segundo HARTMANN \& KESTER (1968) a embrionia nucelar constitui uma forma de apomixia, cujos embriões são originados de uma ou mais células da nucela. Já a poliembrionia, por definição, refere-se à formação de dois ou mais embriões na semente, independente de sua origem sexual ou não.

O tamanho e o número de embriões zigóticos e nucelares contidos numa semente, é influenciado pela variedade, nutrição da planta, fatores ambientais e variedade polinizadora. (MOREIRA et al., 1947; SALIBE \& CEREDA, 1970; OGATA et al., 1981). Mesmo em sementes altamente poliembrionicas, apenas 3 a 4 embriões chegam a germinar. (SALIBE \& CEREDA, 1970; OGATA et al., 1981). A competição por nutrientes dentro da semente, faz com que os embriões de menor tamanho e os topograficamente desfavorecidos não germinem.

As sementes cítricas, segundo GURGEL (1952), apresentam geralmente um embrião sexual e embriões apogâmicos provenientes do desenvolvimento das células do nucelo. A proporção de embriões zigóticos e 
nucelares varia grandemente entre as espécies cítricas. Algumas produzem apenas o embrião zigótico como as toranjas [C. grandis (L.) Osb.] classificadas como monoembriônicas. Raramente ocorre a formação de mais de um embrião sexuado, a não ser que ocorra o desenvolvimento de dois sacos embrionários, a ocorrência de mais de uma oosfera por saco embrionário ou, ainda, a clivagem do zigoto.

Esses fatores, associados aos métodos, desenvolvidos por MOREIRA et al. (1947), para a determinação do número de embriões por semente e porcentagem de poliembrionia, quer seja ele direto: contagem dos embriões na semente, ou indireto: baseado na germinação das sementes, podem estar relacionados aos valores díspares encontrados na literatura para determinada variedade cítrica.

Como exemplo, MOREIRA et al. (1947), verificaram que o número médio de embriões e a porcentagem de poliembrionia nas sementes do limão 'Cravo' obtidos pelo método indireto era de 1,1 e 7,9\% enquanto que pelo método direto esses valores aumentaram para 1,7 e $49,6 \%$.

PIO \& POMPEU JUNIOR (1984), encontraram para as seleções de trifoliata 'Christian' e 'Rubidoux', através do método indireto, número médio de embriões por semente de 1,14 e 1,08 e porcentagem de poliembrionia de 16 e $8 \%$ respectivamente.

SOARES FILHO et al. (2000) constatou na tangerina 'Sunki' número médio de embriões por semente de 1,3 e poliembrionia de 15,9\%. Já a tangerina 'Cleópatra' apresentou 1,68 embrião/semente e poliembrionia de $11,60 \%$ nos trabalhos desenvolvidos por OGATA et al. (1981)

PRASAD \& RAVISHNKAS (1982) avaliaram 15 seleções de limão 'Cravo' e encontraram desde uma seleção monoembriônica (Flórida) até indivíduos com media de 1,9 embrião por semente (seleções Poona e Austrália). 
Ainda são escassas as informações referentes a embrionia nucelar e a poliembrionia dos citrandarins. FORNER \& FORNER-GUINER (2002) relataram ampla variabilidade da porcentagem de poliembrionia nas sementes dos híbridos F\&A criados por Forner \& Alcaide, apresentando desde sementes monoembriônicas até $100 \%$ de poliembrionia.

A produção de porta-enxertos cítricos por semente é viável devido à ocorrência de embriões nucelares e ao fenômeno da poliembrionia motivo pelo qual também é um dos critérios de seleção no programa de melhoramento.

\subsubsection{Incompatibilidade entre copa e porta-enxerto}

A enxertia possibilita o contato de vegetais geneticamente diferentes e com sistemas fisiológicos, bioquímicos e anatômicos distintos permitindo assim interações favoráveis como desfavoráveis. Dentre estas, destaca-se a ocorrência de pouca afinidade e até incompatibilidade entre copas e porta-enxertos.

Até o momento não são conhecidas as causas da incompatibilidade que ocorre nas plantas. Uma das hipóteses afirma que ela está associada a diferenças no vigor e no início e término do ciclo vegetativo do porta-enxerto e do enxerto. Outras atribuem-na a diferenças fisiológicas e bioquímicas, através de substâncias preexistentes ou formadas na região da enxertia. Alguns autores associam-na a fatores, provavelmente vírus, transmissíveis por borbulhas (BRIDGES \& YOUTSEY, 1968; MCCLEAN, 1974; ROISTACHER, 1991). Os fatores ambientais exercem influência na expressão ou não da anomalia, o que poderia explicar a não visualização dos sintomas em determinadas situações. 
A incompatibilidade pode ser definida como um fenômeno de senescência prematura causada por processos fisiológicos e bioquímicos (FEUCHT, 1988) e que pode ser intensificado sob condições de estresse (FEUCHT \& SCHMID, 1988).

Nas plantas cítricas os sintomas de incompatibilidade são caracterizados por deficiências nutricionais, queda das folhas, seca de ponteiros, brotação exagerada do porta-enxerto e produções não econômicas de frutos, podendo vir a morrer. Retirada a casca na região da enxertia observase penetração da casca no lenho em parte ou em toda a circunferência do tronco quase sempre acompanhado pela formação de goma tanto na casca quanto no lenho (NAURIYAL et al., 1958; KIRKPATRICK et al., 1962; POMPEU JUNIOR et al., 1972).

No Brasil, as incompatibilidades mais importantes são as das laranjas 'Pêra' e 'Seleta de Itaboraí' enxertadas em limão 'Rugoso da Flórida' (C. jambhiri Lush.) e trifoliata 'Limeira' (POMPEU JÚNIOR et al., 1972). Mais recentemente foi constatada incompatibilidade da laranja 'Pêra' com o limão 'Rugoso da África' (C. jambhiri Lush.) (POMPEU JÚNIOR, 1996) e com o citrumelo 'Swingle' (POMPEU JÚNIOR, 1991), e dos clones 'Pêra premunizada' e 'Pêra Bianchi' com o citrumelo 'Swingle' e da 'Pêra premunizada' com os citrumelos 'F80-3' e 'F80-5' (POMPEU JÚNIOR, 2000; POMPEU JUNIOR \& BLUMER, 2002b).

Laranjeiras 'Valência', com 14 anos de idade, passaram a apresentar sintomas de incompatibilidade quando enxertadas no trangpur Cravo x Carrizo (POMPEU JUNIOR \& BLUMER, 2002a).

Estudos conduzidos com o limão 'Eureka' enxertado em seleções de trifoliata mostraram que as seleções consideradas nanicantes não apresentaram sintomas de incompatibilidade os quais foram constatados nos limoeiros formados sobre as seleções mais vigorosas (NAURIYAL et al, 1958). 
Cabe ressaltar que o maior diâmetro do tronco do porta-enxerto em relação ao da copa ou vice-versa nem sempre é indicativo de incompatibilidade. Diversos cultivares de citros enxertados sobre trifoliatas e seus híbridos mostram maior diâmetro do caule do porta-enxerto em relação ao da copa, porém as plantas não apresentam anel de goma e são produtivas e longevas.

Nas plantas cítricas as incompatibilidades podem ser superadas pelo uso de interenxertos, compatíveis com copa e porta-enxerto, inseridos por ocasião da formação da muda. Porém tal processo aumenta o custo final da muda. 


\section{MATERIAL E MÉTODOS}

\section{1 Área experimental}

O experimento foi instalado dentro de pomar comercial, na Fazenda Raio de Sol, no município de Itirapina, SP. O plantio foi realizado em fevereiro de 1988, no espaçamento $7,5 \mathrm{~m}$ x 4,2 $\mathrm{m}$ e tem como bordadura laranjeiras 'Pêra' enxertadas em tangerina 'Cleópatra'. O experimento foi conduzido sem irrigação.

O clima é classificado como Cwa (Setzer, 1966) e o solo é um Latossolo Vermelho-amarelo, textura arenosa. A Tabela 1 refere-se aos resultados das análises químicas do solo em 1991, 1995 e 2002.

Tabela 1. Resultados das análises químicas do solo em 1991, 1995 e 2002

\begin{tabular}{cccccccc}
\hline $\begin{array}{c}\text { Ano da } \\
\text { análise }\end{array}$ & $\begin{array}{c}\text { Prof. } \\
\text { amostra } \\
\mathrm{cm}\end{array}$ & $\begin{array}{c}\text { P-resina } \\
\mu \mathrm{gg.} \mathrm{cm}^{-3}\end{array}$ & $\mathrm{~K}$ & $\begin{array}{c}\mathrm{Ca} \\
\mathrm{mmol}_{\mathrm{c}} \cdot \mathrm{dm}^{-3}\end{array}$ & $\mathrm{Mg}$ & $\mathrm{V}$ & $\mathrm{M} . \mathrm{O}$. \\
\hline \multirow{2}{*}{1991} & $0-30$ & 21 & 0,5 & 21 & 7 & 72,2 & 1,3 \\
& $30-60$ & 6 & 0,5 & 9 & 3 & 53,2 & 1,0 \\
1995 & $0-20$ & 34 & 2,0 & 16 & 8 & 60,5 & 1,0 \\
& $20-60$ & 7 & 0,8 & 9 & 4 & 43,4 & 0,8 \\
2002 & $0-20$ & 75 & 0,8 & 47 & 12 & 78,0 & 1,1 \\
& $20-60$ & 20 & 0,4 & 13 & 5 & 51,0 & 0,7 \\
\hline
\end{tabular}




\subsection{Tratamentos e delineamento experimental}

Foram avaliados porta enxertos produzidos pelo Departament of Agriculture, Flórida, EUA, ainda inéditos no Brasil, em comparação com dois híbridos já consagrados na citricultura, os citranges 'Troyer' e 'Carrizo'. A Tabela 2 lista os porta-enxertos utilizados no experimento indicando além da numeração de introdução desses porta-enxertos no Banco de Germoplasma (BAG) do Centro APTA Citros "Sylvio Moreira", seu nome comum e seu nome específico.

Tabela 2. Numeração do porta-enxerto no BAG, seu nome comum e específico

\begin{tabular}{|c|c|c|}
\hline Acesso $\mathrm{n}^{\circ}{ }^{1}$ & Nome comum & Nome específico \\
\hline $385 \mathrm{CV}$ & Citrange 'Troyer' & Citrus sinensis $x$ Poncirus trifoliata \\
\hline $387 \mathrm{CV}$ & Citrange 'Carrizo' & C. sinensis $\times$ P. trifoliata \\
\hline $710 \mathrm{CN}$ & Citrandarin Cleópatra x English & C.reshni $x$ P. trifoliata \\
\hline $712 \mathrm{CN}$ & Citrandarin Cleópatra x Christian & C. reshni $\times$ P. trifoliata \\
\hline $715 \mathrm{CN}$ & Citrandarin Cleópatra x Swingle & C. reshni $\times$ P. trifoliata \\
\hline $717 \mathrm{CN}$ & Trangpur Cravo x Carrizo & C. limonia $\times(C$. sinensis $\times P$. trifoliata) \\
\hline 1.574 & Citrandarin Cleópatra x Trifoliata & C. reshni $\times$ P. trifoliata \\
\hline 1.587 & Citrandarin Cleópatra x Swingle & C. reshni $\times$ P. trifoliata \\
\hline 1.600 & Citrandarin Cleópatra x Rubidoux & C. reshni $\times$ P. trifoliata \\
\hline 1.614 & Citrandarin Cleópatra x Swingle & C. reshni $\times$ P. trifoliata \\
\hline 1.615 & Citrandarin Clementina x Trifoliata & C. clementina $\times$ P. trifoliata \\
\hline 1.628 & Citrandarin Sunki x English & C. sunki $x$ P. trifoliata \\
\hline 1.660 & Citrandarin Cleópatra x Rubidoux & C. reshni $\times$ P. trifoliata \\
\hline
\end{tabular}

${ }^{1}$ número no BAG-Citros do IAC. 
Como copa foi utilizada a laranja 'Valência' clone nucelar, que, em meados da década de 1980, era a terceira copa da citricultura paulista, com cerca de $8 \%$ das plantas, havendo indícios de crescente interesse pelo seu plantio (POMPEU JUNIOR, 2001). Em 2002-2004, ela foi a principal copa encontrada nos viveiros inspecionados pelo Fundecitrus, participando, em média, de 38\% das mudas (POMPEU JUNIOR et al., 2004). Outro fator seletivo foi a ausência de relatos de incompatibilidade da cultivar com outros portaenxertos exceto limão 'Rugoso' (BRIDGES \& YOUTSEY, 1968).

O delineamento estatístico utilizado foi de blocos ao acaso com uma planta por parcela e dez repetições.

\subsection{Avaliações}

\subsubsection{Produção de frutos}

Os porta-enxertos foram avaliados pelas produções anuais e total das cinco primeiras e pelo total das treze colheitas (1991-2003). A colheita dos frutos foi realizada em dezembro, obtendo-se a produção, em quilogramas por planta.

\subsubsection{Altura, diâmetro e volume das copas}

As avaliações foram realizadas em 2000, 2001 e 2004, com auxílio de régua graduada em centímetros. As dimensões foram tomadas do solo até o 
ápice da planta para a altura e paralela a linha do plantio, na altura da cintura do observador, para o diâmetro da copa.

Considerando que as copas das laranjeiras tinham a forma aproximada de uma semi-elipsóide, o seu volume foi calculado pela fórmula: $V=$ 2/3 $\pi R^{2} H$, onde $\mathrm{R}$ é o raio da copa e $\mathrm{H}$ a altura da planta (MENDEL, 1956).

\subsubsection{Eficiência produtiva das copas}

A eficiência produtiva traduz a capacidade da planta em aproveitar a sua arquitetura para produção de frutos. Os valores de eficiência produtiva foram obtidos pelo quociente das produções de 1999, 2000 e 2003 pelo volume das copas medidos em 2000, 2001 e 2004, e são expressos em quilogramas de frutos por metro cúbico de copa.

\subsubsection{Qualidade dos frutos}

Para análise da qualidade, foram coletadas amostras de frutos de três blocos em meados de outubro de 2001, 2002 e 2003. A amostra era constituída por 10 frutos coletados dois de cada quadrante da planta e dois internos a mesma. Foram determinados os seguintes caracteres físicos e químicos:

Massa do fruto: através da pesagem em balança com capacidade máxima para 15 quilos, graduada em grama e calculada a massa média por fruto.

Altura: utilizando canaleta graduada em centímetros onde os 10 frutos foram colocados justapostos (ápice-base) e posteriormente calculada a altura média. 
Diâmetro: na mesma canaleta, os 10 frutos foram colocados justapostos, pela região equatorial e calculado o diâmetro médio.

Índice de conformação (A/L): representa a razão entre a altura e o diâmetro, o qual preconiza o formato do fruto, que pode variar de oblongo $(A / L>1,0)$, esférico $(A / L=1,0)$ à achatado $(A / L<1,0)$.

Porcentagem de suco: determinado após o esmagamento da fruta em extratora OIC modelo OTTO 1800 (filtro: diâmetro interno $=26,11 \mathrm{~mm}$; comprimento $=$ $265 \mathrm{~mm}$; furos de diâmetro = 0,6 mm; área de vazão de 20\%).

Sólidos Solúveis Totais (SST): determinado por leitura em refratômetro B\&S mod. RFM 330, corrigido pela temperatura e pela acidez e expresso em graus Brix ( ${ }^{\circ}$ Brix).

Acidez: determinada pela titulação de $25 \mathrm{ml}$ do suco com NAOH, em solução $0,3125 \mathrm{~N}$ usando fenolftaleína como indicador, expressa em porcentagem (gramas de ácido cítrico por $100 \mathrm{ml}$ de suco).

Ratio: Foi obtido por cálculo, dividindo-se o teor de SST pela acidez titulada.

Sólidos solúveis por caixa : Também conhecido como Índice Tecnológico (IT), é a quantidade de SST, em quilograma por caixa. Calculado segundo (DI GIORGI et al., 1990) pela fórmula: IT = porcentagem de suco (\%) x sólidos solúveis totais ( ${ }^{\circ}$ Brix) $x$ peso da caixa padrão industrial de citros $(40,8 \mathrm{~kg}) / 10.000$.

\subsubsection{Tolerância à tristeza}

As laranjeiras foram avaliadas visualmente quanto à manifestação dos sintomas atribuídos a intolerância do porta-enxerto ao vírus da tristeza dos citros 


\subsubsection{Resistência ao declínio}

As plantas foram avaliadas visualmente quanto a manifestação dos sintomas de declínio, bem como foi utilizado o teste diagnóstico 'DIBA', visando detectar a proteína $12 \mathrm{kD}$, associada à ocorrência da doença mesmo antes do aparecimento dos sintomas no campo.

Para o teste foram avaliados os porta-enxertos de cinco blocos, totalizando 65 amostras, que representam $50 \%$ das plantas do experimento. As amostras eram compostas por 20 folhas coletadas ao redor da copa da planta. O teste diagnóstico foi realizado, na Seção de Bioquímica Fitopatológica do Instituto Biológico de São Paulo, pelo Dr. Ricardo Harakava.

Para a detecção da proteína, foram feitos, em 22/03/2004, extratos das 20 folhas de cada planta. Os extratos foram obtidos por esmagamento em triturador rotativo sendo posteriormente depositado um microlitro por amostra em membrana de nitrocelulose. A membrana foi incubada com anticorpo monoclonal específico para proteína $12 \mathrm{kD}$ (Derrick et al, 1992), seguido de incubação com anticorpo anti-camundongo conjugado a fosfatase alcalina. A revelação foi realizada com substratos nitroblue-tetrazolium (NBT) e bromocloro-indolil-fosfato (BCIP).

Devido à ausência de sintomas visuais de declínio, não foi realizado o teste de injeção de água no tronco, visto que alguns autores atribuem melhor desempenho dos resultados quando os sintomas visuais já estão presentes (LEE et al. citado por CARLOS, 1996). 


\subsubsection{Resistência dos porta-enxertos à gomose de Phytophthora}

Para avaliar a resistência dos porta-enxertos à $P$. parasitica, "seedlings" com cerca de $20 \mathrm{~cm}$ de altura foram inoculados com o isolado LRS 95/03 proveniente do Laboratório de Sanidade Animal e Vegetal de Sorocaba Unidade de Pesquisa e Desenvolvimento de Sorocaba da APTA /SAA e selecionado pela maior agressividade dentre 10 isolados pelo Eng. Agr. MSc. Rafael Pio na Esalq-USP.

As folhas foram removidas até a altura aproximada de $15 \mathrm{~cm}$ do colo das plantas e a superfície do caule desinfetada com álcool 70\%. Para a inoculação foi utilizada agulha previamente imergida em álcool $96^{\circ} \mathrm{GL}$ e flambada cuja extremidade foi em seguida passada na borda da colônia, visando à aquisição de micélios do patógeno. A inoculação consistiu na perfuração da haste do "seedling", a $10 \mathrm{~cm}$ de altura do colo, com a agulha infectada. A inoculação com agulha foi utilizada, pois SIVIERO (2001) constatou ser um método eficiente na descriminação dos genótipos jovens com relação à resistência à $P$. parasitica.

A região da inoculação foi protegida com algodão envolvido por esparadrapo cirúrgico de material livre de zinco e umedecido diariamente com água destilada.

O experimento foi conduzido em sala com ambiente climatizado sendo as plantas mantidas sob iluminação artificial constante. O delineamento experimental foi inteiramente casualizado com 13 porta-enxertos e 10 repetições. 


\subsubsection{Determinação das características dos frutos e da poliembrionia das sementes dos citrandarins e dos híbridos de trifoliata}

Em 2003 foi determinado o número total de sementes em 10 frutos de cada porta-enxerto. Em 2004, foram coletados 10 frutos de cada acesso e determinadas as seguintes características: massa, altura, diâmetro, índice de conformação e número de sementes em cada fruto. Também foram determinados: Número médio de embriões por semente (NE): pelo quociente do número de embriões contados pelo número de sementes examinadas; Porcentagem de poliembrionia $(P)$ : obtida através da freqüência das sementes com dois ou mais embriões no total das sementes examinadas.

Para determinar o número médio de embriões por semente, e a porcentagem de poliembrionia e foi utilizado o Método Indireto (MOREIRA et al., 1947).

Após a extração e contagem das sementes dos frutos, em 2004, elas foram lavadas com água, para retirada da mucilagem. Tratadas por imersão em hipoclorito de sódio ( $80 \%$ do produto comercial), com agitação constante por 10 minutos, e, a seguir, com Orthocide 500 (PM). A montagem do experimento foi realizada em câmara de fluxo contínuo, onde, para cada portaenxerto, as sementes foram separadas em três grupos de 10 e colocadas em Placas de Petri, forradas com duas folhas de papel filtro umedecido com água destilada e autoclavada em quantidade 2,5 vezes o peso do papel. As placas foram vedadas com parafilme e colocadas em BOD com temperatura média de $30^{\circ} \mathrm{C}$, estas consideradas adequadas de acordo com os resultados de ROUSE \& SHERROD (1996) e sem controle da umidade relativa. O delineamento experimental foi o de blocos ao acaso, devido a heterogeneidade do ambiente interno à B.O.D provocado pela estratificação das prateleiras. 


\section{RESULTADOS E DISCUSSÃO}

\subsection{Influência dos porta-enxertos na produção de frutos}

Os dados de produção das 13 colheitas controladas são apresentados nos Apêndices 1 à 13. Eles foram submetidos à análise de variância e as médias comparadas pelo teste de Tukey, ao nível de $5 \%$ de probabilidade, levando-se em conta a ocorrência de parcelas perdidas em três tratamentos. Para isso utilizou-se o programa estatístico SAS (Statistical Analysis System).

A perda de plantas decorreu da má formação do sistema radicular de parte das mudas, não relacionada à porta-enxertos, mas sim ao preparo inadequado do solo onde as mudas foram formadas.

As safras foram agrupadas em dois períodos, 1991-1995 e 19962003 com objetivo de avaliarmos o desempenho das plantas nos primeiros oito anos de vida do pomar considerado período de formação e o segundo já fazendo parte da fase adulta do mesmo.

A Tabela 3 mostra as produções, média por planta, de frutos das laranjeiras 'Valência' no período 1991-1995 e o número de plantas sobreviventes. 


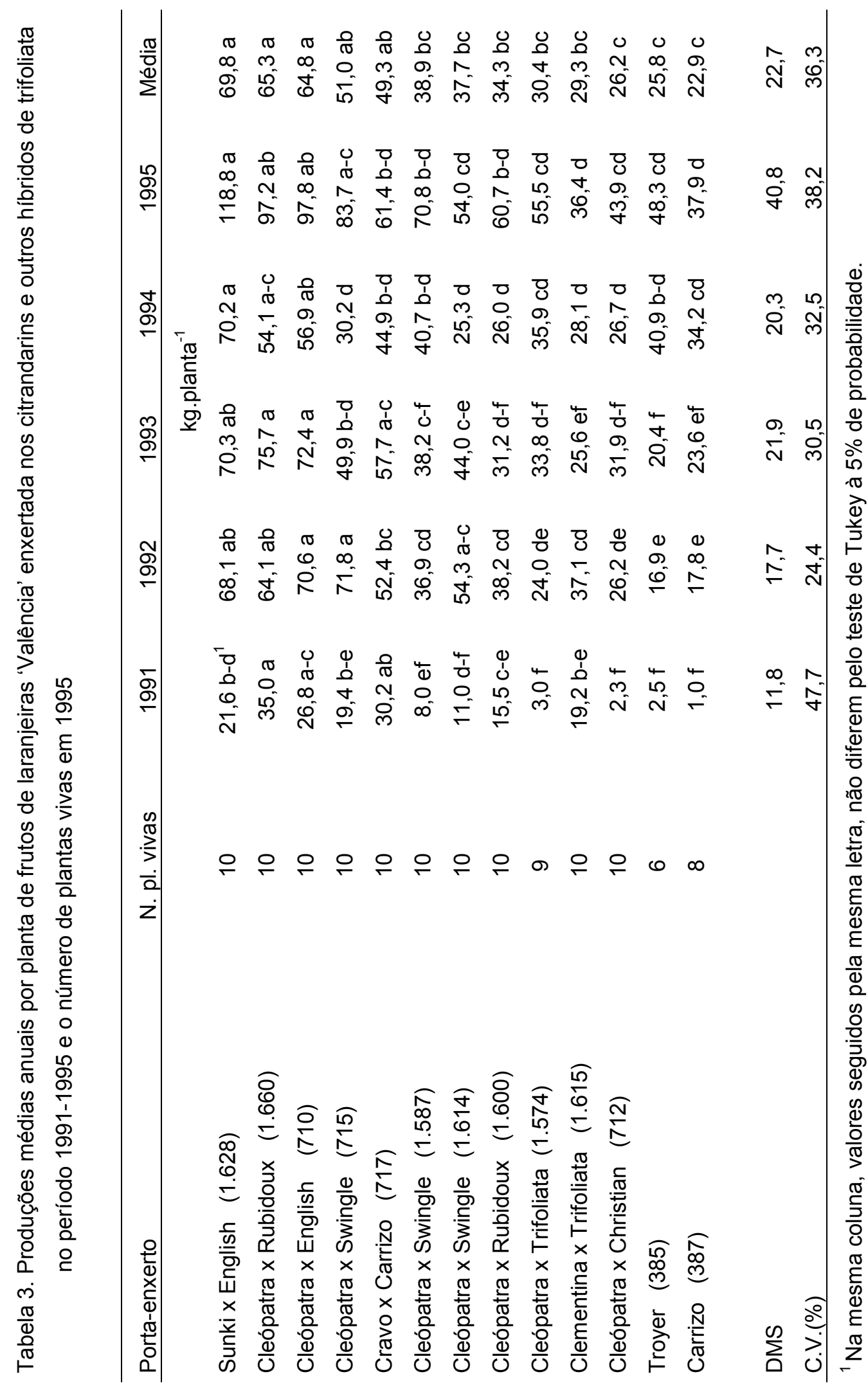


Os cinco porta-enxertos mais produtivos no primeiro qüinqüênio de colheitas, e que não diferiram estatisticamente entre si, em ordem decrescente foram os citrandarins Sunki $x$ English (1.628), Cleópatra $x$ Rubidoux (1.660), Cleópatra $x$ English (710), Cleópatra $x$ Swingle (715) e o trangpur Cravo $x$ Carrizo (717). Dentre eles os mais precoces em iniciarem a produção foram os citrandarins Cleópatra x Rubidoux (1.660) que apresentou a maior produção, $35,0 \mathrm{~kg} \cdot \mathrm{pl}^{-1}$, não diferindo estatisticamente dos porta-enxertos Cravo $\times$ Carrizo (717) e Cleópatra x English (710) com 30,2 e 26,8 kg. $\mathrm{pl}^{-1}$, respectivamente.

O citrandarin Sunki x English (1.628) não revelou precocidade mas a partir da segunda colheita, em 1992, esteve entre os três porta-enxertos mais produtivos, tendo liderado a produção nas colheitas de 1994 e 1995.

O segundo e o terceiro porta-enxertos mais produtivos no período foram os citrandarins Cleópatra x Rubidoux (1.660) e Cleópatra x English (710) sendo que este apresentou maior regularidade na produção tendo ocupado o segundo lugar em todos os anos, exceto em 1991.

O citrandarin Cleópatra $x$ Swingle (715) e o trangpur Cravo $x$ Carrizo (717) que foram o quarto e o quinto porta-enxertos mais produtivos no período, apresentaram irregularidade de produção, sendo que em algumas colheitas foram significativamente inferiores ao porta-enxerto mais produtivo. $\mathrm{O}$ citrandarin Cleópatra x Swingle (715) esteve entre os três porta-enxertos mais produtivos na colheita de 1992 quando ocupou o primeiro lugar, porém ocupou o quinto lugar nas colheitas de 1991 e 1993 e o nono em 1994. Já o trangpur Cravo x Carrizo (717) após um início auspicioso, quando foi o segundo portaenxerto mais precoce, ocupou o quarto e sexto lugares por duas vezes.

Os citranges 'Troyer' (385) e 'Carrizo' (387) que não diferiram estatisticamente entre $\mathrm{si}$, foram os porta-enxertos menos produtivos tendo diferido significativamente dos cinco mais produtivos em quase todas as colheitas e ao final do período. 
O citrandarin Cleópatra x Swingle (715) que foi o quarto portaenxerto mais produtivo no período não diferiu significativamente de seus irmãos-germanos (1.587) e (1.614) embora estes estiveram entre os cinco porta-enxertos mais produtivos em somente uma colheita. Os três têm a característica de apresentarem produções anuais irregulares, quase alternadas.

O citrandarin Cleópatra x Rubidoux (1.660), produziu, nas cinco primeiras colheitas, quase o dobro do peso de frutos obtidos pelo seu homônimo (1.600) sendo estatisticamente diferentes.

A Tabela 4 apresenta as produções médias por planta dos frutos colhidos no período 1996 a 2003 e o número de plantas vivas neste ano.

Os três porta-enxertos mais produtivos em 1991-1995 também o foram neste período. Porém, neste período, o citrandarin Sunki x English (1.628) manteve-se como o mais produtivo em todas as colheitas, exceto em 1997, quando ocupou o segundo lugar, sem diferir estatisticamente do primeiro colocado. No total das treze colheitas, ele apresentou a produção média por planta de $94,8 \mathrm{~kg}$ de frutos, superando estatisticamente os demais portaenxertos, exceto o Cleópatra x English (710).

O segundo e terceiro porta-enxertos mais produtivos foram 0 Cleópatra x English (710) e Cleópatra x Rubidoux (1.660) que não diferiam entre si e mantiveram a performance do período 1991-1995. Entretanto, ambos apresentaram produções anuais irregulares, as vezes significativamente inferiores às obtidas pelo Sunki x English (1.628), posicionando-se, por vezes, entre o quinto e sétimo lugares entre os porta-enxertos mais produtivos. 


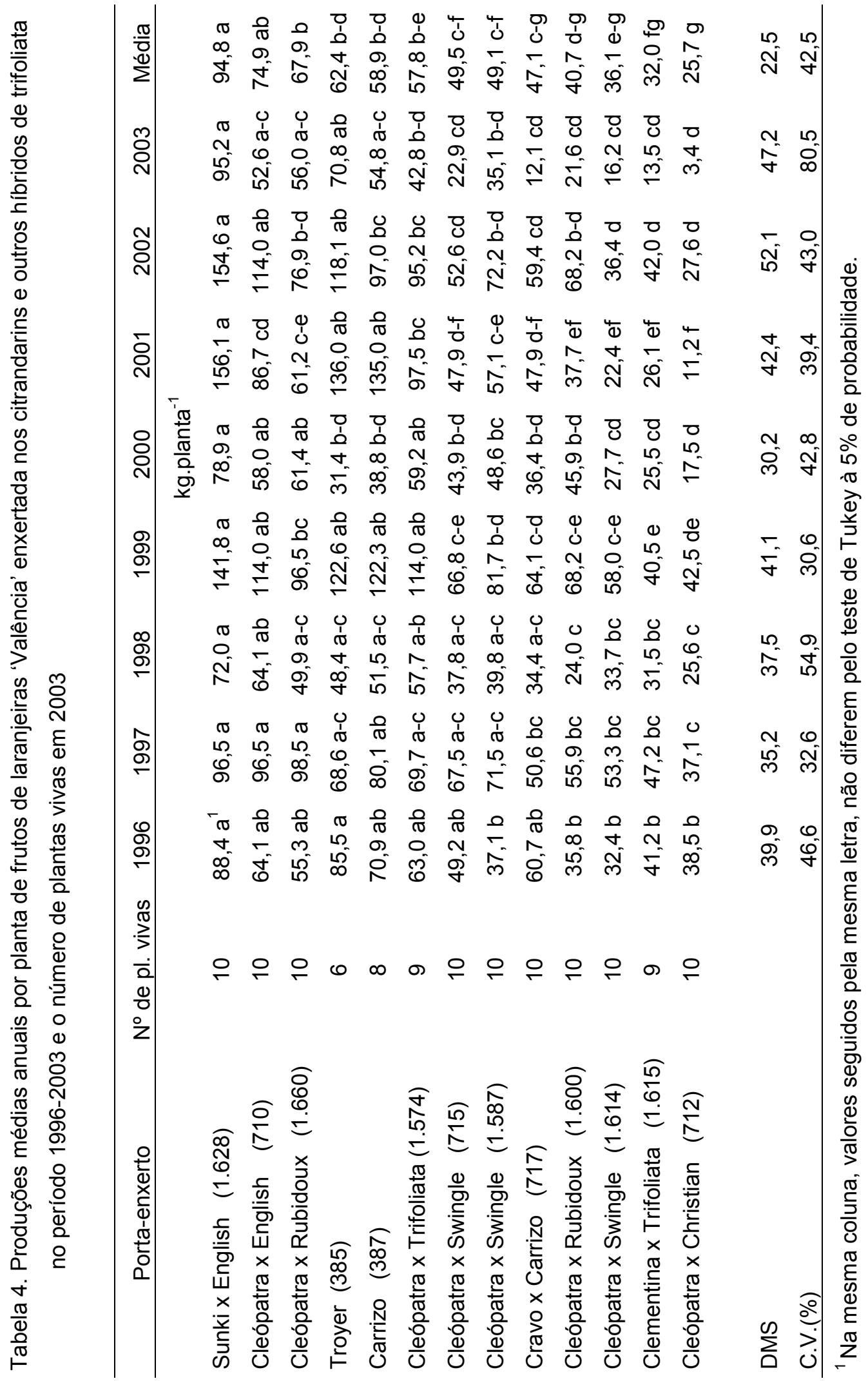


Seguiram-se as eles, os citranges 'Troyer' (385) e 'Carrizo' (387). No período 1991-1995 suas produções anuais foram significativamente inferiores as obtidas com os três melhores porta-enxertos, quais sejam Sunki $x$ English (1.628), Cleópatra x Rubidoux (1.660) e Cleópatra x English (710), tendo terminado o período, como os dois porta-enxertos menos produtivos dentre os treze avaliados. Porém, a partir da colheita de 1996, suas produções não diferiram estatisticamente das obtidas com os três porta-enxertos mais produtivos o que lhes proporcionou a quarta e quinta posições no total das treze colheitas.

O citrange 'Troyer' (385) que apresentou maior irregularidade de produção anual que o citrange 'Carrizo' (387) foi o segundo porta-enxerto mais produtivo nas colheitas de 2001 a 2003.

O citrandarin Cleópatra $x$ Swingle (715) e o trangpur Cravo $x$ Carrizo (717) que, sem diferir do porta-enxerto mais produtivo, tinham ocupado o quinto e sexto lugares entre os porta-enxertos mais produtivos do período 1991-1995, não mantiveram sua performance, posicionando-se em sétimo e nono lugares no conjunto das treze colheitas. A presença de um anel de goma constatado em 2002, na região de união da laranjeira 'Valência' ao trangpur Cravo x Carrizo (717) e considerado como sintoma de incompatibilidade entre essas duas variedades, parece ter prejudicado a performance desse portaenxerto. Em 2003, ele foi o décimo-segundo porta-enxerto.

Apenas o híbrido Cleópatra x Trifoliata (1.574) mostrou melhor desempenho no segundo período quando comparado ao primeiro, tendo passado da nona para a sexta colocação. $\mathrm{Na}$ maioria das colheitas, sua produção não diferiu significativamente daquelas obtidas pelos porta-enxertos mais produtivos.

Os demais porta-enxertos passaram a ocupar posições inferiores as ocupadas no primeiro período, sendo que o citrandarin Cleópatra x Christian (712), sem diferir dos porta-enxertos Cravo x Carrizo (717), Cleópatra $x$ 
Rubidoux (1.600), Cleópatra x Swingle (1.614) e Clementina x Trifoliata (1.615), foi o menos produtivo no total das treze colheitas.

A comparação dos porta-enxertos de mesmos parentais constatou que, os citrandarins Cleópatra x Rubidoux (1.660) e (1.600) diferiram significativamente entre si, tendo o primeiro produzido $40 \%$ mais que o segundo. Porém, os irmãos-germanos, Cleópatra x Swingle (715), (1.587) e (1.614) não diferiram entre si.

\subsection{Altura, diâmetro e volume das copas em 2004}

O diâmetro e altura das plantas estão entre os fatores que determinam o espaçamento mais adequado para uma determinada combinação copa/porta-enxerto.

Os dados da altura, diâmetro e volume médio das copas em março de 2004, quando o experimento tinha 16 anos de idade, são apresentados na Tabela 5. Os dados foram submetidos à análise de variância e as médias comparadas pelo teste de Tukey a $5 \%$ de probabilidade considerando as parcelas perdidas em alguns tratamentos. Para isso utilizou-se o programa estatístico SAS (Statistical Analysis System).

A análise dos dados mostra uma proporcionalidade entre a altura e o diâmetro das copas. Os porta-enxertos que induziram as maiores alturas também proporcionaram os maiores diâmetros e conseqüentemente os maiores volumes às copas das laranjeiras 'Valência'. 
Tabela 5. Altura, diâmetro e volume médio das copas em 2004 de laranjeiras 'Valência' enxertadas em citrandarins e em outros híbridos de trifoliata

\begin{tabular}{lccc}
\hline Porta-enxerto & Altura & Diâmetro & Volume \\
\hline & \multicolumn{2}{c}{$\mathrm{m}$} & $\mathrm{m}^{3}$ \\
Sunki x English (1.628) & $3.6 \mathrm{a}^{1}$ & $3.6 \mathrm{a}$ & $25.2 \mathrm{a}$ \\
Carrizo (387) & $3.5 \mathrm{a}$ & $3.4 \mathrm{ab}$ & $21.9 \mathrm{ab}$ \\
Troyer (385) & $3.3 \mathrm{ab}$ & $3.1 \mathrm{a}-\mathrm{d}$ & $17.2 \mathrm{bc}$ \\
Cleópatra x Trifoliata (1.574) & $2.9 \mathrm{bc}$ & $3.2 \mathrm{a}-\mathrm{c}$ & $16.0 \mathrm{bc}$ \\
Cleópatra x English (710) & $2.8 \mathrm{bc}$ & $3.1 \mathrm{a}-\mathrm{d}$ & $14.4 \mathrm{~cd}$ \\
Cleópatra x Swingle (1.587) & $2.7 \mathrm{~cd}$ & $2.8 \mathrm{c}-\mathrm{f}$ & $11.9 \mathrm{c}-\mathrm{e}$ \\
Cleópatra x Rubidoux (1.660) & $2.6 \mathrm{c}-\mathrm{e}$ & $3.0 \mathrm{~b}-\mathrm{e}$ & $12.7 \mathrm{c}-\mathrm{e}$ \\
Clementina x Trifoliata (1.615) & $2.5 \mathrm{c}-\mathrm{f}$ & $2.5 \mathrm{e}-\mathrm{g}$ & $9.0 \mathrm{~d}-\mathrm{f}$ \\
Cleópatra x Swingle (715) & $2.3 \mathrm{~d}-\mathrm{g}$ & $2.6 \mathrm{~d}-\mathrm{g}$ & $8.5 \mathrm{~d}-\mathrm{f}$ \\
Cleópatra x Rubidoux (1.600) & $2.3 \mathrm{~d}-\mathrm{g}$ & $2.6 \mathrm{~d}-\mathrm{g}$ & $8.5 \mathrm{~d}-\mathrm{f}$ \\
Cleópatra x Swingle (1.614) & $2.2 \mathrm{e}-\mathrm{g}$ & $2.4 \mathrm{fg}$ & $7.3 \mathrm{ef}$ \\
Cravo x Carrizo (717) & $2.1 \mathrm{fg}$ & $2.4 \mathrm{fg}$ & $6.5 \mathrm{ef}$ \\
Cleópatra x Christian (712) & $1.9 \mathrm{~g}$ & $2.1 \mathrm{~g}$ & $4.5 \mathrm{f}$ \\
DMS & 0,43 & 0,53 & 6,30 \\
C.V. (\%) & 10.2 & 11.9 & 32.4 \\
\hline
\end{tabular}

${ }^{1} \mathrm{Na}$ mesma coluna, valores seguidos pela mesma letra, não diferem entre si pelo teste de Tukey a $5 \%$ de probabilidade.

Os porta-enxertos que induziram maior altura às plantas, acima de 3 m, foram Sunki x English (1.628) e os citranges 'Carrizo' (387) e 'Troyer' (385).

Os citrandarins Clementina $x$ Trifoliata (1.615), Cleópatra $x$ Swingle (715) e (1.614), Cleópatra $x$ Rubidoux (1.600) e o trangpur Cravo $x$ Carrizo (717) induziram alturas iguais ou inferiores a $2,5 \mathrm{~m}$, sendo que $\mathrm{o}$ citrandarin Cleópatra x Christian (712) apresentou a menor altura, 1,9 m, o que Ihes conferiu, nestas condições experimentais, "potencial nanicante". Os demais porta-enxertos podem ser considerados como semi-nanicantes, uma vez que proporcionaram plantas com altura inferior a 4 metros. 
O citrandarin Sunki x English (1.628) e os citranges Carrizo (387) e Troyer (385) induziram maior diâmetro às copas, não diferindo estatisticamente de Cleópatra x Trifoliata (1.574), Cleópatra x English (710) todos com diâmetro superior a 3 metros.

Os porta-enxertos que proporcionaram menor diâmetro e, teoricamente, possibilitam maior adensamento de plantio são: Clementina $x$ Trifoliata (1.615), Cleópatra x Swingle (1.614), Cravo x Carrizo (717) e Cleópatra x Christian (712) sendo que este último, induziu altura de 1,9 m e diâmetro de 2,1 metros.

As plantas que apresentaram maior volume de copa foram as enxertadas no citrandarin Sunki x English (1.628) com 25,2 $\mathrm{m}^{3}$, não diferindo do citrange 'Carrizo' (387) 21,9 m³ , e este, não diferindo do 'Troyer' (385) com 17,2 $\mathrm{m}^{3}$. O menor volume, $4,5 \mathrm{~m}^{3}$, foi induzido pelo citrandarin Cleópatra $x$ Christian (712).

Com relação aos porta-enxertos de mesmos parentais, não houve diferença estatística entre eles.

\subsection{Eficiência produtiva das copas}

De modo geral a produção das plantas cítricas é proporcional ao volume da copa porém as plantas menores, via de regra, produzem mais frutos por metro cúbico da copa, ou seja, apresentam maior eficiência produtiva que reflete em menor custo e maior rendimento da colheita.

As eficiências produtivas das combinações avaliadas neste experimento foram calculadas anualmente para 1999, 2000 e 2003, dividindo-se as produções médias por planta pelos volumes médios das copas, mensurados 
três meses após a colheita. As dimensões das plantas em 2000, 2001 e 2004 são apresentadas nos Apêndices 14 à 22, e os valores utilizados no cálculo das eficiências produtivas na Tabela 6 . Os dados de eficiência produtiva foram submetidos a análise de variância e para comparação das médias foi utilizado o teste de Tukey a $5 \%$ de probabilidade utilizando o programa ESTAT.

Com poucas e aleatórias exceções foi reconfirmado que aos maiores volumes de copa corresponderam as maiores produções e que plantas menores apresentaram eficiência produtiva semelhante ou até superior as de maior porte, como pode ser visto na Tabela 6 , onde as copas sobre os portaenxertos Cleópatra x Swingle (1.614) e Cleópatra x Rubidoux (1.600) eram, em média, $70 \%$ menores que as sobre Sunki $x$ English (1.628) e apresentaram eficiência produtiva semelhantes.

A análise de variância mostrou que os dados foram significativos com relação aos anos, porém não foi constatada diferença significativa entre as médias utilizando o teste de Tukey a $5 \%$ de probabilidade.

Os citrandarins que apresentaram maior eficiência produtiva, superior à 6,0 kg.m ${ }^{-3}$, foram Cleópatra x Rubidoux (1.600) e (1.660), Cleópatra x Trifoliata (1.574) e Cleópatra x English (710). Os citranges 'Troyer' (385) e 'Carrizo' (387) apresentaram comportamento muito semelhante com 5,4 e 4,8 $\mathrm{kg} \cdot \mathrm{m}^{-3}$. Apesar de não diferirem estatisticamente dos citrandarins Cleópatra $\mathrm{x}$ Rubidoux (1.660) e (1.660) os citranges apresentaram uma redução de $20 \%$ com relação à produção de frutos por metro cúbico de copa. O citrandarin Clementina $x$ Trifoliata (1.615) foi o porta-enxerto que apresentou a mais baixa eficiência produtiva $3,4 \mathrm{~kg} \cdot \mathrm{m}^{-3}$, com redução ao redor de $50 \%$ quando comparado aos citrandarins Cleópatra x Rubidoux (1.600) e (1.660).

Os híbridos de mesmos parentais apresentaram entre si, eficiências produtivas muito semelhantes. 

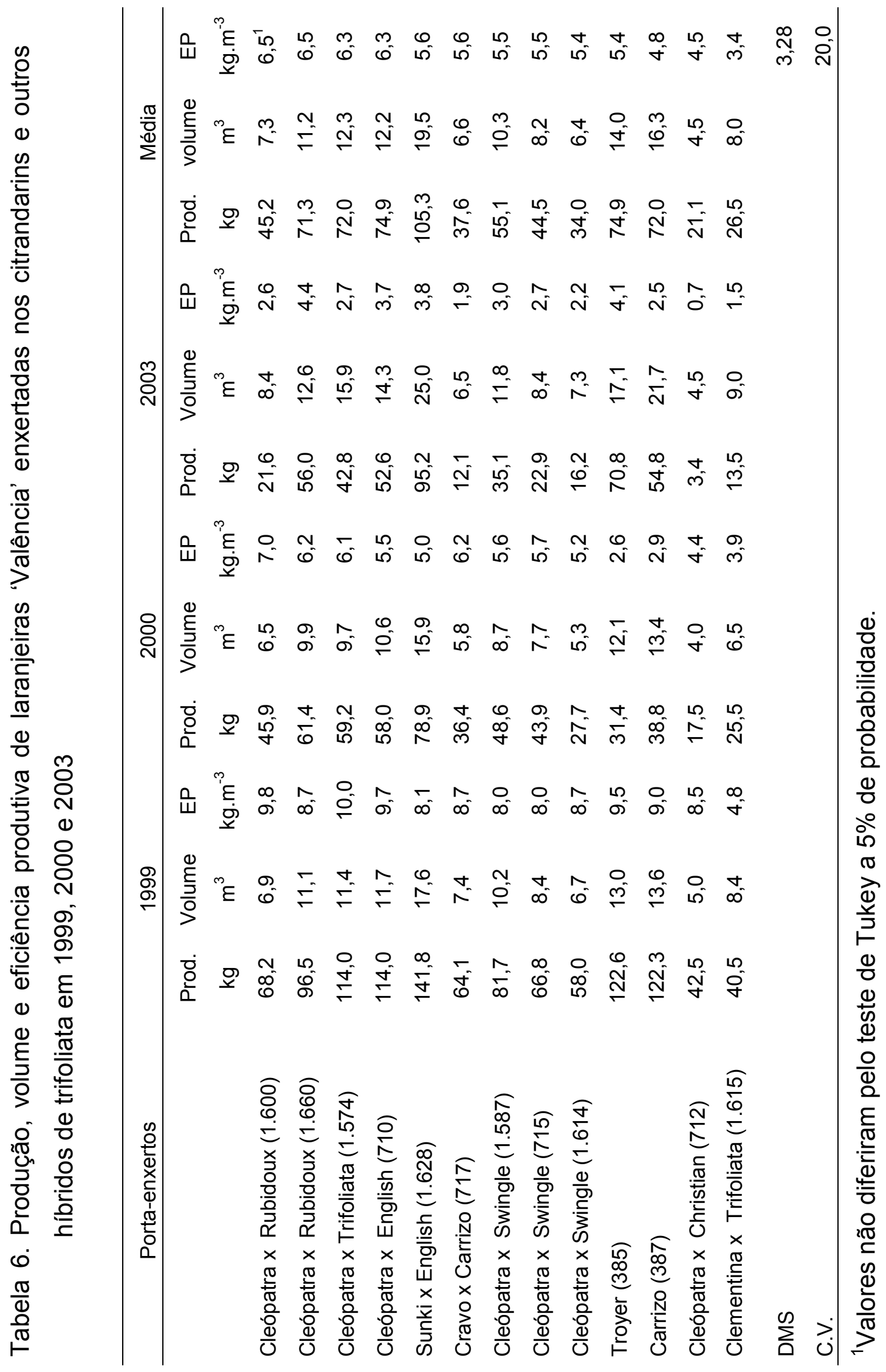


\subsubsection{Considerações teóricas sobre produção, tamanho das plantas e espaçamento}

Tendo em vista que o espaçamento utilizado no experimento foi 7,5 m x 4,2 m e que, em 2004, apenas uma planta, em todo o experimento, apresentou, diâmetro de copa igual a 4,2 m, é razoável supor que as plantas puderam crescer livremente e que as dimensões alcançadas aos 16 anos de idade são reais.

Com base nesse raciocínio, calculou-se o número teórico de plantas por hectare para cada combinação copa/porta-enxerto por meio da fórmula $A=0,85 D \times(D+2,5)$ onde $A$ é a área teórica adequada para cada combinação e $\mathrm{D}$ o diâmetro médio das copas.

A fórmula foi elaborada admitindo que haja a superposição de 15 $\%$ dos ramos nas linhas de plantio e que a distância livre entre as linhas seja de 2,5 m, considerada suficiente para a realização dos tratos culturais (DE NEGRI \& BLASCO, 1991).

Esses pomares hipotéticos foram comparados quanto às produções obtidas nas 5 e nas 13 colheitas.

Os dados, apresentados na Tabela 7, teorizam que um hectare de laranjeiras 'Valência' enxertadas no citrandarin Cleópatra x English (710) e plantadas no espaçamento de 2,6m x 5,6 m (536 pl.ha $\left.^{-1}\right)$ teria produzido $223 \mathrm{t}$ de frutos, ocupando a quarta posição nas cinco primeiras colheitas e a primeira colocação, com $669 \mathrm{t}$, nas 13 colheitas .

Os laranjais formados sobre Sunki x English (1.628) com 529

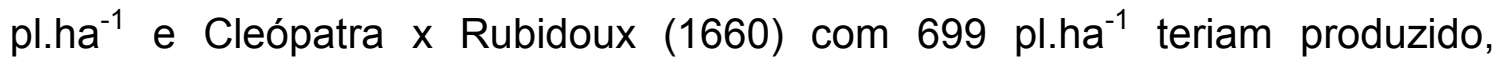
respectivamente, 185 e 229 t.ha $^{-1}$ em cinco colheitas e 652 e 617 t.ha $^{-1}$ em 13 colheitas. Eles ocuparam respectivamente a sexta e a segunda colocação dentre os mais produtivos nas primeiras cinco colheitas. $O$ trangpur Cravo $x$ 


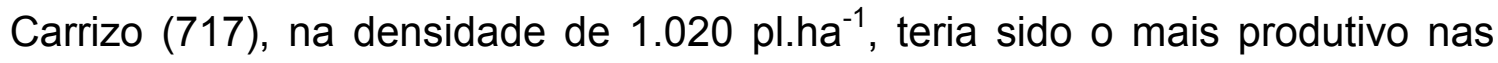
cinco colheitas, com $252 \mathrm{t}$ de frutos, mas ocuparia o terceiro lugar no total das 13 colheitas, com $612 \mathrm{t}$ de frutos.

As laranjeiras 'Valência' enxertadas em citrange 'Troyer' eram, em 2004, menores que as enxertadas no citrange 'Carrizo', o que permitiria a densidade de 687 pl.ha $^{-1}$ contra 584 pl.ha $^{-1}$ sobre o Carrizo. Elas teriam produzido $89 \mathrm{t}$ de frutos nas cinco colheitas, o que as posicionaria na décimasegunda posição, e 557 t no total das 13 colheitas, quando então ocupariam o sexto lugar dentre os pomares mais produtivos. Já o citrange 'Carrizo' (387), teria induzido a produção de $67 \mathrm{t}$ de frutos nas cinco colheitas e de $448 \mathrm{t}$ nas 13 colheitas, o que lhe teria proporcionado a décima-terceira e a décima-primeira colocação respectivamente.

As menores plantas do experimento eram as enxertadas no citrandarin Cleópatra x Christian (712) com 2,1 m de diâmetro médio de copa. Um hectare conteria 1.208 laranjeiras 'Valência' que produziriam $158 \mathrm{t}$ de frutos nas primeiras cinco colheitas o que posicionaria esse porta-enxerto em sétimo lugar. Porém sua performance produtiva cairia para o décimo-segundo lugar no total das 13 colheitas em decorrência de terem produzido somente $403 \mathrm{t}$ de frutos.

Considerando as produções das cinco e treze colheitas, o número de mudas a serem adquiridas e os tratos culturais requeridos por planta podese teorizar que os porta-enxertos Sunki x English (1.628), Cleópatra x English (710) e Cleópatra $x$ Rubidoux (1.660) seriam os mais adequados para a instalação de um pomar de laranjeiras 'Valência'. 


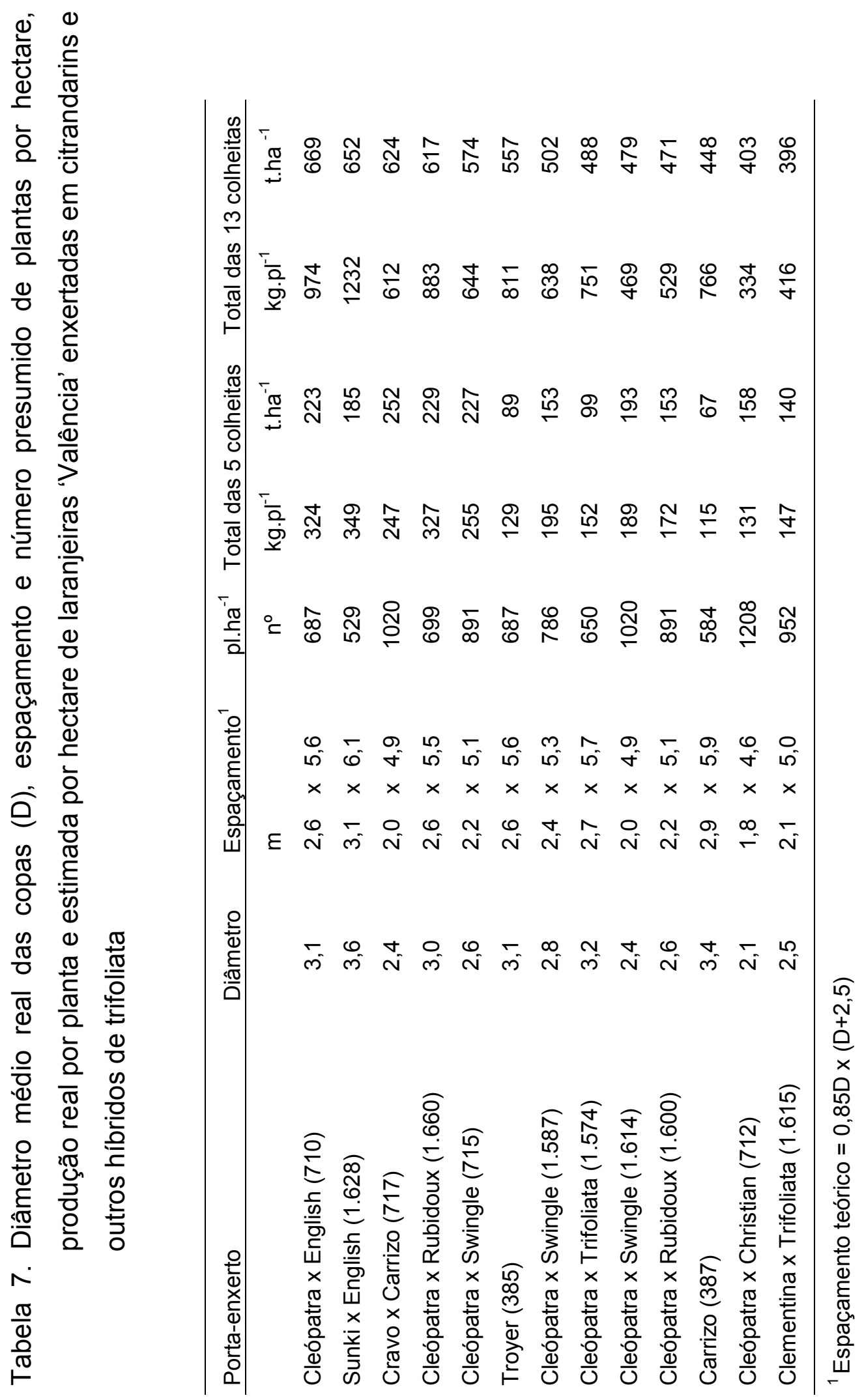




\subsection{Qualidade dos frutos}

Em outubro de 2001, 2002 e 2003 foram coletadas amostras de dez frutos de três blocos e determinadas as características de maior interesse comercial. Em 2003 não foram coletados frutos do tratamento Cleópatra $x$ Christian (712) pelas não representatividade das amostras.

Nos Apêndices 23, 24 e 25, são apresentados os dados computados e na Tabela 8 os valores médios obtidos. A análise estatística foi efetuada considerando uma parcela perdida utilizando o programa ESTAT.

A análise de variância mostrou haver diferenças significativas, pelo Teste $F$, com relação aos anos, com exceção para altura e diâmetro do fruto e porcentagem de suco. A comparação entre as médias, realizada através do Teste de Tukey à $5 \%$ não mostrou diferenças significativas para os valores de massa, altura, diâmetro e índice de conformação do fruto e acidez do suco.

De modo geral os porta-enxertos foram semelhantes quanto à porcentagem de suco, que variou entre 45 e $52 \%$, com exceção para o Cleópatra x English (710) que diferiu estatisticamente de Cleópatra x Trifoliata (1.574) e do híbrido Clementina x Trifoliata (1.615).

Foram constatadas diferenças significativas nos teores de sólidos solúveis totais, os quais variaram de 13,8 a $11,0{ }^{\circ}$ Brix. Os maiores teores foram induzidos pelos porta-enxertos Cleópatra $x$ Christian (712), Clementina $x$ Trifoliata (1.615), Cleópatra x Swingle (715), não diferindo estatisticamente de Cleópatra x Rubidoux (1.660) e Cleópatra x Swingle (1.587). De modo geral, os porta-enxertos que induziram os maiores teores de sólidos solúveis apresentaram os menores valores de massa do fruto. 


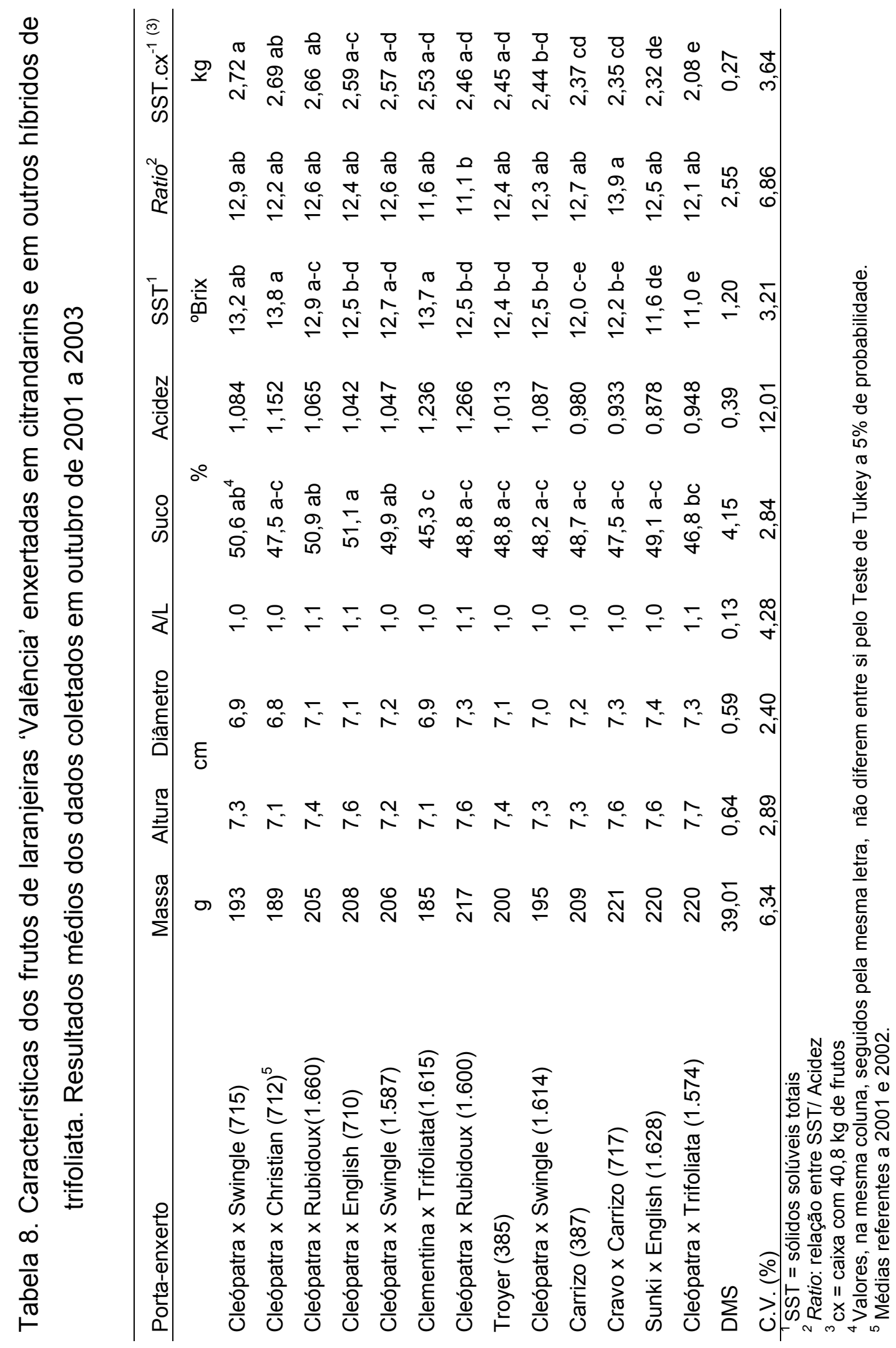


Como, de modo geral, aos maiores valores de acidez corresponderam os mais altos teores de sólidos solúveis e vice-versa, os dados de ratio foram semelhantes entre $\mathrm{si}$, tendo sido constatado diferenças significativas somente entre o trangpur Cravo x Carrizo (717) e o híbrido de Cleópatra x Rubidoux (1.600) com 13,9 e 11,1 respectivamente.

Os citrandarins Cleópatra x Swingle (715), Cleópatra x Christian (712) e Cleópatra x Rubidoux (1.660) induziram as maiores quantidades de sólidos solúveis por caixa (40,8 $\mathrm{kg}$ de frutos), com valores próximos a 2,7 kg. Sem diferirem entre $\mathrm{si}$, eles foram significativamente superiores ao citrange 'Carrizo' (387), ao trangpur Cravo x Carrizo (717) e Sunki x English (1.628) os quais produziram $2,3 \mathrm{~kg}$ de sólidos solúveis por caixa. $\mathrm{O}$ mais baixo teor foi induzido pelo citrandarin Cleópatra x Trifoliata (1.574) com 2,0 kg.

A comparação visual da cor do suco com os padrões utilizados nas indústrias de suco não mostrou diferenças entre os porta-enxertos.

\subsection{Produção de frutos e sólidos solúveis por planta}

De modo geral, os frutos cítricos são comercializados para consumo "in natura" ou para processamento industrial atendendo as conveniências do produtor. Assim, é desejável a seleção de porta-enxertos que induzam às plantas grandes produções de frutos e também de sólidos solúveis. 


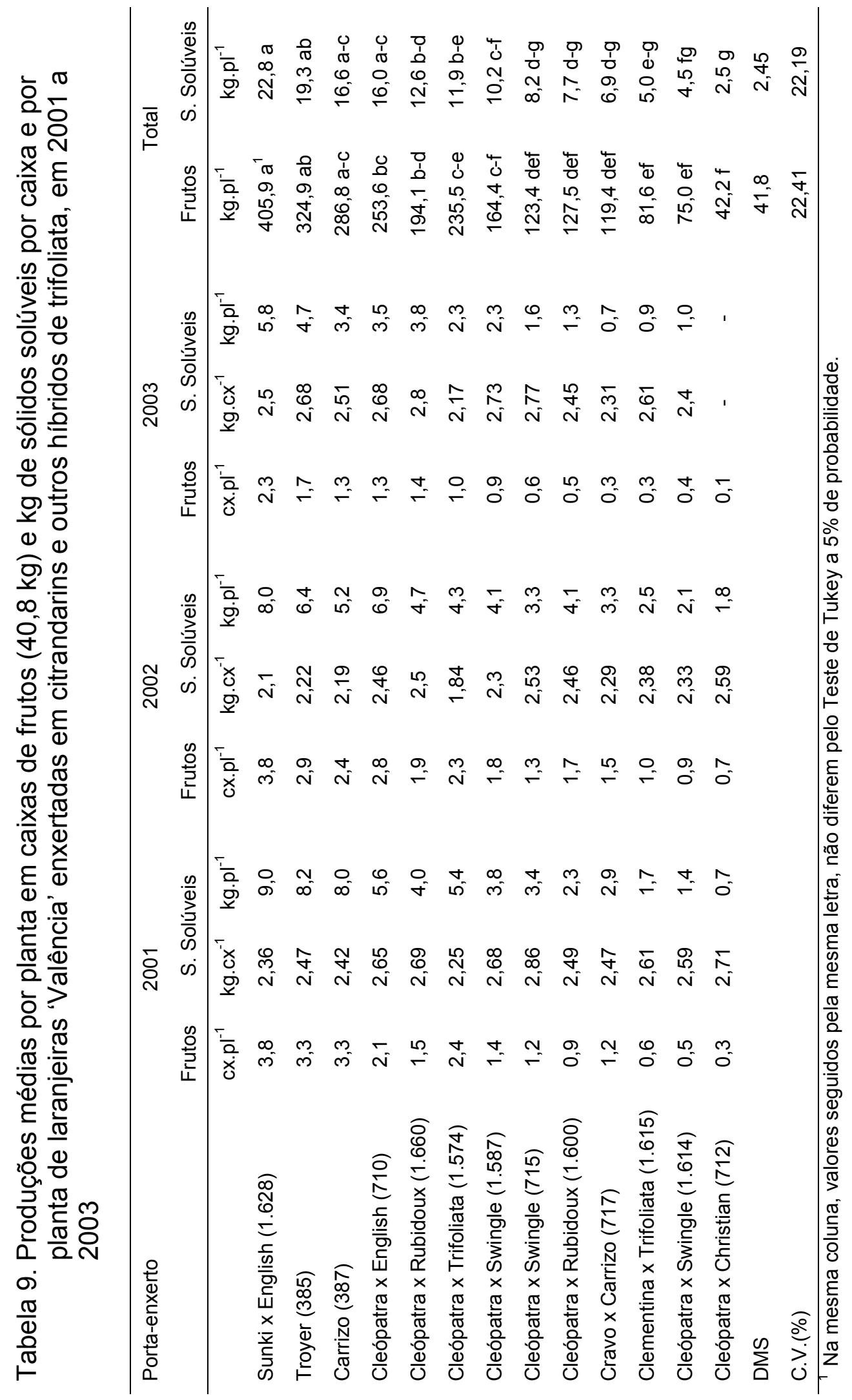


A análise de variância mostrou haver diferenças significativas, pelo Teste $F$, entre os anos e os porta-enxertos.

Os dados da Tabela 9 revelam que, nos três anos avaliados, o citrandarin Sunki x English (1.628) induziu as maiores produções de frutos e de sólidos solúveis por planta.

Seguiram-se a ele os citranges 'Troyer' (385) e 'Carrizo' (387), e o citrandarin Cleópatra x English (710), nessa ordem, sendo que os dois primeiros, não diferiram significativamente do citrandarin Sunki $x$ English (1.628) na produção de frutos e de sólidos solúveis produzidos no triênio, enquanto que o Cleópatra x English (710) somente diferiu na produção de frutos.

O citrandarin Cleópatra $x$ Rubidoux (1.660) apesar de ter produzido, em média, $66 \mathrm{~kg}$ de frutos e $5 \mathrm{~kg}$ de sólidos solúveis por planta a mais que seu homônimo (1.600) dele não diferiu estatisticamente.

Os citrandarins Cleópatra x Swingle (1.587), (715) e (1.614) não diferiram entre si, porém os dois primeiros produziram quase o dobro, de frutos e de sólidos solúveis, que o terceiro.

Foi observado que os porta-enxertos mais produtivos proporcionaram menor quantidade de sólidos solúveis por caixa de frutos na média do triênio.

\subsection{Resistência dos porta-enxertos a Phytophthora parasitica}

A coleta dos dados do comprimento e largura da lesão sob a casca e do diâmetro do porta-enxerto foi realizada 55 dias após a inoculação (Apêndice 26), sendo que no decorrer do experimento a temperatura média foi de $26,3^{\circ} \mathrm{C}$ e a umidade relativa do ar $82 \%$. 
Como os porta-enxertos apresentavam diâmetros diferentes decidiu-se compará-los pela porcentagem de área lesionada ou seja pela relação entre as áreas da lesão e do porta-enxerto, expressa em porcentagem.

A área da lesão foi calculada pela fórmula da área da elipse $(A=$ 0,785 x comprimento $\times$ largura) e a área do porta-enxerto, na região da inoculação, utilizando a fórmula da área do retângulo tendo como altura o valor constante de $1 \mathrm{~cm}$ (comprimento da maior lesão constatada em todos os portaenxertos) e como largura o diâmetro do porta-enxerto na região de inoculação.

A porcentagem da área lesionada ao nosso ver é mais representativa, que somente o comprimento ou a largura ou ainda a área da lesão tendo em vista os diferentes diâmetros dos porta-enxertos.

Os dados foram submetidos à análise de variância e foi utilizado o teste de Tukey, à $5 \%$ de probabilidade, para comparação das médias. Os dados foram calculados utilizando arco seno, porém, na Tabela 10, são apresentados os dados reais.

O citrandarin Cleópatra $\mathrm{x}$ English (710) apresentou a maior porcentagem de área lesionada (47,4\%) por $P$. parasitica não diferindo dos citrandarins Cleópatra x Swingle (715), Sunki x English (1.628) e Cleópatra $x$ Christian (712).

Os citranges 'Troyer' (385) e 'Carrizo' (387) apresentaram comportamento semelhante com relação a porcentagem de área lesionada, média de $30 \%$.

Apesar dos citranges não terem diferido significativamente dos híbridos Clementina x Trifoliata (1.615), Cravo x Carrizo (717), Cleópatra $x$ Rubidoux (1.600), Cleópatra x Trifoliata (1.574) e Cleópatra x Swingle (1.587), eles apresentaram menor resistência ao patógeno, proporcionando lesões $11 \%$ maiores. 
Tabela 10. Porcentagem da área do porta-enxerto lesionada por inoculação com $P$. parasitica, utilizando o método da agulha infectada, decorridos 55 dias da inoculação

\begin{tabular}{|c|c|}
\hline Porta-enxerto & Área lesionada \\
\hline & $\%$ \\
\hline Cleópatra x English (710) & $47,4 a^{1}$ \\
\hline Cleópatra x Swingle (715) & $37,2 a b$ \\
\hline Sunki x English (1.628) & $36,8 a b$ \\
\hline Cleópatra x Christian (712) & $36,1 \mathrm{ab}$ \\
\hline Cleópatra x Swingle (1.614) & $30,3 \mathrm{bc}$ \\
\hline Carrizo (387) & $30,0 \mathrm{~b}-\mathrm{d}$ \\
\hline Troyer (385) & 27,2 b-d \\
\hline Cleópatra x Rubidoux (1.660) & $27,3 b-d$ \\
\hline Clementina x Trifoliata (1.615) & $19,7 \mathrm{~cd}$ \\
\hline Cravo x Carrizo (717) & $18,1 \mathrm{~cd}$ \\
\hline Cleópatra x Rubidoux (1.600) & $18,1 \mathrm{~cd}$ \\
\hline Cleópatra x Trifoliata (1.574) & $16,7 \mathrm{~cd}$ \\
\hline Cleópatra x Swingle (1.587) & $15,7 d$ \\
\hline DMS & 9,9 \\
\hline C.V. & 20,6 \\
\hline
\end{tabular}

${ }^{1}$ Valores, seguidos pela mesma letra não diferem pelo Teste de Tukey a $5 \%$ de probabilidade. 
Os dados revelaram que descendentes de mesmos parentais apresentaram comportamento diferenciado a $P$. parasítica, o que pode ser visto pela comparação dos híbridos Cleópatra x Swingle (715), (1.614) e (1.587) onde este foi significativamente menos danificado que seus irmãos. $O$ mesmo não foi constatado nos descendentes de Cleópatra $x$ Rubidoux e entre os citranges 'Troyer' e 'Carrizo' ambos descendentes de laranja Washington navel (C. sinensis (L.) Osb.) x $P$. trifoliata e indistinguíveis por marcadores moleculares (COLLETA et al., 2004).

Possivelmente, a elevada heterozigose existente nos citros pode ser o fator responsável pelos valores discrepantes apresentados por descendentes de mesmos parentais, com relação à resistência a $P$. parasítica. BROADBENT \& GOLLNOW (1994), citando Hutchison, relataram que a resistência à gomose de Phytophthora é controlada por diversos genes o que explica a diversidade de resistência de híbridos de mesmo parentais. Esses autores verificaram que citrandarins de mesmo parentais (Scarlet $x$ Trifoliata) apresentavam valores antagônicos de resistência à gomose de P.citrophthora.

BOAVA et al. (2003) utilizando o mesmo método de inoculação deste trabalho, não constataram diferenças significativas entre híbridos de trifoliata de mesmo parentais quanto a resistência à gomose de $P$. parasítica. As divergências entre os resultados podem estar na forma de avaliação dos danos causados pelo patógeno, uma vez que utilizaram a altura da lesão e não a porcentagem da área lesionada, bem como na virulência da estirpe que foi a LRS 23/97 e também no estado nutricional das plântulas.

CARVALHO (2000) relata que híbridos de tangerina Sunki e $P$. trifoliata e seus recíprocos foram os mais promissores para resistência a $P$. parasítica o que não foi confirmado no presente trabalho, onde o citrandarin Sunki $x$ English esteve entre os porta-enxertos com maior porcentagem de área lesionada. 


\subsection{Tolerância dos porta-enxertos à tristeza dos citros}

Até março de 2004 não foram vistos sintomas que possam ser atribuídos a intolerância dos porta-enxertos ao vírus da tristeza.

POMPEU JUNIOR et al. (2002a, b) relataram que os citrandarins 'Changsha x English Small', 'Changsha x English Large' e 'Sunki x Benecke' e dois citromônias Cravo $\mathrm{x}$ Swingle eram tolerantes à tristeza após acompanharem por 13 anos o comportamento de laranjeiras 'Valência' enxertadas nesses híbridos.

WUTSCHER \& BOWMAN (1999) também não constataram intolerância ao vírus da tristeza dos citrandarins 'Sunki x Benecke', Sunki $x$ Flying Dragon e do citromônia Rangpur $x$ Swingle, após avaliação em campo por oito anos também com copa de laranja 'Valência'.

Embora esses resultados fossem esperados, uma vez que os parentais são tolerantes ou imunes ao vírus da tristeza, poderiam ocorrer híbridos sensíveis. Assim, FORNER \& FORNER-GUINER (2002) relataram que cruzamentos entre citrange 'Troyer' e as tangerinas 'Cleópatra' e comum, e das tangerinas 'Cleópatra' e 'King' e do citrange 'Troyer' com P. trifoliata originaram híbridos tolerantes ou suscetíveis à tristeza. Por outro lado, apareceram híbridos tolerantes à tristeza em uma população em que a laranja 'Azeda' e o limão Verna (C. limon Burm.) eram os parentais.

Os porta-enxertos não foram avaliados quanto à tolerância ao complexo Capão Bonito porque ele não foi constatado na região. 


\subsection{Resistência dos porta-enxertos ao declínio dos citros}

O exame visual, em março de 2004, não revelou a ocorrência dos sintomas típicos do declínio em nenhuma das plantas.

Os resultados dos testes realizados em 22/03/2004, foram negativos, para as 65 amostras, com relação à presença da proteína $12 \mathrm{kD}$ precursora dos sintomas de declínio nas plantas. Foi verificado apenas um positivo-fraco para a amostra do bloco II do citrandarin Cleópatra x Trifoliata (1574). O teste foi repetido, em 23/03/2004, com material da mesma amostragem e seus resultados confirmaram o anterior.

Assim, os porta-enxertos podem ser considerados não suscetíveis ao declínio dos citros até os 16 anos de idade.

Entretanto é razoável supor que o declínio possa se manifestar com o envelhecimento das plantas, como relatado por CASTLE (1993), tendo em vista que os trifoliatas e citranges são, de modo geral, suscetíveis ao declínio (BERETTA et al., 1986, 1994).

POMPEU JUNIOR et al. (2002) constataram que apenas uma laranjeira 'Valência' enxertada nos citrandarins 'Changsha x English Small' e 'Sunki x Benecke', com 13 anos de idade, manifestaram sintomas de declínio estando próximas a um talhão de laranjeiras 'Pêra' sobre limão 'Cravo', com idade semelhante, com mais de $60 \%$ de plantas sintomáticas.

Coincidentemente WUTSCHER \& BOWMAN, (1999) verificaram sintomas de declínio em apenas uma laranjeira 'Valência' com oito anos de idade, enxertada nos citrandarins 'Sunki x Benecke' e King x Rubidoux. 


\subsection{Características dos porta-enxertos}

Na Tabela 11 são apresentados os dados coletados de frutos dos citrandarins e outros híbridos de trifoliata participantes deste trabalho e ilustrados nas Figuras 1 e 2.

Tabela 11. Valores médios de massa, altura, diâmetro, índice conformação do fruto e número de sementes de 10 frutos, coletados em 2004 e número médio de sementes em 2003

\begin{tabular}{|c|c|c|c|c|c|c|c|}
\hline \multirow[t]{2}{*}{ Porta-enxerto } & \multicolumn{4}{|c|}{ Características do fruto } & \multicolumn{3}{|c|}{$\begin{array}{c}\mathrm{N} . \mathrm{de} \\
\text { sementes/fruto }\end{array}$} \\
\hline & Massa & Altura & Diâmetro & $A / L$ & 2004 & 2003 & Média \\
\hline & g & & $\mathrm{cm}$ & & & $\mathrm{n}$. & \\
\hline Troyer (385) & 101 & 5,9 & 5,7 & 1,0 & 17,2 & 18,0 & 18 \\
\hline Cleópatra x Swingle (1.587) & 91 & 5,3 & 6,0 & 0,9 & 19,6 & 21,7 & 21 \\
\hline Carrizo (387) & 88 & 5,7 & 5,7 & 1,0 & 19,6 & 13,0 & 16 \\
\hline Cleópatra x Rubidoux (1.660) & 72 & 4,9 & 5,4 & 0,9 & 25,7 & 29,0 & 27 \\
\hline Cleópatra x Swingle (1.614) & 65 & 4,7 & 5,1 & 0,9 & 14,1 & 19,5 & 17 \\
\hline Cleópatra x Christian (712) & 60 & 4,5 & 5,0 & 0,9 & 13,3 & 15,0 & 14 \\
\hline Cleópatra x Trifoliata (1.574) & 57 & 4,4 & 5,0 & 0,9 & 12,0 & 8,0 & 10 \\
\hline Cleópatra x English (710) & 56 & 4,5 & 5,1 & 0,9 & 22,8 & 24,7 & 24 \\
\hline Cleópatra x Swingle (715) & 56 & 4,7 & 5,2 & 0,9 & 19,7 & 23,2 & 21 \\
\hline Cleópatra x Rubidoux (1.600) & 54 & 4,3 & 4,9 & 0,9 & 10,8 & 18,3 & 15 \\
\hline Cravo x Carrizo (717) & 52 & 4,4 & 4,7 & 0,9 & 10,7 & 14,0 & 12 \\
\hline Clementina $\times$ Trifoliata (1.615) & 50 & 4,5 & 4,7 & 0,9 & 2,3 & 2,0 & 2 \\
\hline Sunki x English (1.628) & 42 & 3,9 & 4,4 & 0,9 & 14,0 & 20,0 & 17 \\
\hline
\end{tabular}



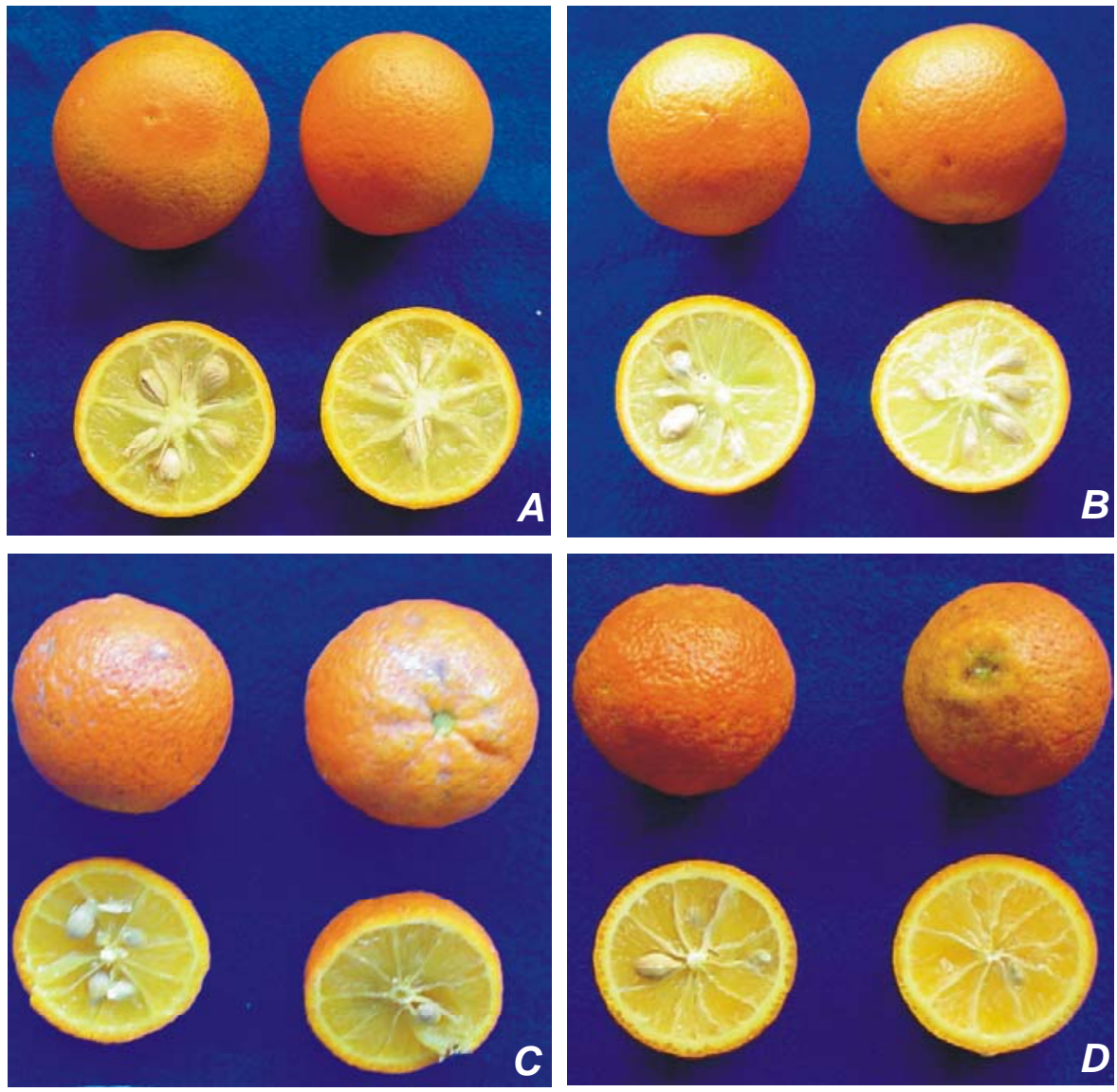

Figura 1 - Citranges $(A)$ Troyer e $(B)$ Carrizo; $(C)$ Trangpur Cravo x Carrizo (717); (D) Clementina x Trifoliata (1.615) 

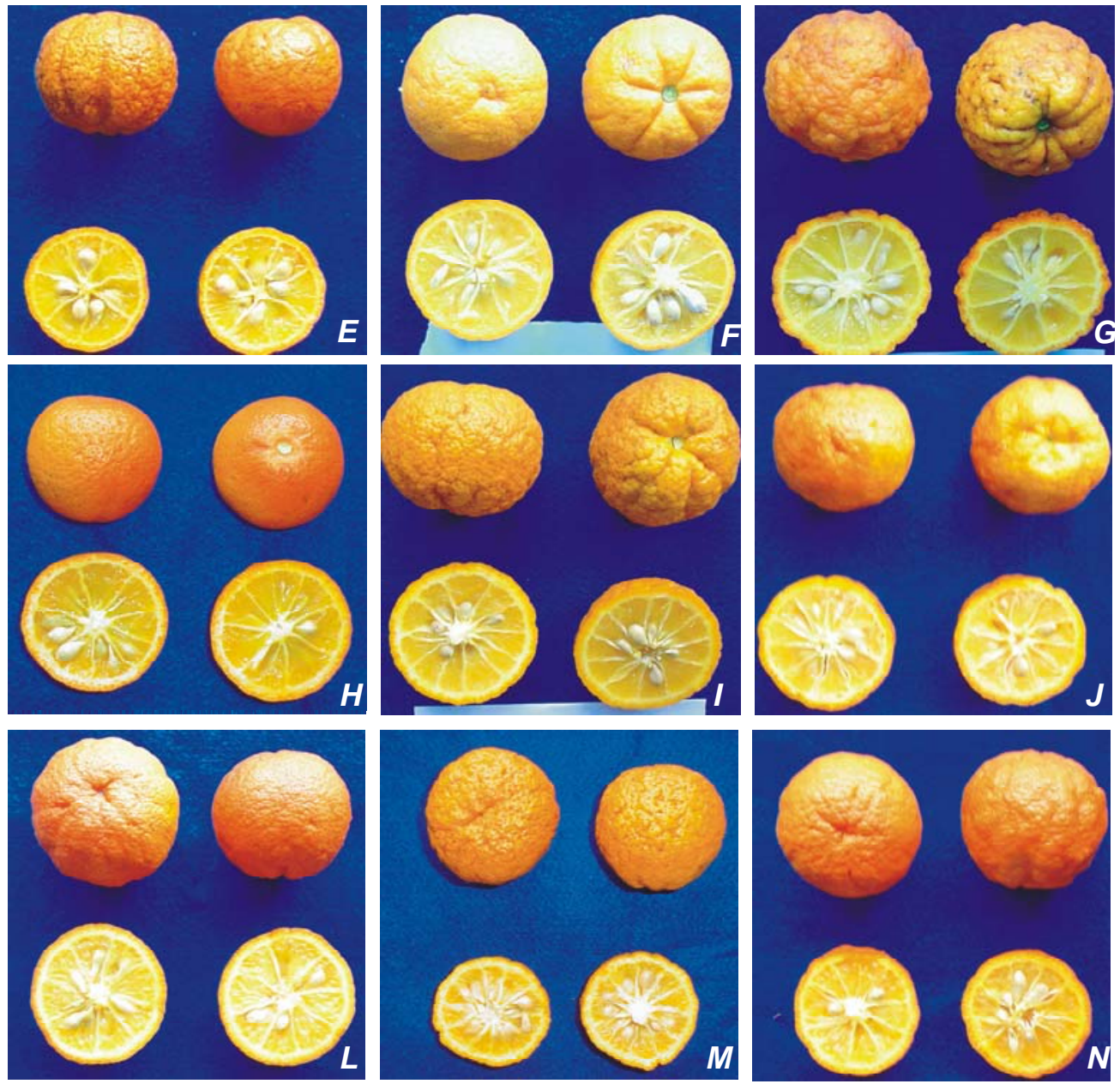

Figura 2 - Citrandarins: $(E)$ Sunki $x$ English (1.628); ( $F$ e G) Cleópatra x Rubidoux (1.660) e (1.600); (H, I e J) Cleópatra x Swingle (1614), (1.587) e (715); $(L)$ Cleópatra x Trifoliata (1.574); $(M)$ Cleópatra x English (710) e $(N)$ Cleópatra x Christian (712) 
Os dados e as figuras mostram que os frutos são pequenos, com massa inferior a 100 gramas, ligeiramente achatados, com casca aderente, variando de lisa a rugosa, com pouca ou nenhuma pubescência, cor amarela à alaranjada. O pouco caldo tem sabor acre e coloração amarela à esverdeada.

Apresentam grande número de sementes por fruto. $O$ maior foi verificado no citrandarin Cleópatra x Rubidoux (1.660) com 27 sementes por fruto e o menor, 10 sementes, no híbrido Cleópatra $x$ Trifoliata (1.574), com exceção da Clementina x Trifoliata (1.615) que apresentou, nos dois anos, duas sementes por fruto sendo $40 \%$ apirenos. As sementes dos citrandarins e do trangpur são, em média, menores que as dos citranges 'Troyer' (385) e 'Carrizo' (387).

A coleta das sementes é feita de abril a junho.

\subsubsection{Determinação do número médio de embriões e da poliembrionia das sementes dos porta-enxertos}

A propagação seminífera dos porta-enxertos pressupõe a ocorrência de embriões nucelares. Segundo GURGEL, (1952), nas sementes cítricas ocorre a formação de um embrião zigótico sendo os demais quase sempre nucelares.

Com o objetivo de determinar o número médio de embriões e a porcentagem de sementes poliembriônicas, 30 sementes de cada portaenxerto, foram separadas em grupos de 10 e colocadas em Placas de Petri, forradas com papel de filtro umidecido, vedadas com parafilme e colocadas em B.O.D. com temperatura média de $30^{\circ} \mathrm{C}$.

A ocorrência de fungos saprofíticos nas Placas de Petri que continham as sementes de Clementina x Trifoliata (1.615), associado à 
dificuldade de obter sementes, provocaram a exclusão desse acesso do experimento.

Os citranges 'Troyer' (385) e 'Carrizo' (387) também foram excluídos devido à insuficiência de germinação das sementes nas condições experimentais.

Aos 56 dias decorridos da instalação do experimento, foi realizada a contagem do número de embriões germinados em cada semente pela contagem das plântulas que apresentavam a emissão da radícula e da parte aérea (Figura 3).

O número médio de embriões por semente (NE) foi obtido dividindo-se o número total de embriões contados pelo número de sementes consideradas, e a percentagem de poliembrionia $(P)$ expressa pela relação entre o número de semente com dois ou mais embriões e o número de sementes consideradas (Apêndice 27)

Os valores obtidos são apresentados na Tabela 12 com seus números originais. Para a realização da análise de variância os dados de número médio de embriões (NE) foram transformados em $\sqrt{x+1}$ e os referentes à porcentagem de poliembrionia $(P)$ em arc sen $x+1$, e para comparação dos tratamentos, procedeu-se o Teste de Tukey a $5 \%$ de probabilidade utilizando o programa ESTAT.

A análise de variância não revelou diferença significativa para os blocos. No teste de comparação de médias, utilizando Tukey a $5 \%$ de probabilidade, não foram constatadas diferenças significativas entre os portaenxertos com relação ao número médio de embriões por semente, os quais variaram de 1,9 à 1,2 , sendo que os híbridos de mesmos parentais apresentaram valores semelhantes. Com relação à porcentagem de poliembrionia, o citrandarin Cleópatra $x$ English (710) e o trangpur Cravo $x$ Carrizo (717) diferiram estatisticamente apenas da Cleópatra x Christian (712). 
A porcentagem de sementes poliembrionicas variou de 17 a $70 \%$, sendo que os híbridos de mesmo parentais apresentaram valores semelhantes. Pela classificação proposta por MOREIRA et al. (1947) apenas os citrandarins Cleópatra x Rubidoux (1.600) e Cleópatra x Christian (712) apresentaram média poliembrionia, sendo os demais altamente poliembriônicos.

Assim como verificado por MOREIRA et al. (1947), foi observado a presença de embrião contendo três cotilédones em uma semente do trangpur Cravo x Carrizo (717) e do citrandarin Cleópatra x Swingle (1.587).

Tabela 12. Número médio de embriões por semente (NE), porcentagem $(P)$ e classificação da poliembrionia dos citrandarins e outros híbridos de trifoliata

\begin{tabular}{lccc}
\hline Porta-enxerto & NE & $\mathrm{P}$ & Classificação $^{(1)}$ \\
\hline Cleópatra x English (710) & $\mathrm{n}$. & $\%$ & \\
Cravo x Carrizo (717) & 1,9 & $70 \mathrm{a}^{2}$ & ALTA \\
Cleópatra x Swingle (1.587) & 1,8 & $67 \mathrm{a}$ & ALTA \\
Sunki x English (1.628) & 1,6 & $53 \mathrm{ab}$ & ALTA \\
Cleópatra x Swingle (715) & 1,9 & $50 \mathrm{ab}$ & ALTA \\
Cleópatra x Swingle (1.614) & 1,6 & $43 \mathrm{ab}$ & ALTA \\
Cleópatra x Trifoliata (1.574) & 1,4 & $34 \mathrm{ab}$ & ALTA \\
Cleópatra x Rubidoux (1.660) & 1,3 & $30 \mathrm{ab}$ & ALTA \\
Cleópatra x Rubidoux (1.600) & 1,2 & $30 \mathrm{ab}$ & ALTA \\
Cleópatra x Christian (712) & 1,3 & $27 \mathrm{ab}$ & MÉDIA \\
C.V. & 1,2 & $17 \mathrm{~b}$ & MÉDIA \\
\hline
\end{tabular}

${ }^{1}$ Classificação da poliembrionia, por contagem indireta, segundo Moreira et al. (1947).

${ }^{2}$ Valores, seguidos pela mesma letra, não diferem pelo Teste de Tukey a $5 \%$ de probabilidade. 


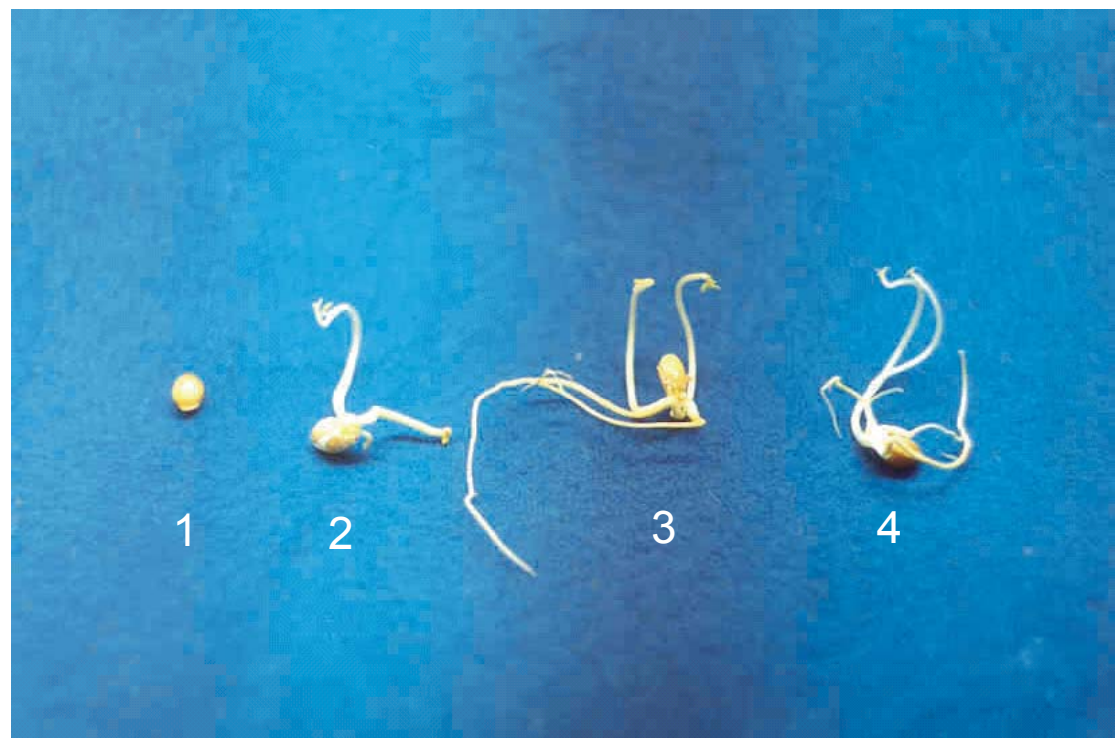

Figura 3 - Avaliação do número médio de embriões e porcentagem de poliembrionia das sementes dos porta-enxertos pelo método indireto (Moreira et al., 1947) baseado na emissão da radícula e da plúmula.(1) Ausência de germinação; (2) (3) e (4) Um ou mais embriões germinados por semente

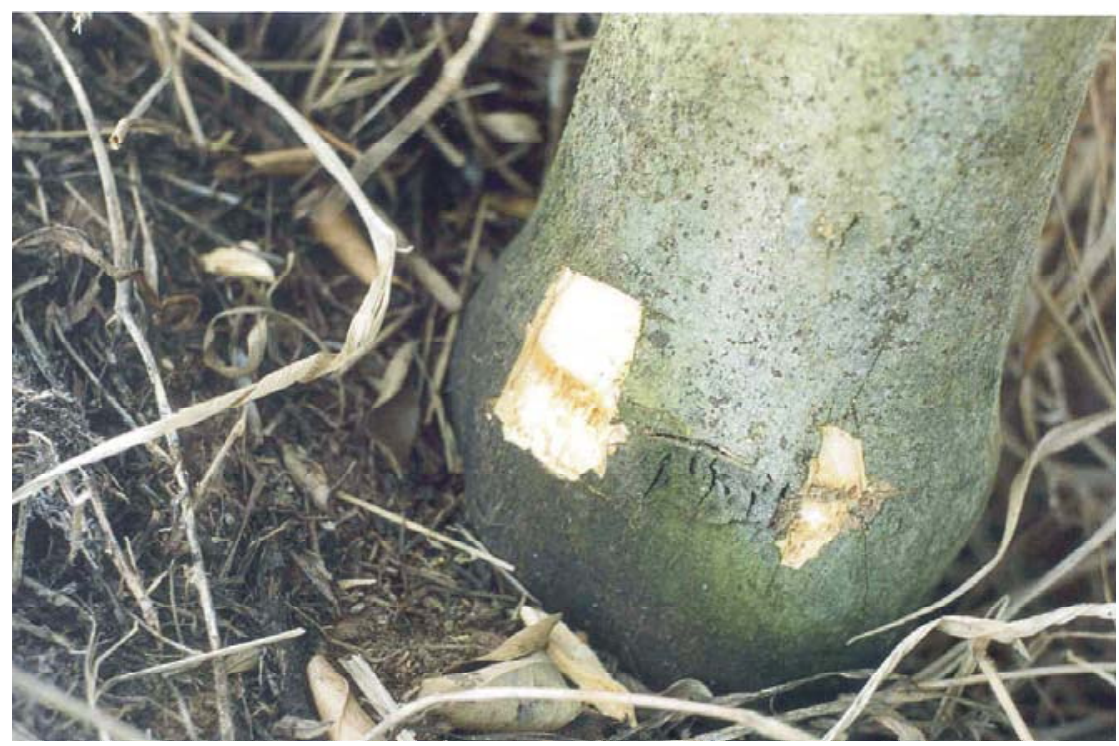

Figura 4 - Região da enxertia de laranjeira Valência enxertada no trangpur Cravo x Carrizo (717) mostrando sintomas de incompatibilidade. 


\subsection{Ocorrência de incompatibilidade entre a laranjeira 'Valência' e trangpur Cravo x Carrizo (717)}

Uma das razões da escolha da laranja 'Valência' para copa do experimento, foi a ausência de relatos de sua incompatibilidade com outros porta-enxertos exceto o limão 'Rugoso' (BRIDGES \& YOUTSEY, 1968).

Em decorrência do definhamento de algumas plantas enxertadas no Cravo x Carrizo (717) e da presença de uma linha de depressão na região da enxertia, procedeu-se, em junho de 2002, a retirada da casca de três plantas. Em duas foram encontradas pontuações necróticas e depressão do lenho semelhantes às relatadas por NAURIYAL et al. (1958); BISIO et al. (1989); POMPEU JUNIOR et al. (1972) e consideradas indicadoras de incompatibilidade entre copa e porta-enxerto (Figura 4).

Em agosto de 2004 foi verificado que as plantas dessa combinação se mostraram depauperadas e que $80 \%$ delas mostravam sinais de incompatibilidade na região da enxertia.

Sabe-se que o trangpur Cravo x Carrizo, é incompatível com copas de laranja 'Pêra' e tangor 'Murcott' (POMPEU JUNIOR \& BLUMER, 2002 b), porém não foram encontrados relatos recentes da ocorrência dessa anomalia envolvendo a laranja 'Valência' e híbridos de trifoliata. Essa constatação, que representa mais um percalço na seleção de novos portaenxertos foi relatada por POMPEU JUNIOR \& BLUMER (2002 a). Ela ressalta a necessidade de estudos visando a sua detecção precoce que poderiam vir a resultar em economia de tempo e de recursos, no já longo processo de seleção de porta-enxertos. 


\section{CONCLUSÕES}

O citrandarin Sunki x English (1.628) não revelou precocidade de produção de frutos mas, a partir da segunda colheita, esteve entre os três portaenxertos mais produtivos tendo liderado a produção em nove das treze colheitas controladas.

Os citrandarins Sunki x English (1.628), Cleópatra x Rubidoux (1.660) e Cleópatra $x$ English (710), sem diferir estatisticamente entre si, foram os porta-enxertos mais produtivos no primeiro qüinqüênio e também no total das treze colheitas.

Os citranges 'Troyer' (385) e 'Carrizo' (387) que não diferiram entre si em todas as colheitas, foram os menos produtivos nas cinco primeiras colheitas. A partir da sexta, suas produções não diferiram das proporcionadas pelos três porta-enxertos mais produtivos.

O citrandarin Sunki x English (1.628) e os citranges 'Troyer' (385) e 'Carrizo' (387) induziram as maiores alturas e diâmetros, ao redor de 3,5m, e o citrandarin Cleópatra x Christian (712) as menores, cerca de 2 metros.

Os citrandarins Clementina $x$ Trifoliata (1.615), Cleópatra $x$ Swingle (715) e (1.614), Cleópatra x Rubidoux (1.600) e Cleópatra x Christian (712) mostraram potencial nanicante possibilitando obter laranjeiras 'Valência' com alturas iguais ou inferiores a 2,5 metros. 
As maiores copas proporcionaram as maiores produções porém, não foram constatadas diferenças significativas nas eficiências produtivas que situaram-se entre 6,5 e 3,4 quilogramas de frutos por metro cúbico de copa.

O citrandarin Sunki x English (1.628) e os citranges 'Troyer' (385) e 'Carrizo' (387), sem diferirem entre si, lideraram a produção de frutos e de sólidos solúveis por planta no triênio 2001-2003.

Foram constatadas diferenças significativas nas porcentagens de área lesionada por P. parasitica. Os citrandarins Cleópatra x Swingle (1.587), Cleópatra $x$ Trifoliata (1.574) e Cleópatra $x$ Rubidoux (1.600) foram os mais resistentes e Cleópatra $x$ English (710), Cleópatra $x$ Swingle (715) e Sunki $x$ English (1.628) os mais suscetíveis.

Os porta-enxertos não manifestaram sintomas de intolerância a tristeza e ao declínio.

Os frutos dos porta-enxertos apresentaram número médio de sementes entre 27, encontrado no citrandarin Cleópatra x Rubidoux (1.660) e 10, observado no Cleópatra $x$ Trifoliata (1.574). Foi exceção o Clementina $x$ Trifoliata (1.615) com média de duas sementes por fruto, dos quais $40 \%$ apirenos.

Os porta-enxertos apresentaram média a alta porcentagem de sementes poliembriônicas, com número médio de embriões entre 1,9 e 1,2.

Foi constatada a ocorrência de incompatibilidade entre a laranjeira 'Valência' e o trangpur Cravo x Carrizo (717). 


\section{REFERÊNCIAS BIBLIOGRÁFICAS}

AGUILAR-VILDOSO, C.I.; POMPEU JUNIOR, J. Inoculação de Phytophthora parasítica em caule de variedades cítricas pelo método do palito. Fitopatologia Brasileira, v.22 p. 240, Supl., 1997.

ALENCAR, J. Podridão do pé dos citros. Viçosa: Escola Superior de Agricultura de Minas Gerais, 1941. 4p. (Boletim, 6).

BASSANEZI, R.B.; BERMAGIM-FILHO, A.; AMORIM, L. et al. Spatial and temporal analyses of citrus sudden death, as a tool to generated hypotheses concerning its etiology. Phytopathology, v.93, p.502-512, 2003.

BASSANEZI, R.B.; GIMENES-FERNANDES, N.; MASSARI, C.A. Resultados do levantamento detalhado da morte súbita dos citros na região afetada junho a setembro de 2002. Araraquara: Fundecitrus, 2002. 9p.

BERETTA, M.J.G. POMPEU JUNIOR, J.; TEÓFILO SOBRINHO, J. et al. Avaliação do declínio de plantas cítricas em clones de limões 'Cravo' e 'Volkameriano'. In: CONGRESSO. BRASILEIRO DE FRUTICULTURA, 8., Brasília, 1986. Anais. Brasilia: Sociedade Brasileira de Fruticultura, 1986a. p. 243-247.

BERETTA, M.J.G.; ROSSETTI, V.; TEÓFILO SOBRINHO, J. et al. Incidência do declínio de plantas cítricas em diversos porta-enxertos. In: CONGRESSO BRASILEIRO DE FRUTICULTURA, 8., Brasília, 1986. Anais. Brasília: Sociedade Brasileira de Fruticultura, 1986b. p.237- 241. 
BERETTA, M.J.G.; POMPEU JUNIOR, J.; TEÓFILO SOBRINHO, J. et al. Incidência do declínio de plantas cítricas em diferentes clones de trifoliata. In: CONGRESSO BRASILEIRO DE FRUTICULTURA, 9., Campinas, 1987. Anais. Campinas: Sociedade Brasileira de Fruticultura, 1988. p.395-399.

BERETTA, M.J.G.; POMPEU JUNIOR, J.; DERRICK, K.S. et al. Evaluation of roostocks in Brasil for field resistence to declinio. In: INTERNATIONAL CITRUS CONGRESS, Acireale, 1992. Proceedings. Acireale: International Society of Citriculture, 1994. p.841-843.

BITANCOURT, A.A. A doença dos citros no Vale do Paraíba. O Biológico, n.6, p.268-269, 1940.

BITTERS, W.P.; MCCARTY, C.D.; COLE, D.A. An evaluation of trifoliate orange selections as rootstocks for Washington navel and Valencia orange. In: WORLD CONGRESS OF CITRICULTURE, 1., Valencia, 1973. Proceedings. Murcia: International Society of Citriculture, 1973. p.127-131.

BLUMER, S.; SALVA, R.; POMPEU JUNIOR, J. Evolução do uso dos portaenxertos nos viveiros de mudas cítricas de São Paulo. (compact disc). In: CONGRESSO BRASILEIRO DE FRUTICULTURA, 18., Florianópolis, 2004. Anais. Florianópolis: Sociedade Brasileira de Fruticultura, 2004.

BOAVA, L.P.; SIVIERO, A.; MASUDA, Y. et al. Resistência de citrandarins e citranges a Phytophthora parasitica. Laranja, v.24, n.1, p.135-144, 2003.

BORDIGNON, R.; MEDINA FILHO, H.P.; SIQUEIRA, W.J.; PIO, R.M. Características da laranjeira 'Valência' sobre clones e híbridos de portaenxertos tolerantes à tristeza. Bragantia, v.62, n.3, p.381-395, 2003. 
BOWMAN, K.D. New hybrid citrus rootstocks developed by U. S. Department of Agriculture. In: INTERNATIONAL CITRUS CONGRESS, Orlando, 2000. Proceedings. Orlando: International Society of Citriculture, 2003. p.51.

BRIDGES, G.D.; YOUTSEY, C.O. Further studies of the bud-union abnormality of rough lemon rootstocks with sweet orange scions. In: CONFERENCE OF THE INTERNATIONAL ORGANIZATION OF CITRUS VIROLOGISTS, 4., Catania, 1966. Proceedings. Gainesville: International Organization of Citrus Virologists, 1968. p.236-239.

BROADBENT, P.; GOLLNOW, B.I. Selecting disease-tolerant citrus rootstocks for Australia. In: INTERNATIONAL CITRUS CONGRESS, Acireale, 1992. Proceedings. Acireale: International Society of Citriculture, 1994. p. 758-764.

CAMERON, J. W., FROST, H.B. Genetics, breeding and nucellar embriony. In: REUTHER, W.; BATCHELOR, L. D.; WEBBER, H.J. Citrus Industry. Riverside: University of Califórnia, 1968. p. 325-370.

CARLOS, E.F. Avaliação de proteínas associadas ao declínio dos citros em plantas interenxertadas. Jaboticabal, 1996. 71p. Dissertação (Mestrado) - Faculdade de Ciências Agrárias e Veterinárias, Universidade Estadual Paulista "Júlio de Mesquita Filho".

CARVALHO, M.L.T. Reação de porta-enxertos híbridos de citros à infecção de tronco e raízes por Phytophthora parasítica. Campinas, 2000. 87 p. Tese (Doutorado) - Instituto de Biologia, Universidade Estadual de Campinas.

CASTLE, W.S. Performance of citrus scions and rootstocks under trial in Florida. In: INTERNATIONAL CONGRESS OF CITRUS NURSERYMEN, 4., Nelspruit, 1993. Proceedings. Nelspruit: South African Citrus Nurserymen's Association, 1993. p. 319-327. 
CASTLE, W.S.; YOUTSEY, C.O.; HUTCHISON, D.J. Rangpur lime x Troyer citrange, a hybrid citrus rootstock for closely spaced trees. Proceedings. Gainesville: Florida State Horticultural Society, v.99, 1986. p.33-35.

CASTLE, W.S.; TUCKER, D.P.H; KREZDORN, A.H.; YOUTSEY, C.O. Rootstocks for Florida Citrus. Gainesville: Institute of food and agricultural sciences, University of Florida Press, 1993. 92p.

CHAPOT, H. The citrus plant. In: HAFLIGER, E. (Ed.). Citrus. Basileia: Ciba-Geigy Agrochemicals, 1975. p. 6-13.

CHIACCHIO, F.P.B.; GALLI, F. Influência da copa e do vigor das plantas cítricas sobre o comportamento do porta-enxerto em relação a Phytophthora parasítica Dastur e Phytophthora citrophthora (SM \& SM) Leonian. Revista Brasileira de Fruticultura. v.1, n.3, p.35-45,1978.

COLLETA FILHO, H.D.; POMPEU JUNIOR, J.; MACHADO, M.A. Certificação genética de porta-enxertos de citros: dados de 2003. Laranja, v.25, n.1, p. 171178, 2004.

COSTA, A.S.; GRANT, T.J.; MOREIRA, S. Behavior of various citrus rootstockscion combinations following inoculation with mild and severe strains of tristeza virus. Proceedings. Gainesville: Florida State Horticultural Society, v.67, p.2630, 1954.

CRISTOFANI, M. Mapas de ligação de Citrus sunki hort ex Tan. e Poncirus trifoliata (L.) cv. Rubidoux e localização do gene de resistência ao vírus da tristeza. Piracicaba, 1997. 140p. Tese (Doutorado).- Escola Superior de Agricultura "Luiz de Queiroz", Universidade de São Paulo. 
DE NEGRI, J.D.; BLASCO, E.E.A. Planejamento e implantação de um pomar cítrico. In: RODRIGUEZ, O.; VIĖGAS, F.; POMPEU JUNIOR, J.; AMARO, A.A. (Ed.). Citricultura brasileira. Campinas: Fundação Cargill, 1991. v.1, p.318332.

DERRICK, K.S.; LEE, R.F.; BRLANSKY, R.H. et al. Proteins associated with citrus blight. Plant Disease, v.74, n.2, p. 168-170, 1990.

DERRICK, K.S.; BARTHE, G.A.; HEWITT, B.G. et al. Detection of citrus blight by serological assays. Proceedings. Gainesville: Florida State Horticultural Society, v.105, p.26-28, 1992.

DI GIORGI, F.; IDE, B.Y.; DIB, K. et al. Contribuição ao estudo do comportamento de algumas variedades de citros e suas implicações agroindustriais. Laranja, v.11, n.2, p. 567-612, 1990.

DONADIO, L.C.; STUCHI, E.S.; SEMPIONATO, O. R. New hybrids as rootstock for Pera sweet orange. In: INTERNATIONAL CONGRESS OF CITRUS NURSEYMEN, 6., Ribeirão Preto, 2001. Proceedings. Bebedouro: Estação Experimental de Citricultura de Bebedouro, 2001. p. 137-139.

FEICHTENBERGER, E. Doenças incitadas por Phytophthora em citros. In: LUZ, E.D.M.N; MATSUOKA, K.; SANTOS, A.F. (Ed.). Doenças causadas por Phytophthora no Brasil. Campinas: Livraria Rural, 2001. p. 283-342.

FEICHTENBERGER, E.; MUNTANER, A.I.C.; ROSSETTI, V.; LEITE, Y. et al. Estudo comparativo da resistência a Phytophthora spp. de quinze seleções de Poncirus trifoliata (L.) Raf. com copa de laranjeira Hamlin de clone nucelar. In: Congresso Brasileiro de Fruticultura, 4, Salvador, 1977. Anais Salvador: Sociedade Brasileira de Fruticultura, 1978. p. 131-136. 
FEICHTENBERGER, E.; ROSSETTI, V.; POMPEU JUNIOR, J.; TEOFILO SOBRINHO, J. Evaluation of tolerance to Phytophthora species in scion rootstock combinations of citrus in Brazil: a review. In: INTERNATIONAL CITRUS CONGRESS, Acireale, 1992. Proceedings. Acireale: International Society of Citriculture, 1994. p.854-858.

FEUCHT, W. Graft incompatibility of tree crops: a overview of the present cientific status. Acta Horticulturae, n.227, p.33-41, 1988

FEUCHT, W.; SCHMID, P.P.S. Incompatibility of grafted cherry trees ( $P$. avium/P. cerasus): loss of metabolic tolerance as a consequence of environmental stress. Acta Horticulturae. In: INTERNATIONAL SYMPOSIUM ON VEGETATIVE PROPAGATION OF WOODY SPECIES: www.acthort.org/books/227/227 9.htm. (set. 2002).

FORNER, J.B.; FORNER-GINER, M. A. Programa de melhoramento de portaenxertos na Espanha. In: SEMINÁRIO INTERNACIONAL DE CITROS: MELHORAMENTO, 7., Bebedouro, 2002. Anais. Bebedouro: Estação Experimental de Citricultura de Bebedouro, 2002. p.82-95.

FORNER,J.B. FORNER, M. A.; ALCAIDE, A.; VERDEJO-LUCAS, S,; SORRIBAS, F.J. New hybrid citrus rootstocks released in Spain. In: INTERNATIONAL CITRUS CONGRESS, Orlando, 2000. Proceedings. Orlando: International Society of Citriculture, 2003. p.58-61.

GIMENES-FERNANDES, N.; BASSANEZI, R.B. Doença de causa desconhecida afeta pomares cítricos no norte de São Paulo e sul do Triângulo Mineiro. Summa Phytopathologica, v.27, p. 93, 2001.

GRAHAM, J.H.; BRIGHT, D.B.; MCCOY, C.W. Phytophthora - Diaprepes weevil complex: Phytophthora spp. relationship with citrus rootstocks. Plant Disease, v.87, n.1, p. 85-90, jan. 2003. 
GRANT, T.J.; MOREIRA, S.; SALIBE, A.A. Citrus variety reaction to tristeza virus in Brazil when used in various rootstock and scion combinations. Plant Disease Reporter, v.45, p.416-421. 1961.

GRIMM, G.R.; HUTCHISON, D.J. Evaluation of Citrus spp. relatives and hybrids for resistence to Phytophthora parasitica Dastur. In: INTERNATIONAL CITRUS CONGRESS, Orlando, 1977. Proceedings. Gainesville: International Society of Citriculture, 1977. p. 863-865.

GROSSER, J. W.; CHANDLER, J.L. Hibridação somática no melhoramento de porta-enxertos para citros. In: SEMINÁRIO INTERNACIONAL DE CITROS: MELHORAMENTO, 7. Bebedouro, 2002. Anais. Bebedouro: Estação Experimental de Citricultura de Bebedouro, 2002. p.141-147.

GURGEL, J.T.A. Poliembrionia e embriogenia adventícia em Citrus, Mangifera e Eugênia. Dusenia, v.1, n.6, p. 443-450, 1952.

HARTMANN, H. T.; KESTER, D. E. Theorical aspects of graftíng and budding. In: Plant Propagation: principles and practices. 2. ed., London: Prentíce-Hall Intemational, 1968. 702p.

KIRKPATRICK, J., D.; BITTERS, W P.; FOOTE, F. J. Incompatibility of Price and Cook nucellar Eureka lemon trees on 1452 citrumelo rootstock. Plant Disease Reporter, v. 46, n. 4, p. 267-268, 1962.

LATADO R.R.; DERBYSHIRE, M.T.V.C.; TSAI, S.M. et al. A obtenção de híbridos somáticos de limão 'Cravo' e tangerina 'Cleópatra'. Pesquisa Agropecuária Brasileira, v.37, n.12, p.1725 -1741, 2002. 
MCCLEAN, A.P.D. Abnormal bud-union between some sweet oranges and rough lemon rootstock: evidence of cause by a transmissible pathogen. In: CONFERENCE OF THE INTERNATIONAL ORGANIZATION OF CITRUS VIROLOGISTS, 6., Tokyo, 1974. Proceedings Richmond: International Organization Citrus Virologists, 1974. p.203-210.

MENDEL, K. Rootstock - scion relationship in Shamouti trees on light soil. Katavim, Rehovt, n.6, p.35-60, 1956.

MENEGHINI, M. Sobre a natureza e transmissibilidade da doença "tristeza" dos citros. O Biológico, v.12, p.285-287, 1946.

MOREIRA, S. Xiloporose. Jornal de Agronomia, v.1, p.217-226, 1938.

MOREIRA, S. Observações sobre a "tristeza" dos citrus ou podridão das radicelas. O Biológico, n.8, p.269-276, 1942.

MOREIRA, S. Cavalos para citros em São Paulo. Revista da Agricultura, v.21, p.206-226, 1946.

MOREIRA, S. Exocortis, outra moléstia de vírus nos laranjais paulistas. 0 Agronômico, v.6, p.10-12, 1954.

MOREIRA, S. A molestia "exocortes" e o cavalo de limoeiro-'Cravo'. Revista da Agricultura, v.30, p.99-112, 1955.

MOREIRA, S. Rangpur lime disease and its relationship to exocortis. In: WALLACE, J. M. (Ed.). Citrus Virus Diseases. Berkeley: University of California Press, 1959. p.134-140.

MOREIRA, S. Clones nucelares: caminho para uma nova citricultura. Revista da Agricultura, v.37, n.2, p. 3-5, 1962. 
MOREIRA, S.; SALIBE, A.A. Nucellar lines in the State of São Paulo, Brazil. In: CONFERENCE OF THE INTERNATIONAL ORGANIZATION OF CITRUS VIROLOGISTS, 3., São Paulo, 1963. Proceedings. Gainesville: International Organization of Citrus Virologists, 1965. p.309-313.

MOREIRA, S.; GURGEL, J.T.A.; ARRUDA, L.F. de. Poliembrionia em Citrus. Bragantia, v.7, n.3, p.69-106, 1947.

MOREIRA, S.; GRANT, T.J.; SALIBE A.A. et al. Tristeza tolerant rootstocks - their behavior after twelve years in orchard. In: CONFERENCE OF THE INTERNATIONAL ORGANIZATION OF CITRUS VIROLOGISTS, 3., São Paulo, 1963. Proceedings. Gainesville: International Organization of Citrus Virologists, 1965. p.18-24.

MOURÃO FILHO, F.A.A.; MENDES, B.M.J. Hibridação somática para melhoramento de citros em São Paulo. In: SEMINARIO INTERNACIONAL DE CITROS: MELHORAMENTO, 7. Bebedouro, 2002. Anais. Bebedouro: Estação Experimental de Citricultura de Bebedouro, 2002. p.134-140.

MULLER, G.W.; RODRIGUEZ, O.; COSTA, A.S. A tristeza vírus complex severe to sweet orange varieties. In: CONFERENCE OF THE INTERNATIONAL ORGANIZATION OF CITRUS VIROLOGISTS, 4., Catania, 1966. Proceedings. Gainesville: International Organization of Citrus Virologists, 1968. p.64-71.

MULLER, G.W.; LARANJEIRA, F.F.; POMPEU JUNIOR, J. et al. Epidemias de declínio dos citros em combinações com tangerina 'Cleópatra' como porta-enxerto no Estado de São Paulo. Fitopatologia Brasileira, v.22, p.345, (Supl.), 1997.

MULLER, G.W., NEGRI, J.D.; AGUILAR-VILDOSO, C. I. et al. Morte súbita dos citros: uma nova doença na citricultura brasileira. Laranja, v.23, n.2, p.371-386, 2002. 
NAURIYAL, J.P.; SHANNON, L. M.; FROLICH, E.F. Eureka lemon - trifoliate orange: incompatibility. Proceedings. American Society Horticultural Science, v. 72, p. 273-283, 1958.

O'BANNON J.H.; FORD, H.W. Resistance in citrus rootstocks to Radopholus similis and Tylenchulus semipenetrans (Nematoda). In: INTERNATIONAL CITRUS CONGRESS, Orlando, 1977. Proceedings Orlando: International Society of Citriculture, 1977, p. 544-549.

OGATA, T.; SOUZA, M.; SANTOS, M.G.F.M. Poliembrionia, efeitos do nitrato de potássio e da permanência de sementes no germinador, na separação dos embriões de citros. In: CONGRESSO BRASILEIRO DE FRUTICULTURA, 6., Recife, 1981. Anais. Recife: Sociedade Brasileira de Fruticultura, 1981. p.693-701.

OLSON, E.O.; COOPER, W.C.; MAXWELL, N. et al. Survival, size and yield of xyloporosis and exocortis infected old line red grapefruit trees on 100 rootstocks. Journal Rio Grande Valley Horticultural Society, n.16, p.44-51, 1962.

PEYNADO, A.; YOUNG, R. Relation of salt tolerance to cold hardiness of 'Redblush' grapefruit and Valencia orange trees on various rootstocks. In: INTERNATIONAL CITRUS SYMPOSIUM, 1., Riverside, 1968. Proceedings. Riverside: University of California, 1969. p. 1793-1802.

PIO, R.M.; POMPEU JUNIOR, J. Polyembriony in 26 trifoliate-type rootstocks. In: INTERNATIONAL CITRUS CONGRESS, São Paulo, 1984. Proceedings. São Paulo: International Society of Citriculture, 1984. p.24-25.

POMPEU JUNIOR, J. Porta-enxertos para citros. In: RODRIGUEZ, O., VIEGAS, F., POMPEU JUNIOR, J., AMARO, A. A. (Ed.). Citricultura Brasileira. Campinas: Fundação Cargill, 1991, v.1, p.265-280. 
POMPEU JUNIOR, J. Seleção de novos porta-enxertos para as principais cultivares de laranjas. Relatório científico apresentado ao CNPq, mar. 1996. 21p.

POMPEU JUNIOR, J. Seleção de novos porta-enxertos para as principais cultivares de laranjas. Relatório científico apresentado a FAPESP, dez. 2000. 27p.

POMPEU JUNIOR, J. Porta-enxertos para citros potencialmente ananicantes. Laranja, v.22, p.147-155, 2001a.

POMPEU JUNIOR, J. Rootstocks and scions in the citriculture of the São Paulo State. In: INTERNATIONAL CONGRESS OF CITRUS NURSERYMEN, 6., Ribeirão Preto, 2001. Proceedings. Bebedouro: Estação Experimental de Citricultura de Bebedouro, 2001b. p. 75-82.

POMPEU JUNIOR, J.; BLUMER, S. Incompatibilidade de laranjeira 'Valência' enxertada em híbrido de limão 'Cravo' x citrange Carrizo. In: SEMINÁRIO INTERNACIONAL DE CITROS: MELHORAMENTO, 7., Bebedouro, 2002. Anais. Bebedouro: Estação Experimental de Citricultura de Bebedouro, 2002a, p.126.

POMPEU JUNIOR, J.; BLUMER, S. Produção de laranjeiras 'Valência' enxertadas em seleções de citrumelo. In: SEMINARIO INTERNACIONAL DE CITROS, 7., Bebedouro, 2002. Anais. Bebedouro: Estação Experimental de Citricultura de Bebedouro, 2002b, p. 127.

POMPEU JUNIOR, J., DONADIO, L. C.; FIGUEIREDO, J.O. Incompatibilídade entre o tangor Murcote e trifoliata. Instituto Agronômico, jun. 1972. 5p. (Circular 15).

POMPEU JUNIOR, J.; FIGUEIREDO, J.O.; TEÓFILO SOBRINHO, J. Incompatibilidade entre limoeiro Siciliano e híbridos de trifoliata. Ciência e Cultura, v.26, n.7, p.581, 1974 
POMPEU JUNIOR, J.; DE NEGRI, J.D.; BERETTA, M.J.A.G. Relatório de viagem de estudos as citriculturas dos Estados da Flórida e Califórnia. Campinas, 1989. $62 p$.

POMPEU JUNIOR, J.; TEÓFILO SOBRINHO, J.; BLUMER, S. Seleções de trifoliata como porta-enxertos para laranjeiras 'Valência'. (compact disc) In: CONGRESSO BRASILEIRO DE FRUTICULTURA, 17., Belém, 2002. Anais. Belem: Sociedade Brasileira de Fruticultura, 2002 c.

POMPEU JUNIOR, J.; BLUMER, S.; LARANJEIRA, F.F. Novos híbridos de trifoliata para a citricultura paulista. Laranja, v.23, n.2, p.413-425, 2002a.

POMPEU JUNIOR, J.; LARANJEIRA, F.F.; BLUMER, S. Laranjeiras 'Valência' enxertadas em hibridos de trifoliata. Scientia Agricola, v.59, p. 93-97, 2002b.

POMPEU JUNIOR, J.; SALVA, R; BLUMER, S. Copas e porta-enxertos nos viveiros de mudas cítricas do Estado de São Paulo. Laranja, v.25, n.2, 2004.(em impressão).

PORTO, O.M.; SOUZA, E.L.S. Comportamento da laranjeira 'Valência' sobre 36 porta-enxertos no Rio Grande do Sul. In: CONGRESSO BRASILEIRO DE FRUTICULTURA, 7., Florianópolis, 1983. Anais. Florianópolis: Sociedade Brasileira de Fruticultura, 1984. p.592-599.

PRASAD, M.B.N.V.; RAVISHNKAS, H.R. A note on polyembryonic studies in different cultivars and selections of Rangpur lime. Haryana Journal Horticultural Science, v.11, n.3/4, p.213-214, 1982.

RABE, E.; COETZEE, J.G.K.; LEE, A.T.C. Rootstocks for Southern Africa: an overwiew. In: INTERNATIONAL CONGRESS OF CITRUS NURSERYMEN, 4., Nelspruit, 1993. Proceedings. Nelspruit: South African Citrus Nurserymen's Association, 1993. p. 266-277. 
RELATÓRIO DE ATIVIDADES 2003. Estudo de 16 porta-enxertos para a laranjeira Homosassa. Bebedouro: Fundação de Pesquisas Agroindustriais de Bebedouro, Estação Experimental de Citricultura. 2003. p.11.

RODRIGUEZ, O. Estudo de espaçamento, porta-enxerto e adubação para a laranjeira Baianinha. 1972. 82p. Tese (Doutorado em Agronomia) - Escola Superior de Agricultura "Luiz de Queiroz", Universidade de São Paulo.

RODRIGUEZ, O.; ROSSETTI, V.; MOREIRA, C.S. et al. Declínio de plantas cítricas em São Paulo. In: CONGRESSO BRASILEIRO DE FRUTICULTURA, 5., Pelotas, 1979. Anais. Pelotas: Sociedade Brasileira de Fruticultura, 1979. p.927-932.

ROISTACHER, C.N. Graft-transmissible diseases of citrus. Roma: FAO, 1991. 286p.

ROOSE, M.L. Dwarfing rootstocks for citrus. INTERNATIONAL CONGRESS OF CITRUS NURSERYMEN, 2., Valencia, 1986. Proceedings. Valencia: International Society of Citrus Nurserymen, 1986. p.2-8.

ROOSE, M.L. Porta-enxertos de citros na California. In: SEMINÁRIO INTERNACIONAL DE CITROS: PORTA-ENXERTOS, 1., 1990, Bebedouro. Anais. Jaboticabal: Funep, 1990. p.51-60.

ROUSE, R.E.; SHERROD, J.B. Optimum temperature for citrus seed germination. Proceedings. Gainesville: Florida State Horticultural Society, v.109,1996. p.132-135.

SALIBE, A.A. Curso de especialização em citricultura a nivel de pós-graduado. Recife: Sudene, dez.1969. 177p. 
SALIBE, A.A.; MOREIRA, S. Reaction of types of citrus as scion and as rootstocks to xyloporosis virus. In: CONFERENCE OF THE INTERNATIONAL ORGANIZATION OF CITRUS VIROLOGISTS, 3., São Paulo, 1963. Proceedings. São Paulo: International Organization of Citrus Virologists, 1965. p.238-241.

SALIBE, A.A.; CEREDA, E. Poliembrionia em variedades de citros. In: Reunião Anual da Sociedade Brasileira para o Progresso da Ciência , Salvador,1970. Resumos. São Paulo: Sociedade Brasileira para o Progresso da Ciência, 1970. p.208.

SAVAGE, E.M.; GARDNER, F.E. The origin and history of Troyer and Carrizo citranges. Citrus Industry, v.46, n.2, p.5-7, 1965.

SETZER, J. Atlas climático e ecológico do Estado de São Paulo. São Paulo: Comissão Interestadual da Bacia Paraná-Uruguai, 1966. 61p.

SHANNON, L M; FROLICH, E.F.; CAMERON, S.H. Characteristics of Poncirus trifoliata selections. Journal American Society Horticultural Science, v.76, p.163-169, 1960.

SIVIERO, A. Métodos de inoculação da Phytophthora parasítica e mapeamento de QTLs de resistência em híbridos de Citrus sunki vs. Poncirus trifoliata a gomose. Botucatu, 2001. 117 p. Tese (Doutorado) - Faculdade de Ciências Agronômicas, Universidade Estadual Paulista "Julio de Mesquita Filho".

SOARES FILHO, W.S.; MOREIRA, C.S.; CUNHA, M.A.P. et al.. Poliembrionia e freqüência de híbridos em Citrus spp. Pesquisa Agropecuária Brasileira, v.35, n.4, p.857-864, 2000. 
SOARES FILHO, W.S.; ALVES, A.A.C.; OLIVEIRA, A.A.R. et al. Programa de melhoramento genético de citros da Embrapa-Mandioca e Fruticultura: obtenção de híbridos. In: SEMINÁRIO INTERNACIONAL DE CITROS: MELHORAMENTO, 7. Bebedouro, 2002. Anais. Bebedouro: Estação Experimental de Citricultura de Bebedouro, 2002, p.96-108.

STANNARD, M.C. Citrus rootstocks in Australia. In: WORLD CONGRESS OF CITRICULTURE, 1., Valencia, 1973. Proceedings. Murcia: International Society of Citriculture, 1975. p.191-193.

TEÓFILO SOBRINHO, J.; POMPEU JUNIOR, J.; FIGUEIREDO, J.O. Adensamento de plantio da laranjeira 'Valência' sobre trifoliata: resultados de 18 anos de colheitas. Laranja, v.13, n.2, p.435-455, 1992.

TEÓFILO SOBRINHO, J.; POMPEU JUNIOR, J.; FIGUEIREDO, J.O. et al Espaçamentos para a laranjeira 'Valência' enxertada sobre trifoliata na região de Aguaí, SP. Laranja, v.16, n.1, p.105-117, 1995.

VASCONCELLOS, P.W.C. Estudo comparativo da laranjeira Bahia Comum sobre cinco differentes porta-enxertos. Boletim da Agricultura, n.40, p.597-621, 1939.

WUTSCHER, H.K., OLSON, E.O.; SHULL, A.V. et al. Leaf nutrient levels, chlorosis, and growth of young grapefruit trees on 16 rootstocks grown on calcareous soils. Journal American Society Horticultural Science, v.95, n.3, p.259-261, 1970.

WUTSCHER, H.K.; SCHWARZ, R.E.; CAMPIGLIA, H.G.; MOREIRA, C.S.; ROSSETTI, V. "Blight" like Citrus trees declines in South America and South Africa. Hortscience, v.15, n.5, p.588-590, 1980. 
YAMAMOTO, P.T.; JESUS JUNIOR, W.C.; BASSANEZI, R.B. et al. Transmission of the agent inducing symptoms of citrus sudden death by graft inoculation under insect proof conditions. Fitopatologia Brasileira, v.28, p.265, (Supl.) 2003.

YOUNG, R.H. The effects of rootstocks on citrus cold hardiness. In: INTERNATIONAL CITRUS CONGRESS, Orlando, 1977. Proceedings. Gainesville: International Society of Citriculture, 1977. p.518-522. 
APÊNDICES 


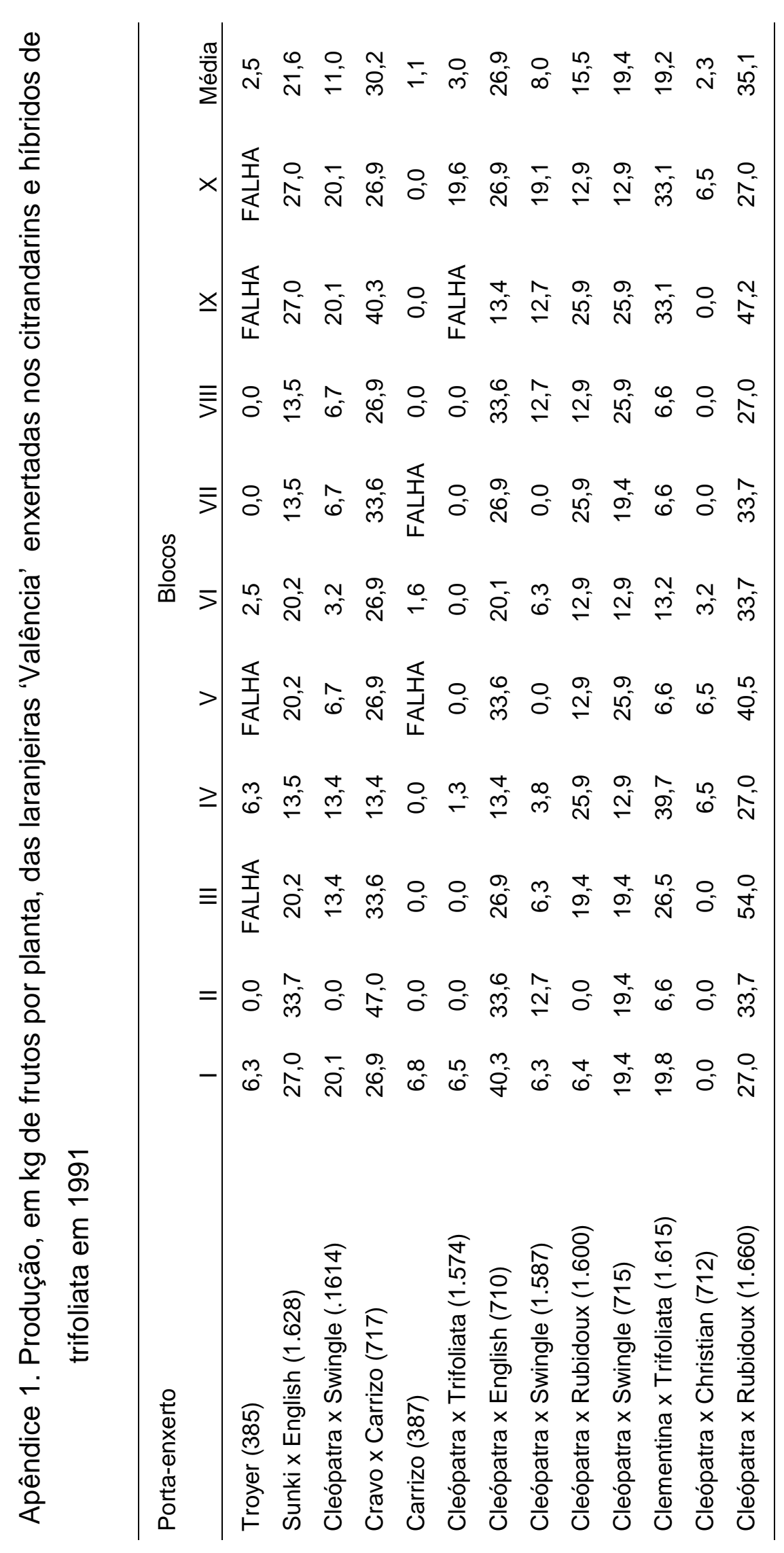




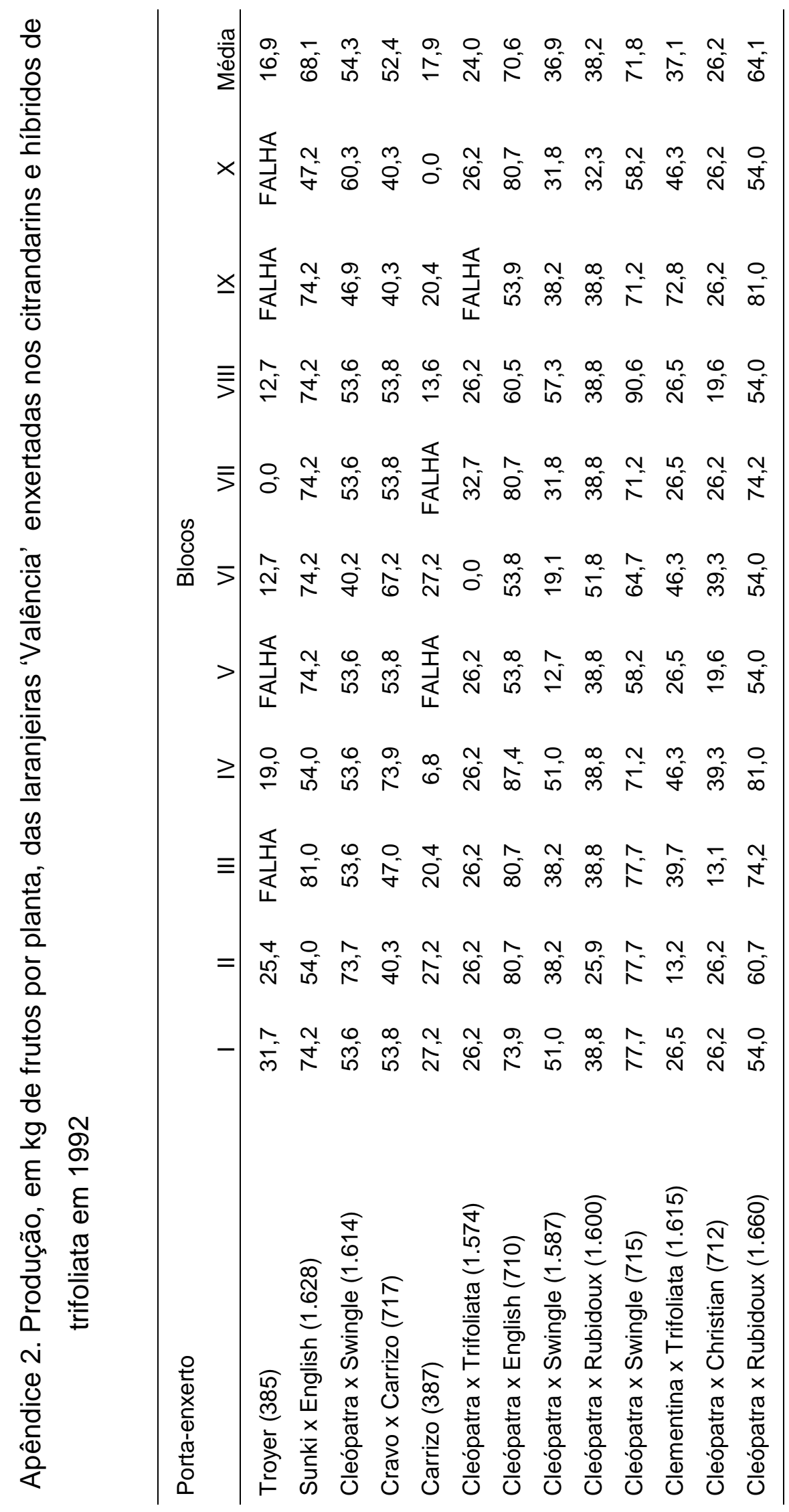




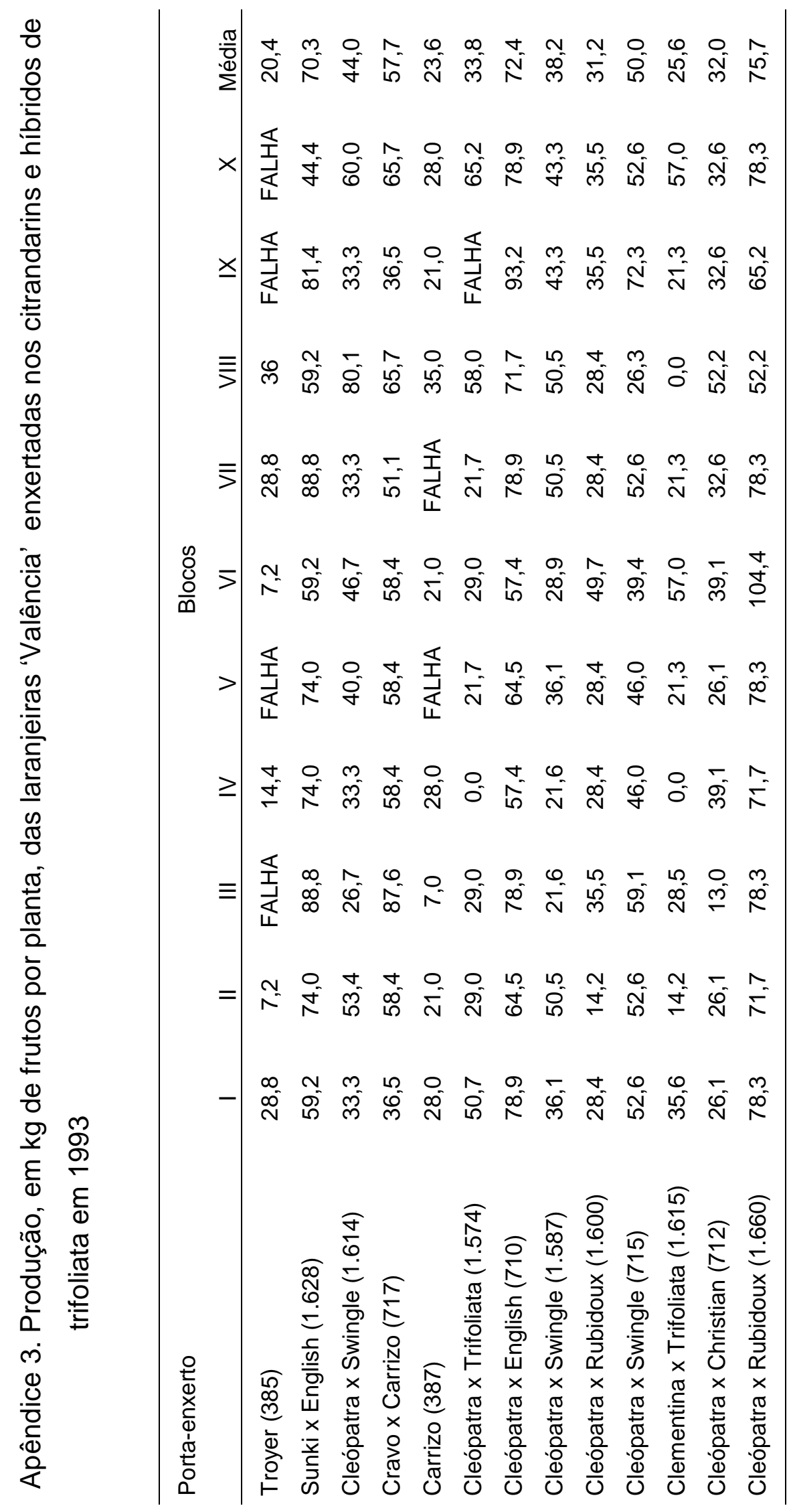




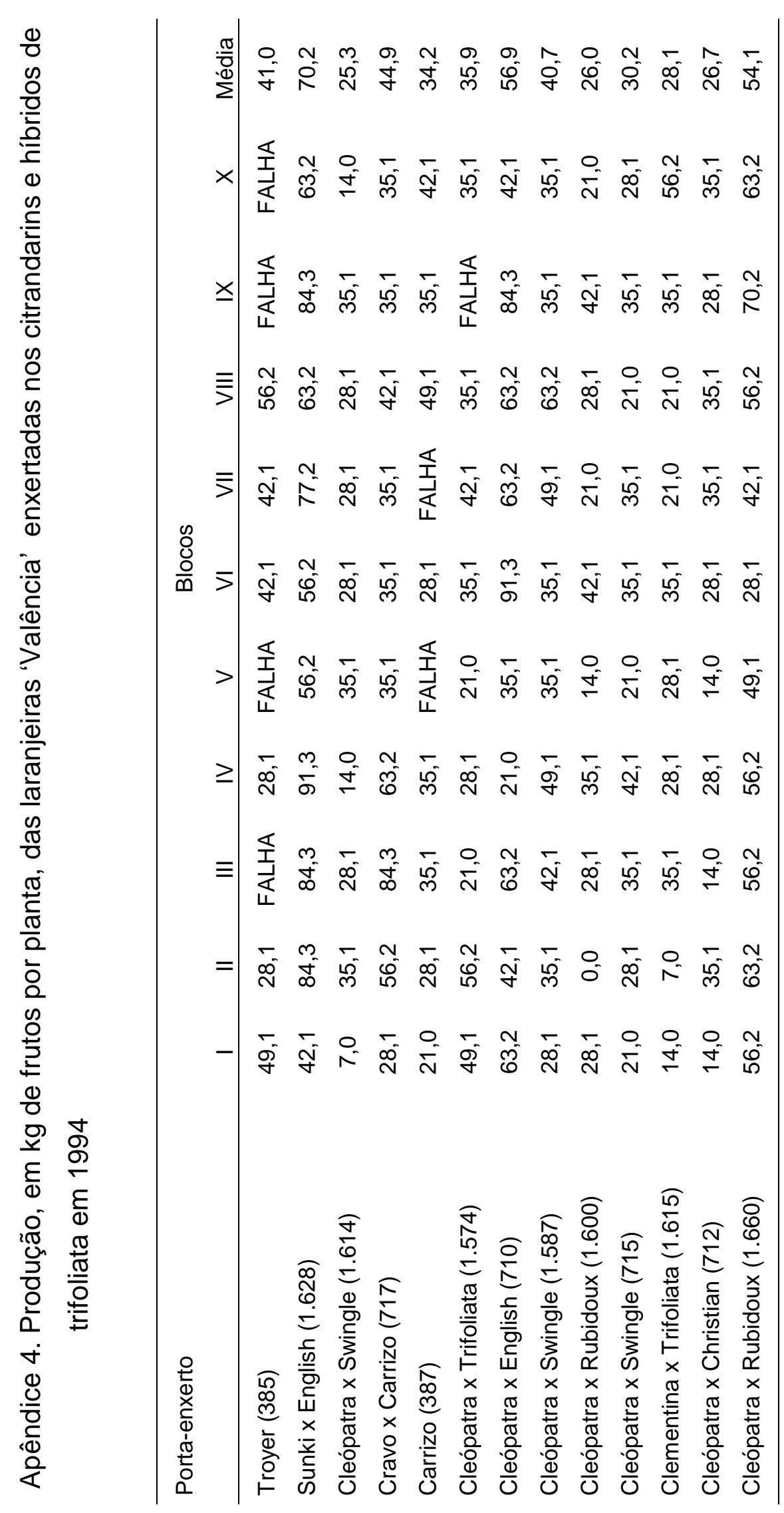




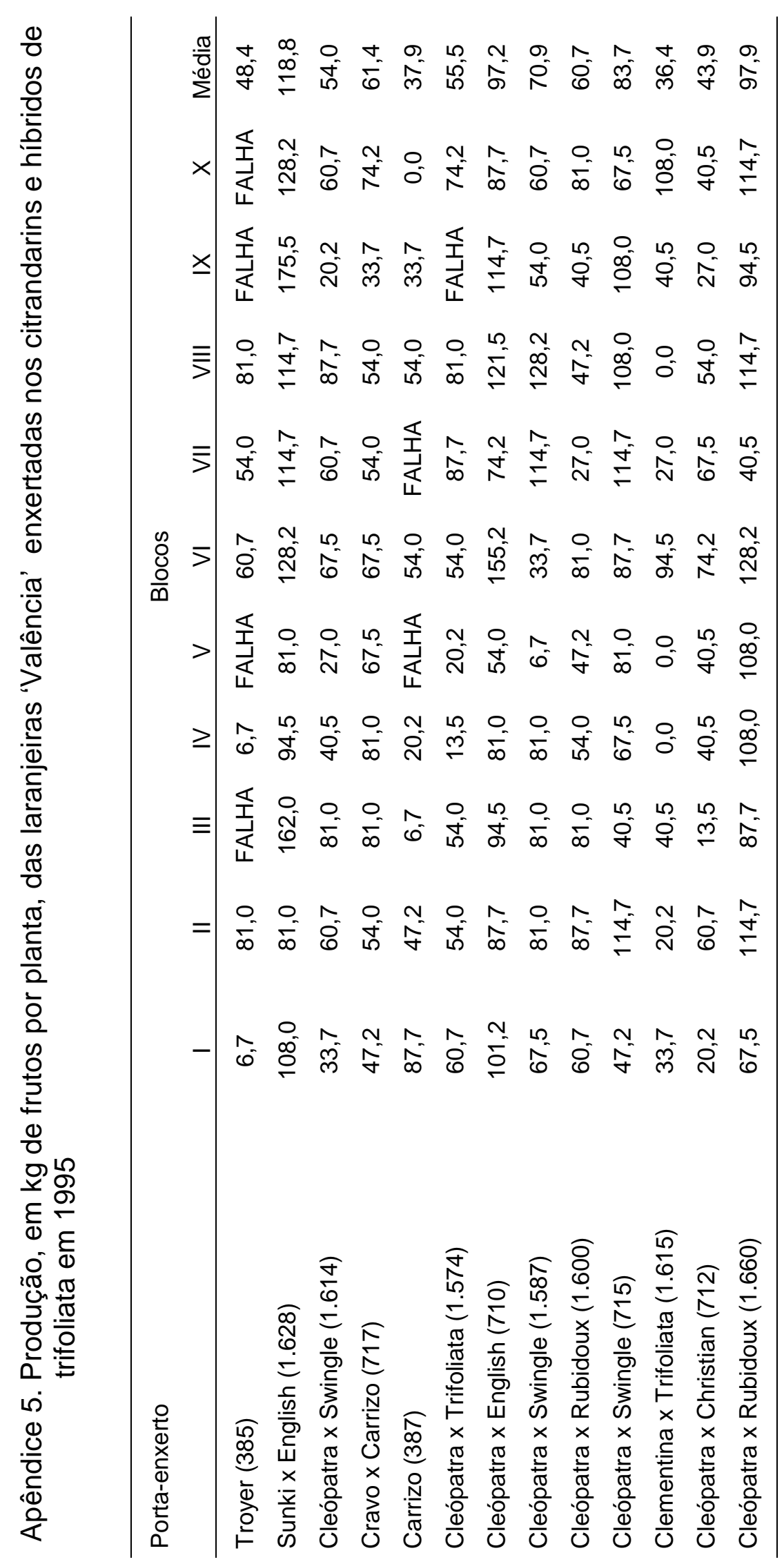




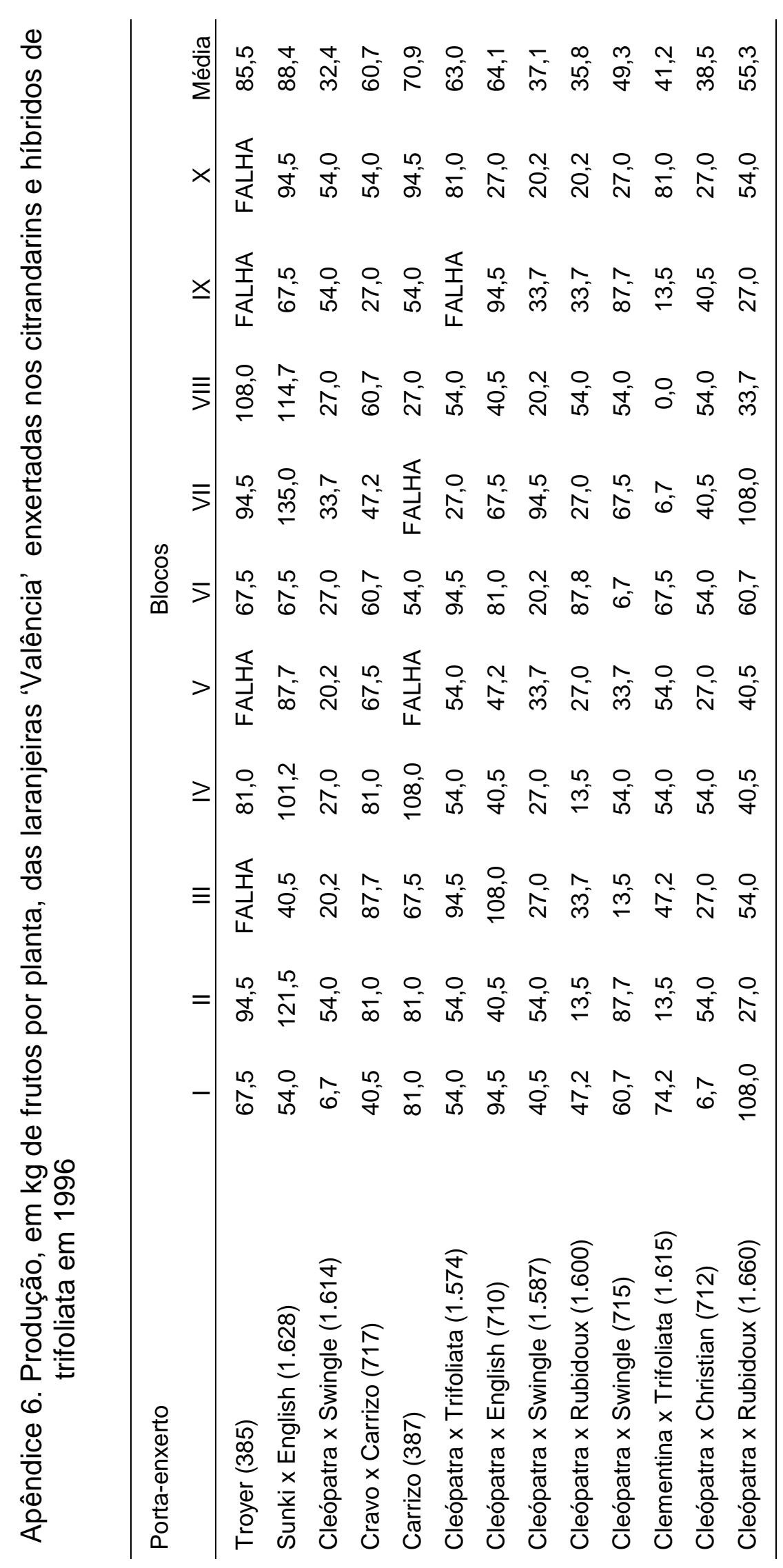




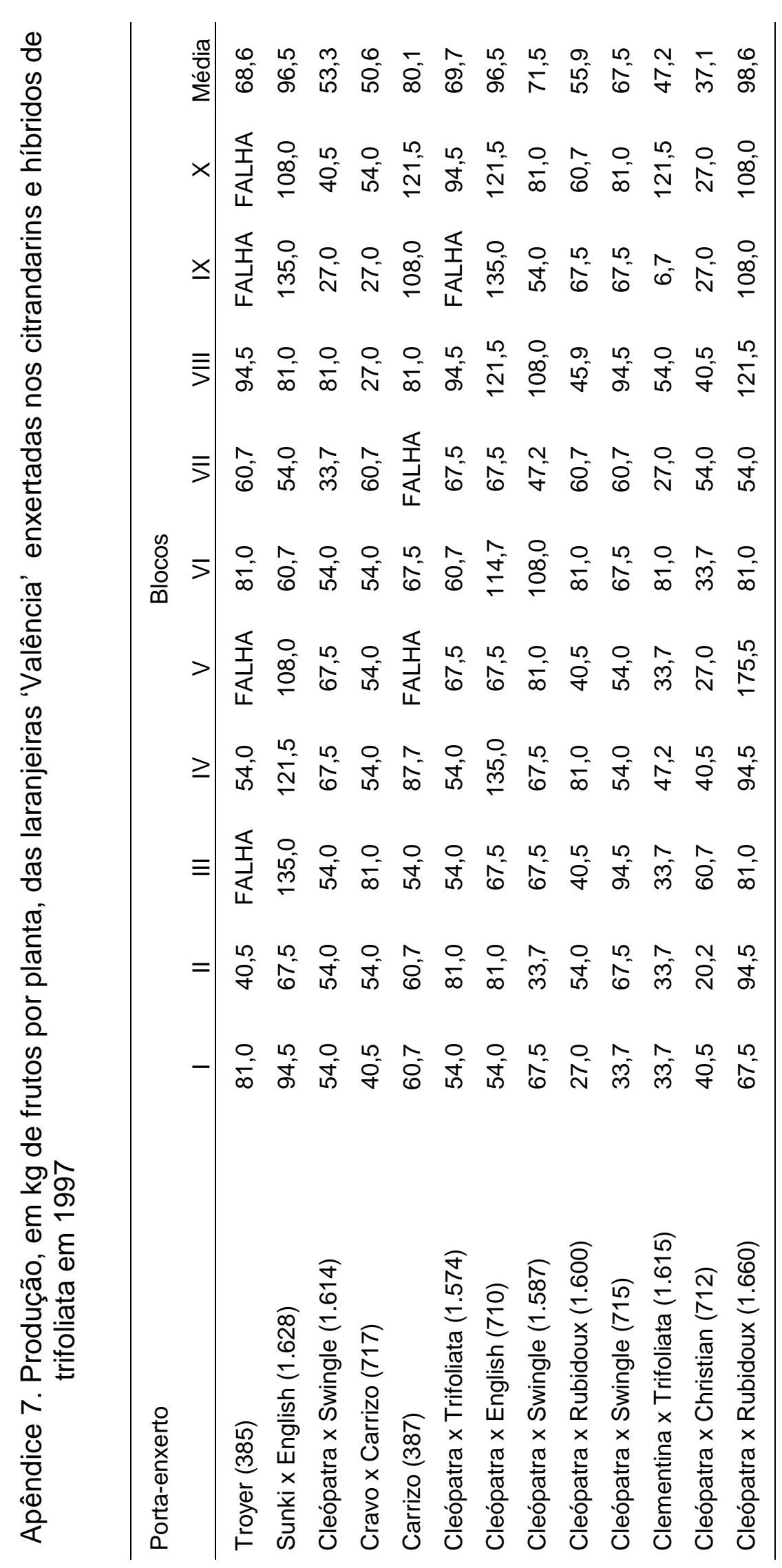




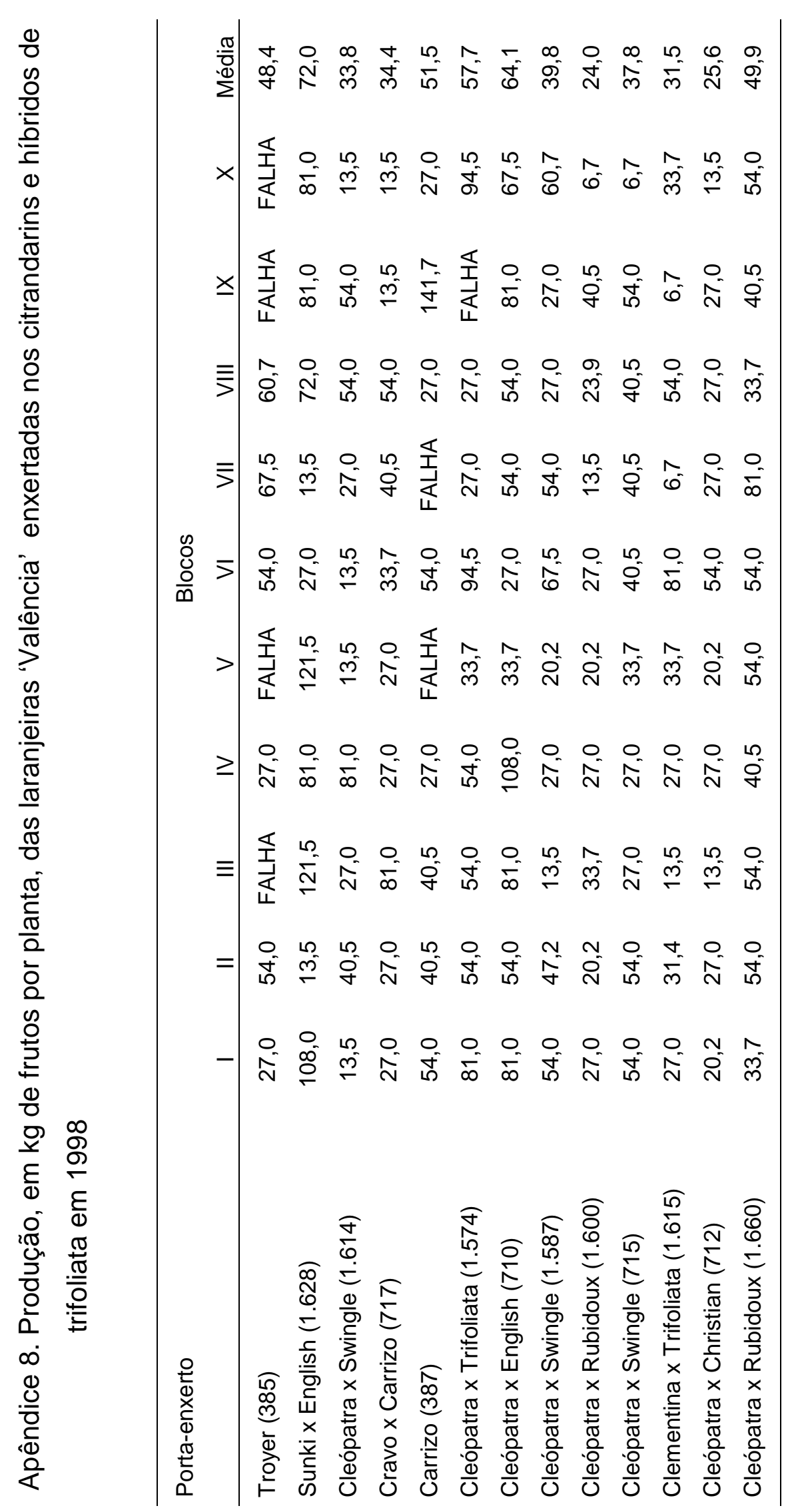




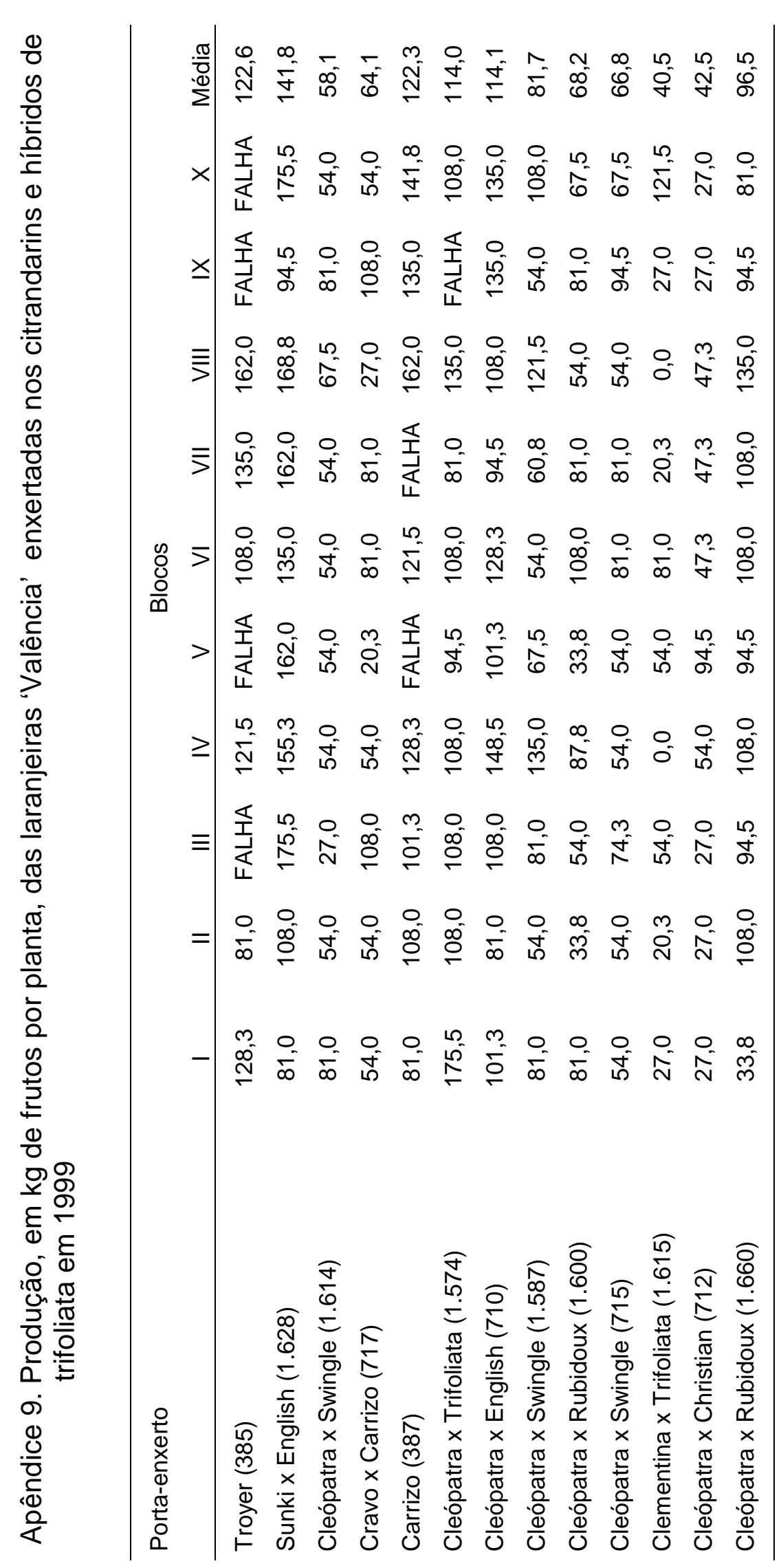




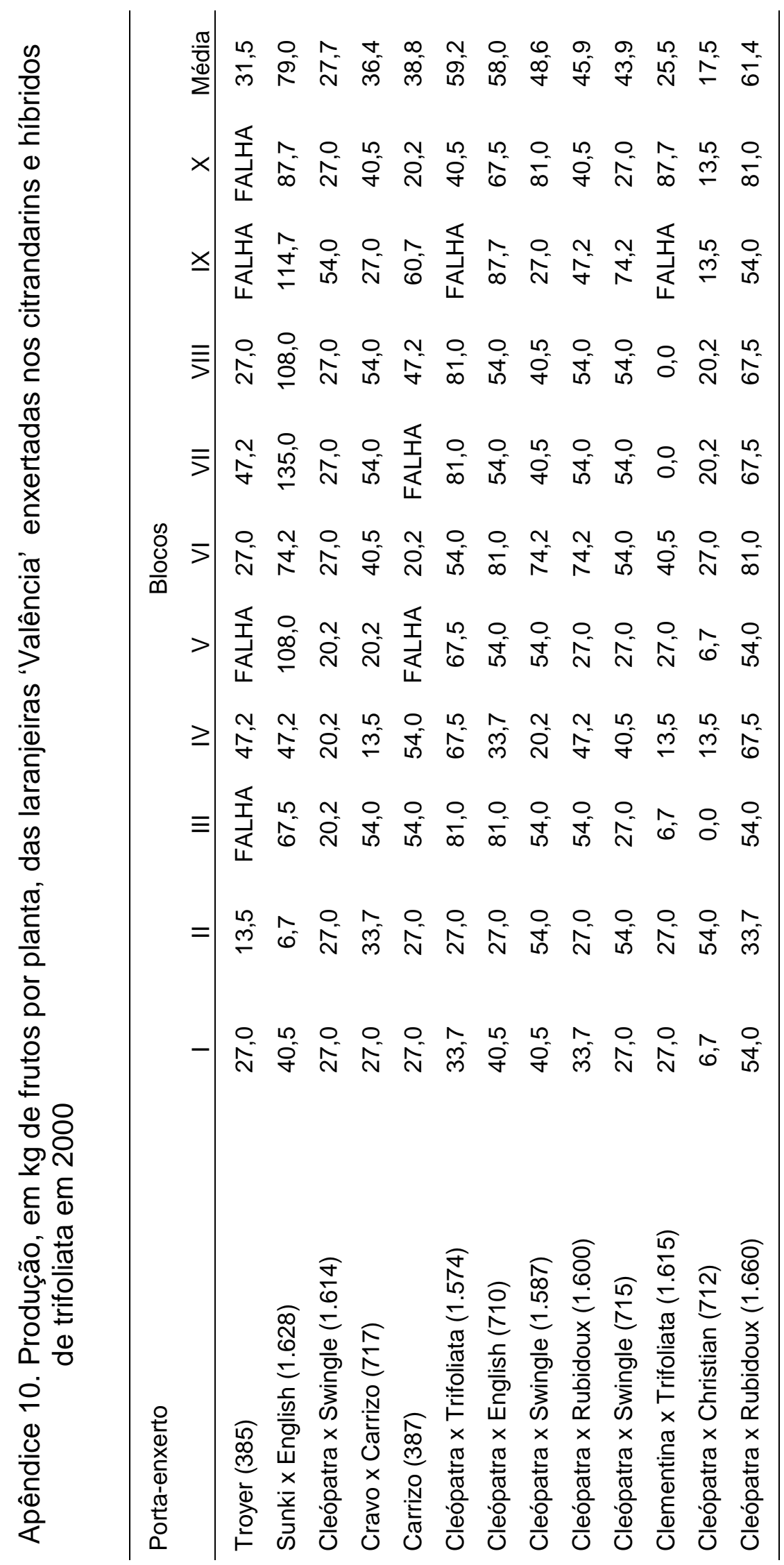




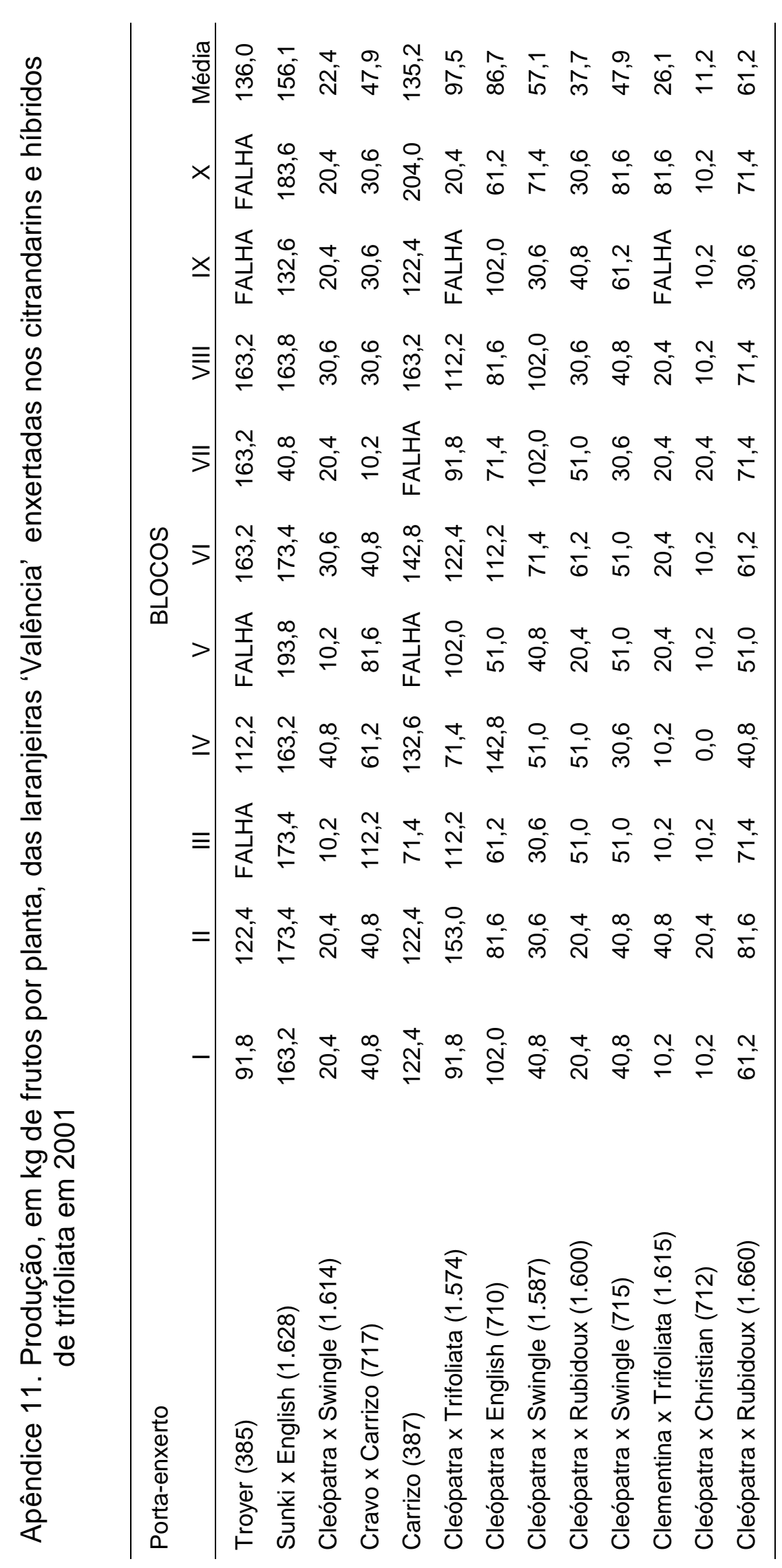




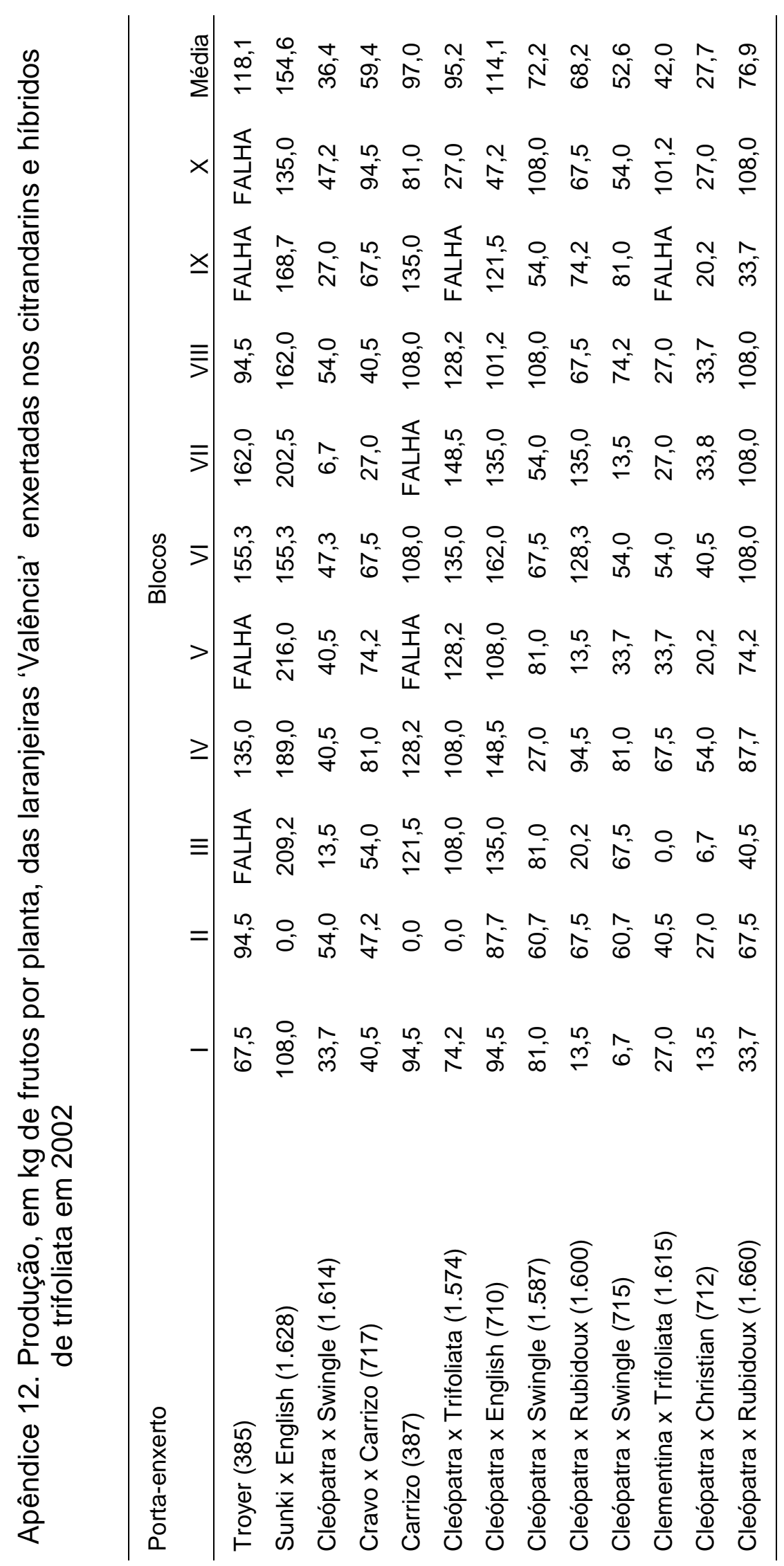




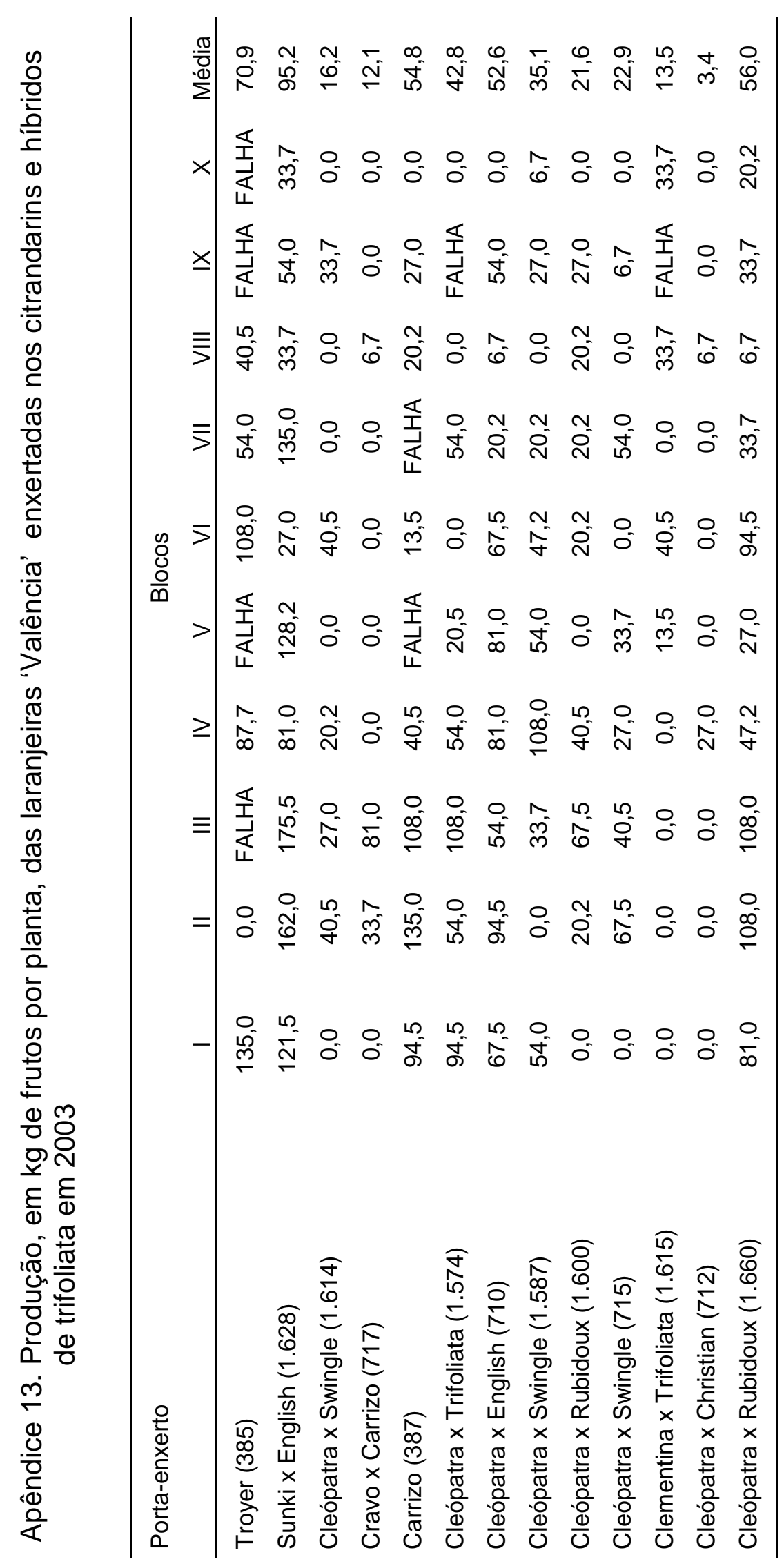




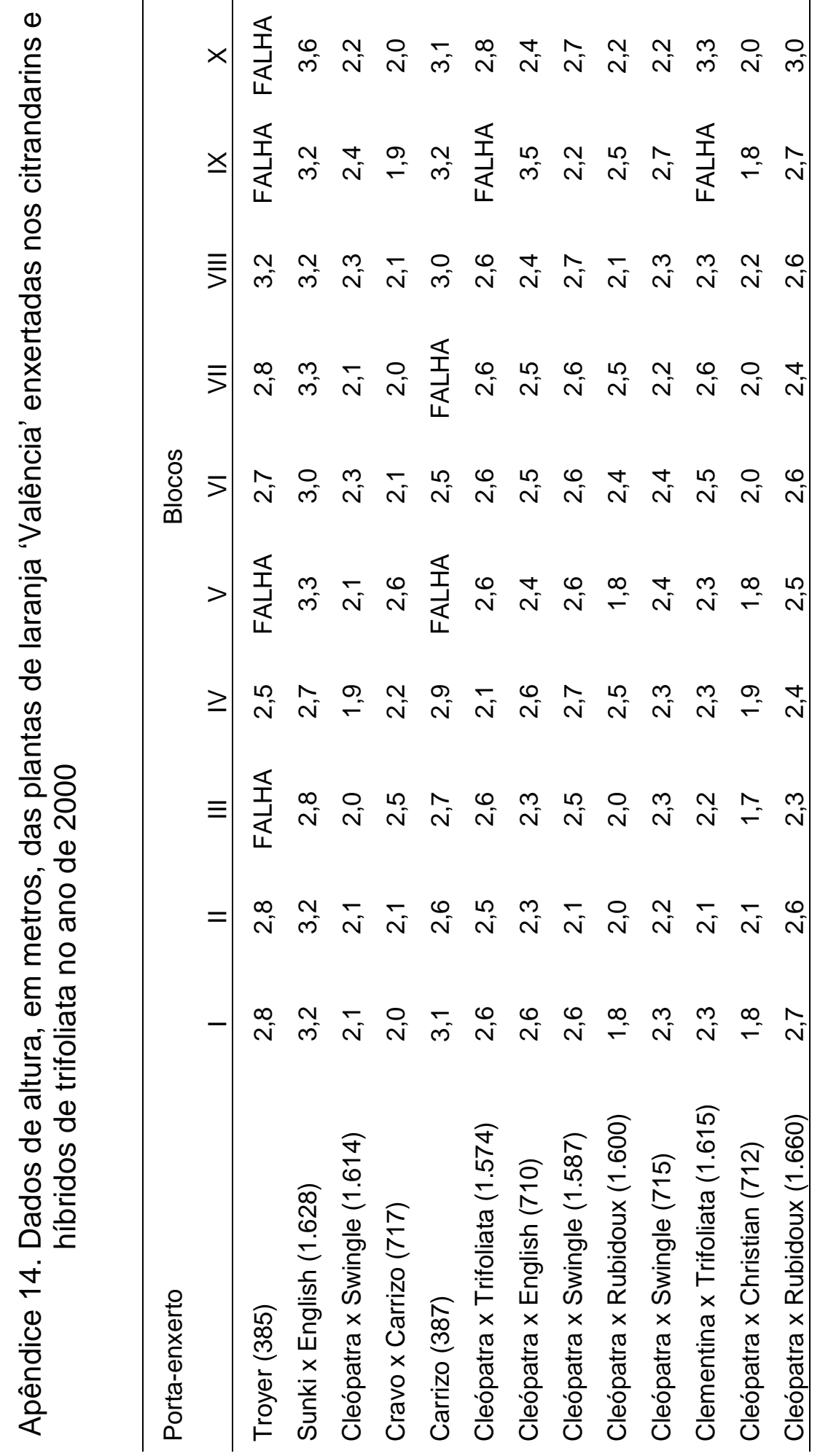




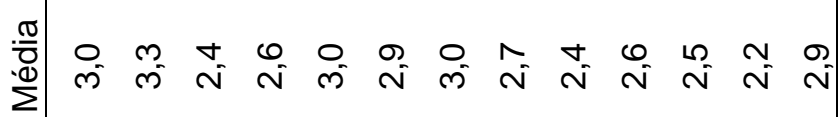

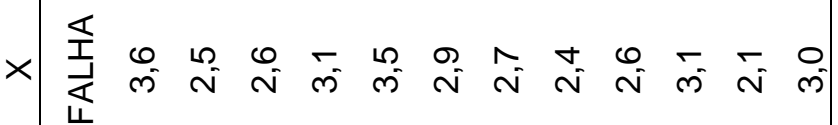

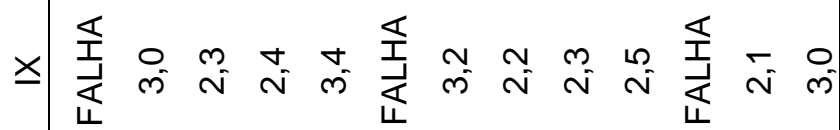

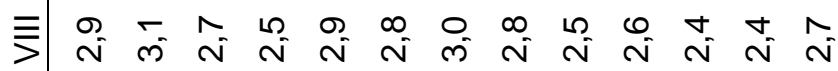

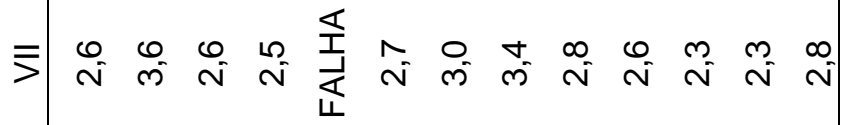

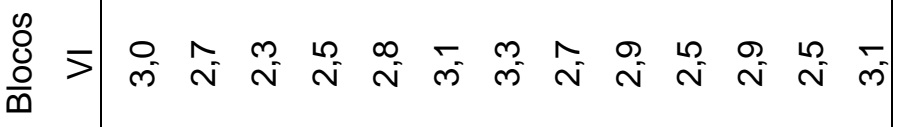

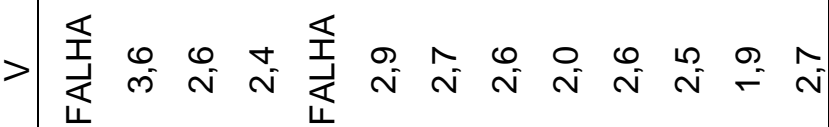

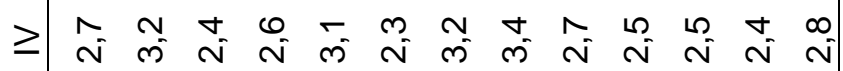

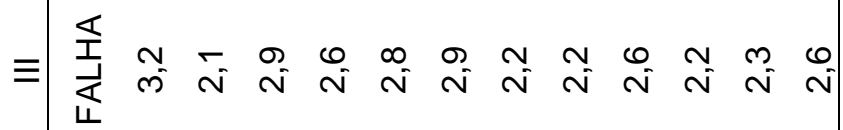

in

웡

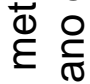

$\frac{\varepsilon}{1)}$ 으

Oำ

(1)

ह

응

응 웅

응음

ํํํ 을

เి

ه

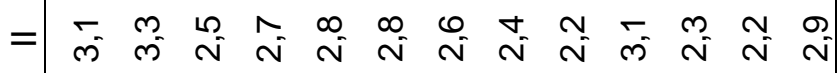

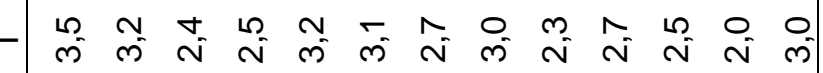

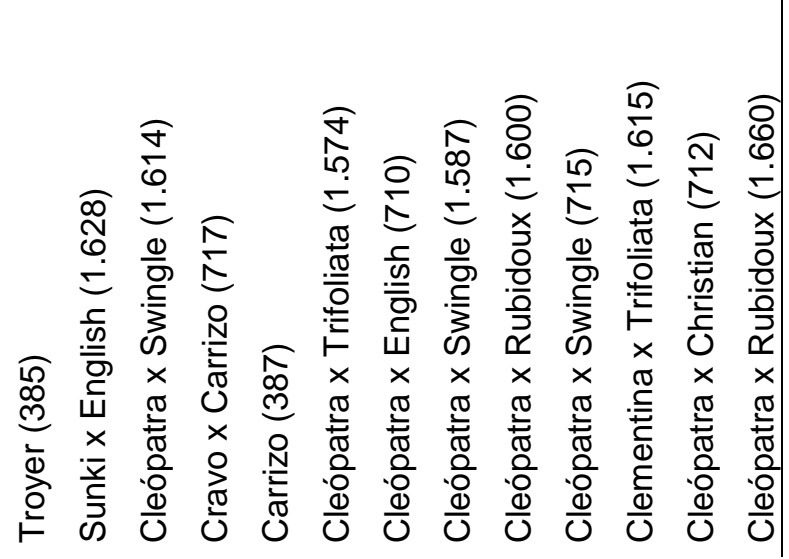




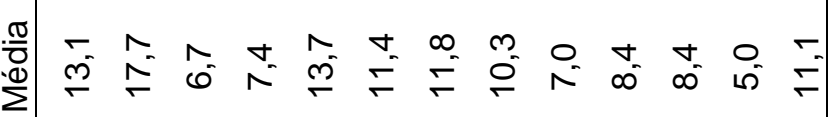

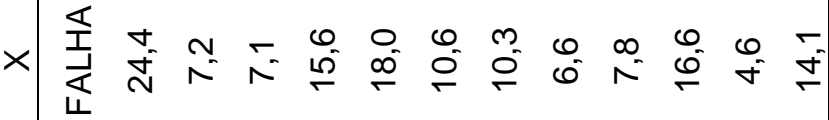

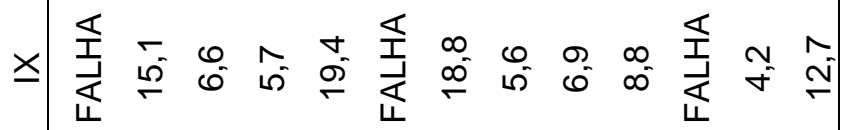

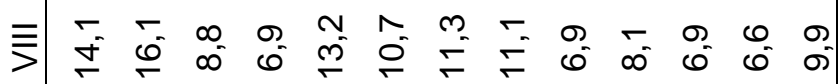

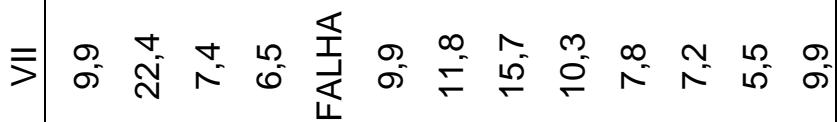

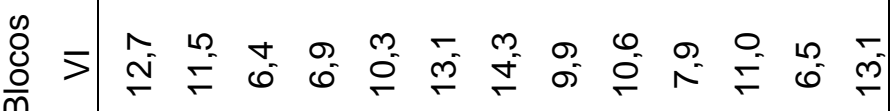

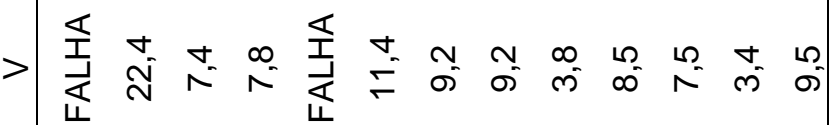

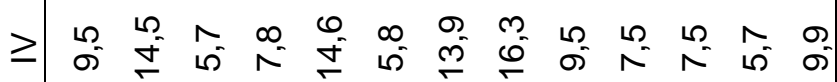

ชั $\frac{0}{\sigma}$

की

을

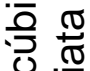

⿻

(1)

ฮ)

동ํㅇ

Фీ 을

高 $\frac{2}{0}$

$>\mathscr{C}$

응 $\frac{\sqrt{\frac{1}{\sigma}}}{\sqrt{0}}$

๓

ชั

6

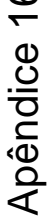

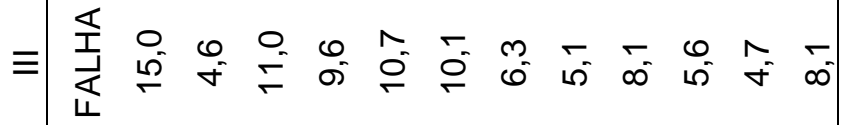

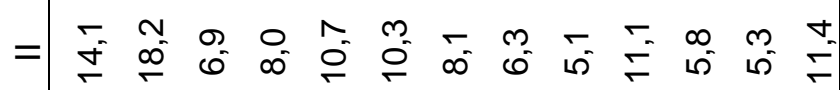

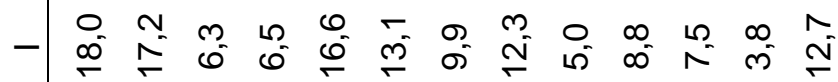

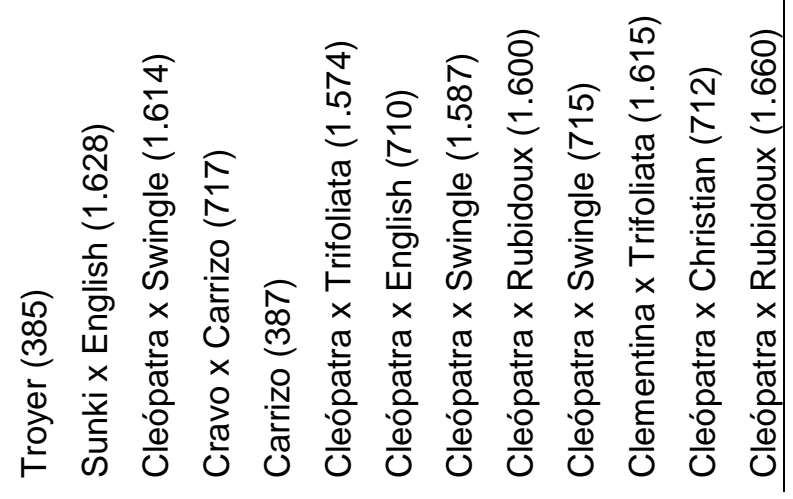




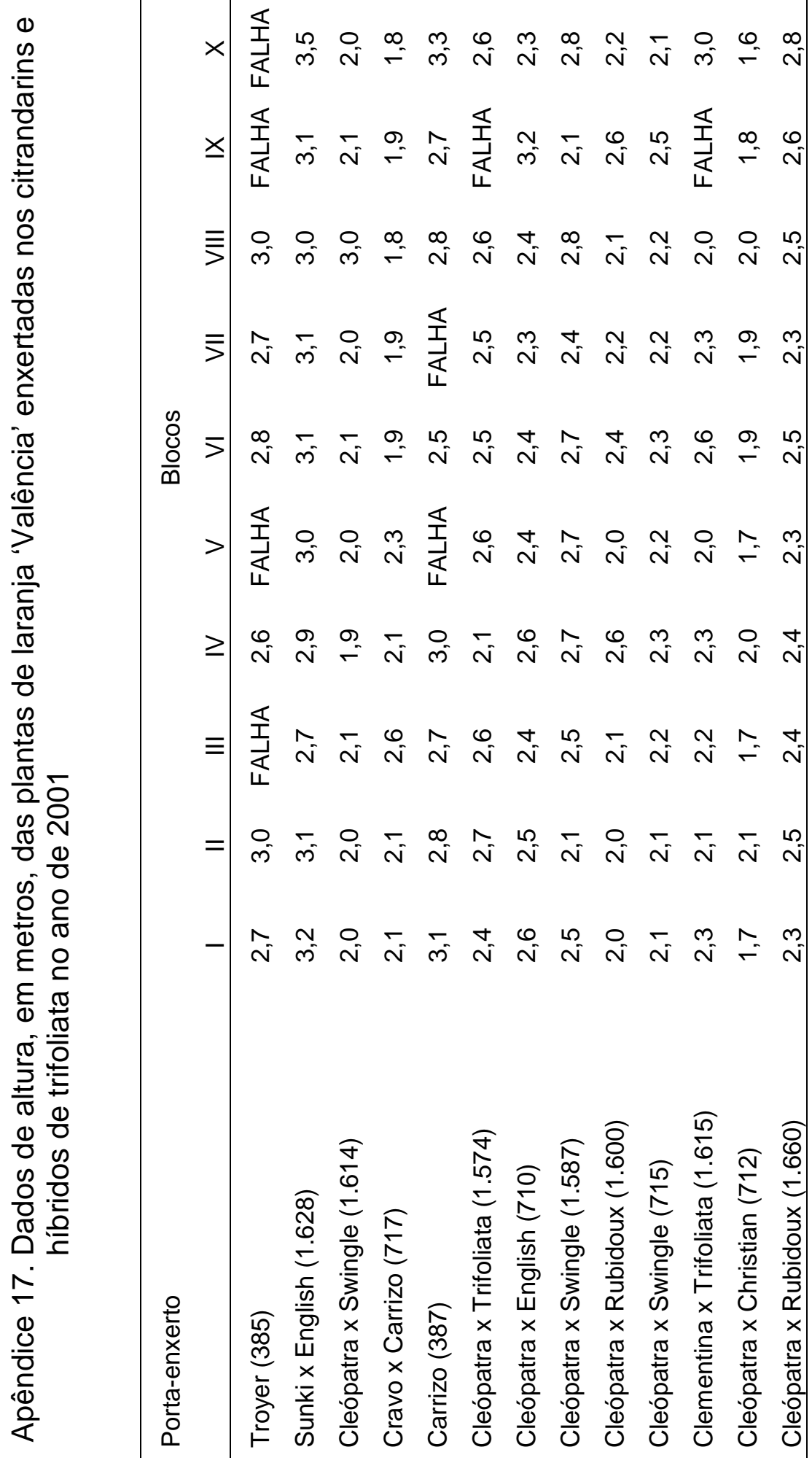




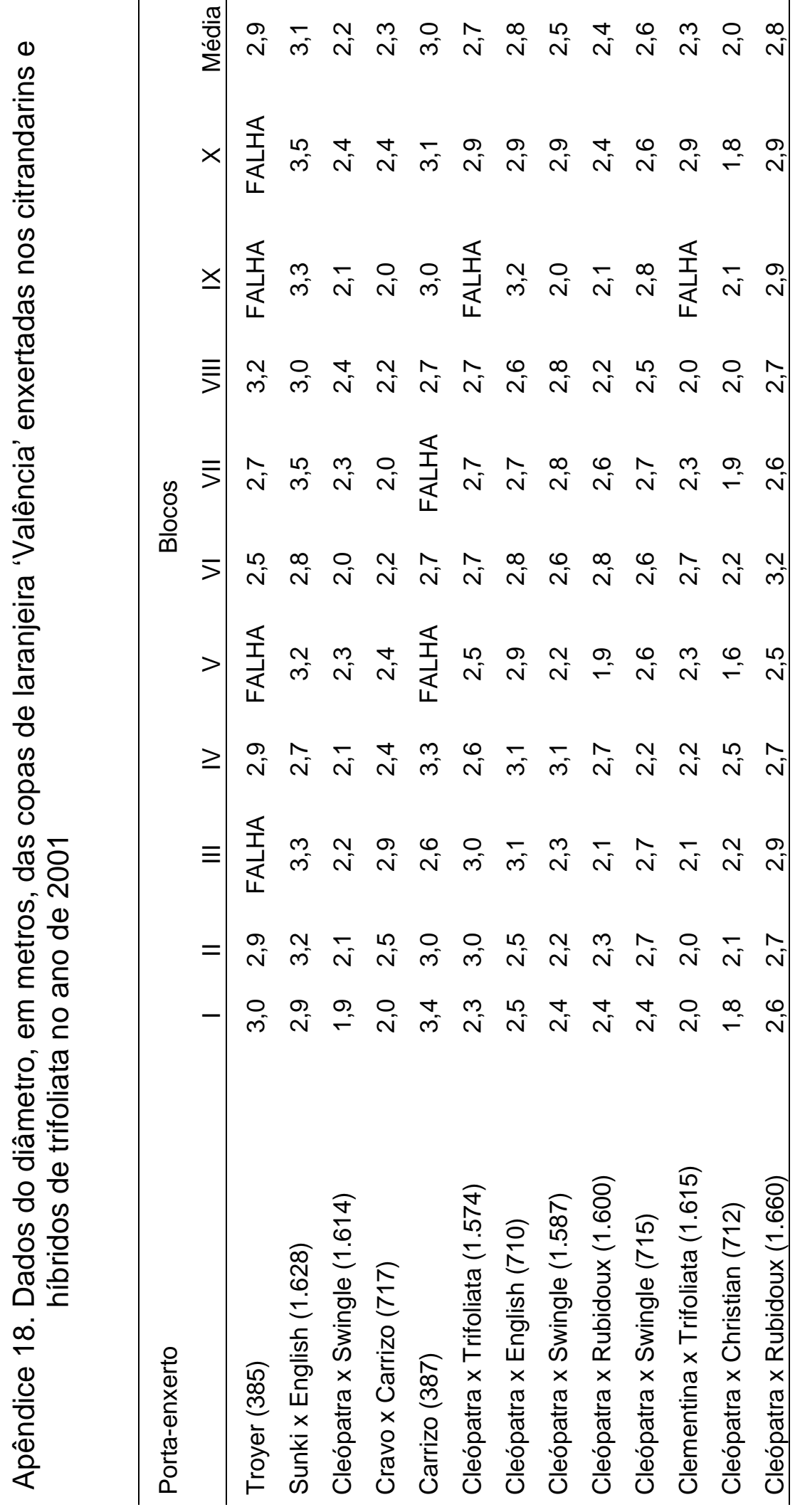




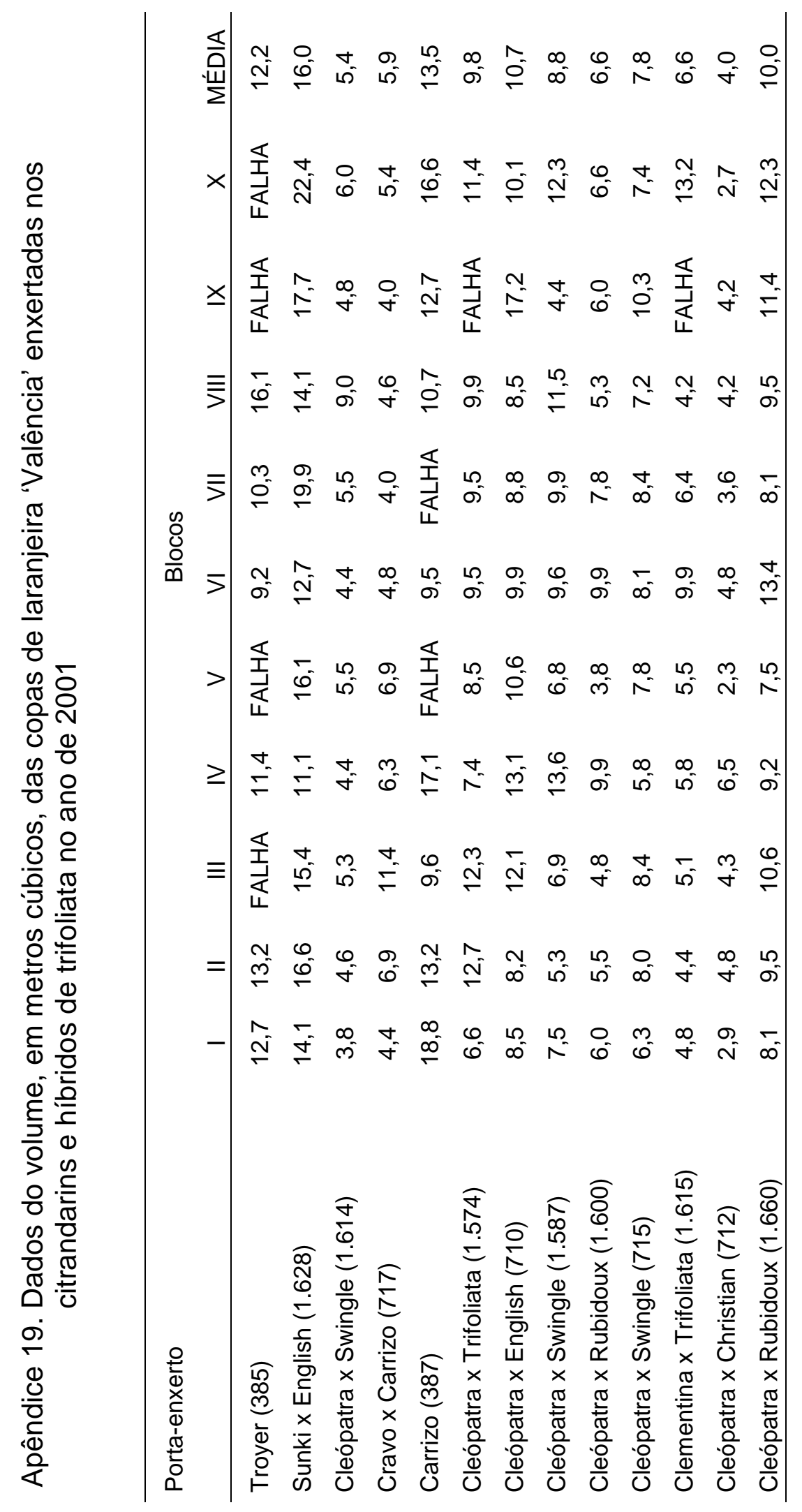




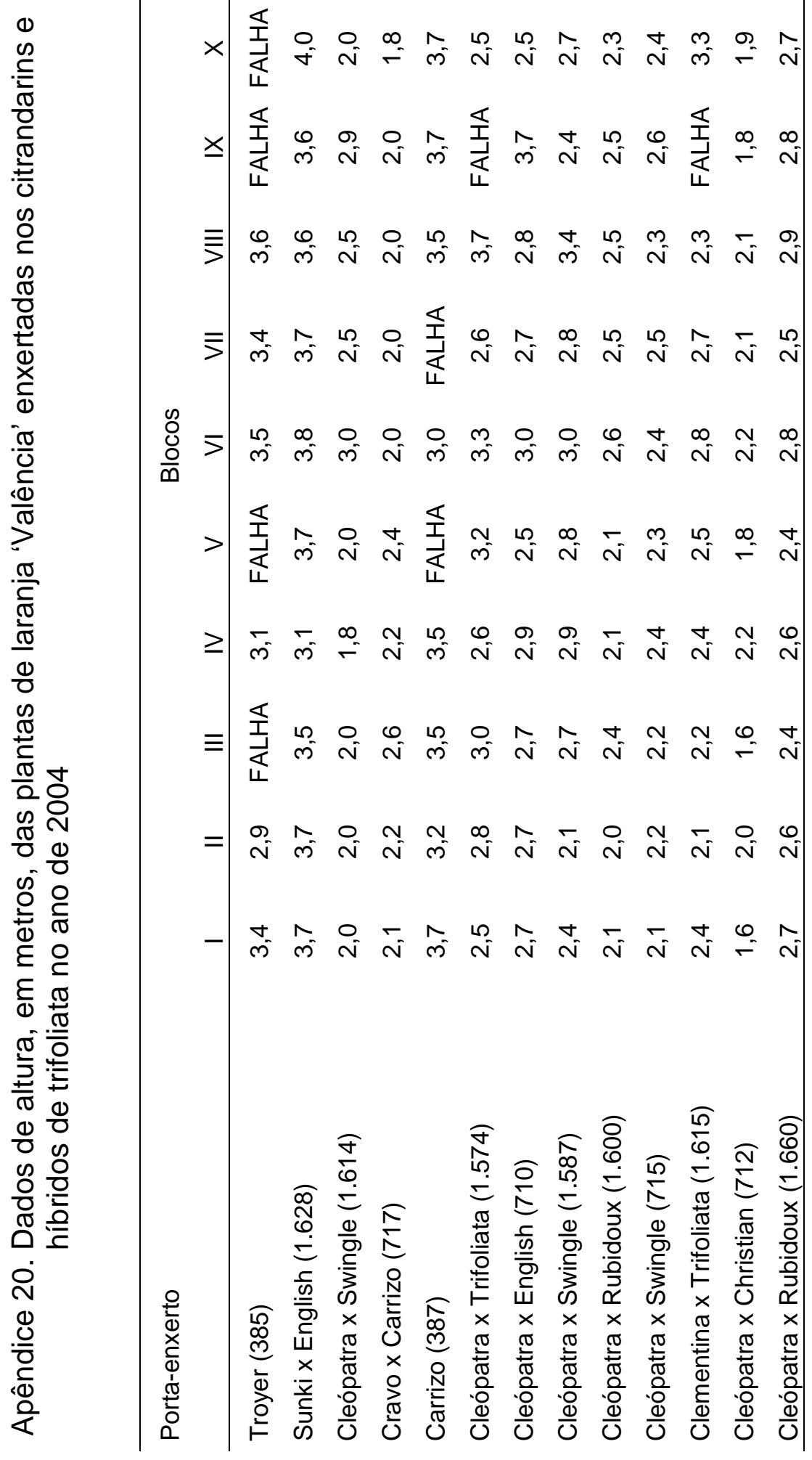




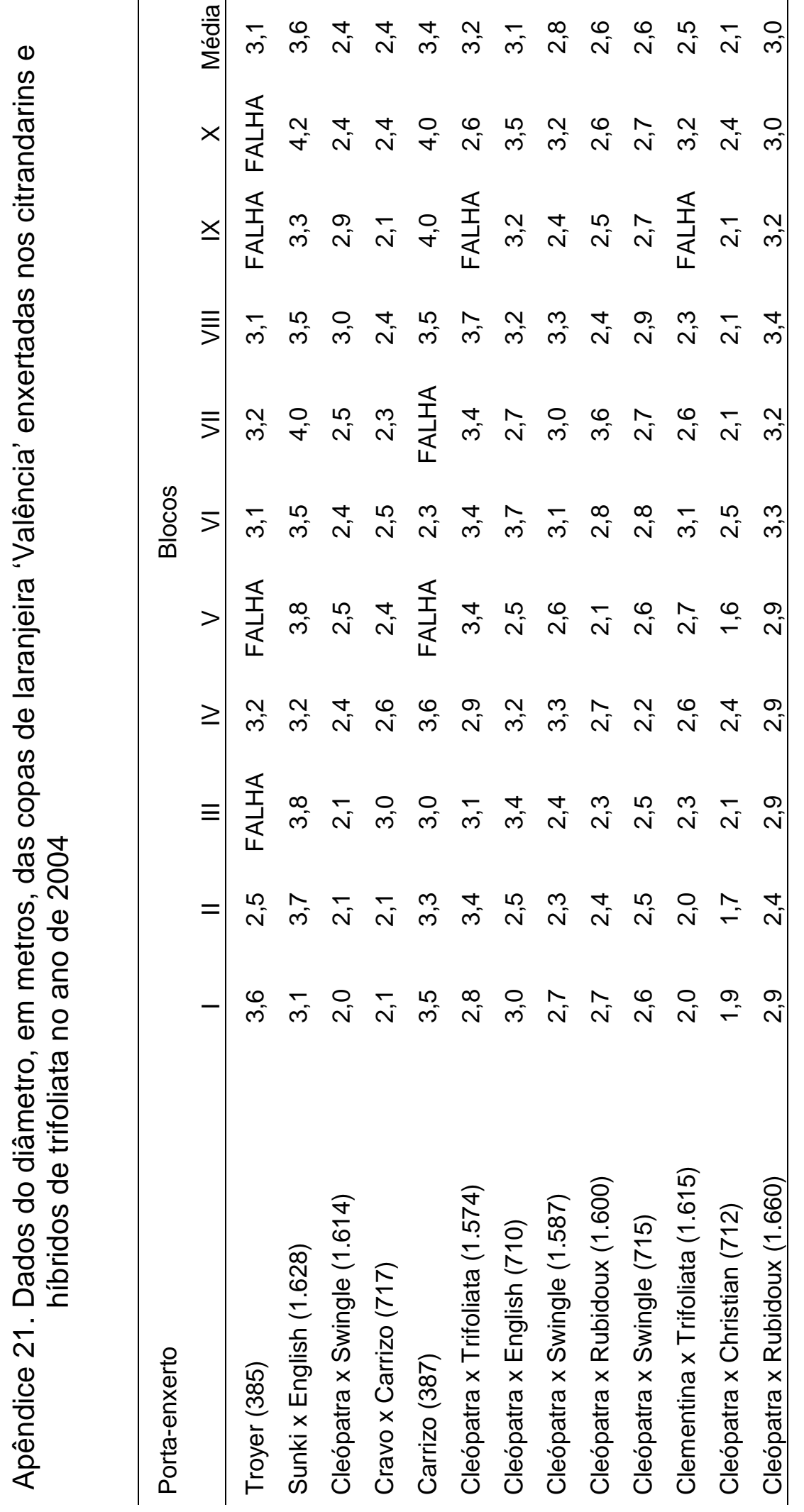




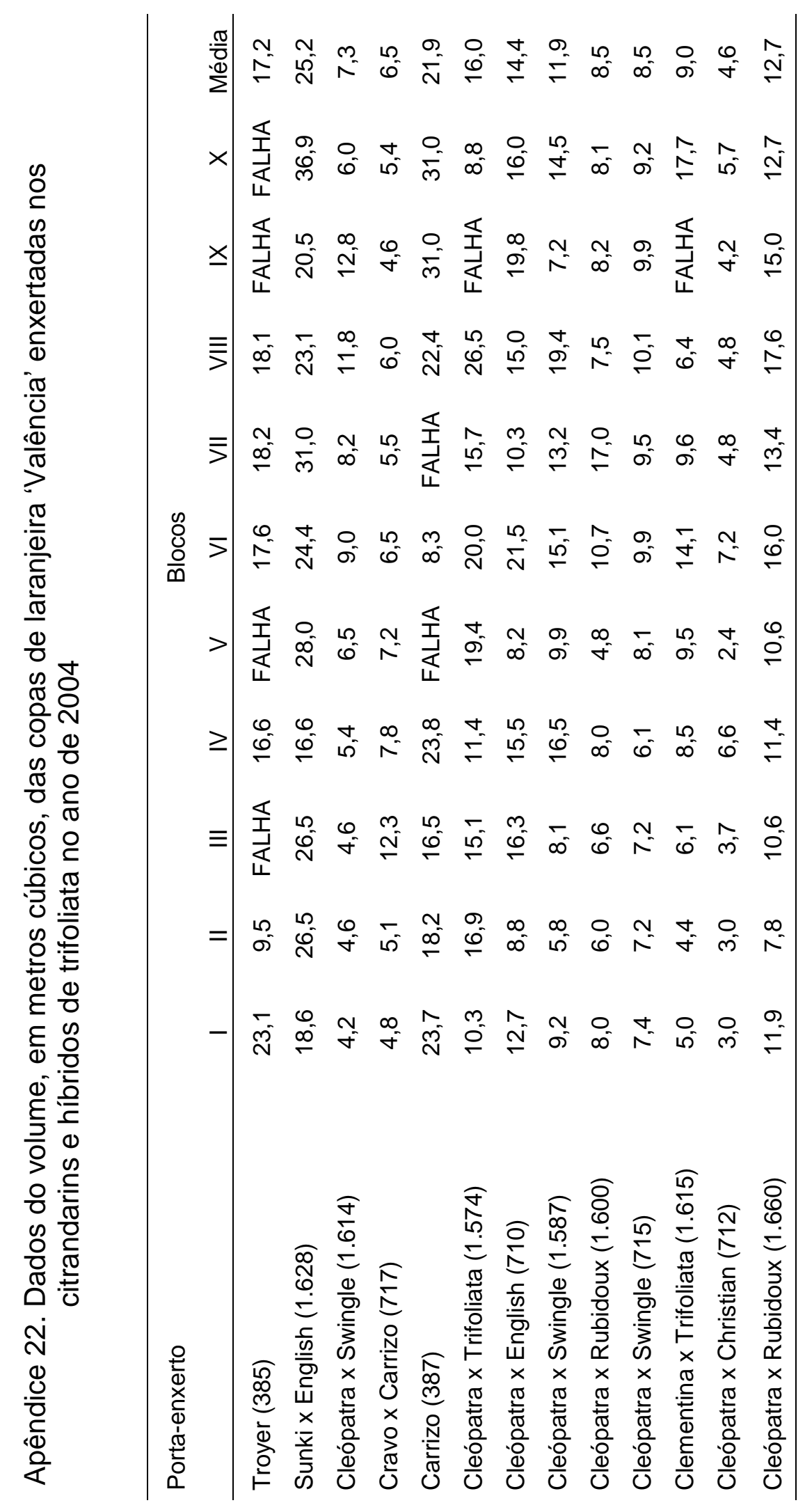


Apêndice 23. Dados de qualidade dos frutos da laranja Valência enxertadas nos citrandarins e outros híbridos de trifoliata em 2001

\begin{tabular}{|c|c|c|c|c|c|c|c|c|c|c|}
\hline Bloco & Porta-enxerto & $\begin{array}{l}\text { peso } \\
\text { fruto }\end{array}$ & altura & largura & $A / L$ & $\begin{array}{c}\text { Rd. } \\
\text { Suco }\end{array}$ & acidez & brix & ratio & s.s \\
\hline \multirow{19}{*}{ II } & Troyer (385) & 176,5 & 7,1 & 7,0 & 1,0 & 50,4 & 1,120 & 11,7 & 10,5 & 2,4 \\
\hline & Sunki x English (1.628) & 230,0 & 7,8 & 7,6 & 1,0 & 49,8 & 1,020 & 11,7 & 11,3 & 2,4 \\
\hline & Cleópatra x Swingle (.1614) & 196,5 & 7,5 & 7,1 & 1,1 & 48,9 & 1,500 & 12,7 & 8,4 & 2,5 \\
\hline & Cravo x Carrizo (717) & 223,5 & 7,4 & 7,5 & 1,0 & 50,6 & 1,260 & 12,2 & 9,7 & 2,5 \\
\hline & Carrizo (387) & 187,5 & 7,3 & 7,0 & 1,0 & 50,7 & 1,120 & 11,7 & 10,4 & 2,4 \\
\hline & Cleópatra x Trifoliata (1.574) & 166,5 & 7,1 & 6,8 & 1,0 & 49,5 & 1,250 & 11,0 & 8,8 & 2,2 \\
\hline & Cleópatra x English (710) & 197,5 & 7,6 & 7,1 & 1,1 & 54,2 & 1,300 & 12,4 & 9,5 & 2,7 \\
\hline & Cleópatra x Swingle (1.587) & 196,0 & 7,4 & 7,1 & 1,1 & 49,7 & 1,390 & 12,4 & 8,9 & 2,5 \\
\hline & Cleópatra x Rubidoux (1.600) & 201,5 & 7,4 & 7,2 & 1,0 & 48,9 & 1,390 & 11,8 & 8,5 & 2,4 \\
\hline & Cleópatra x Swingle (715) & 181,0 & 7,2 & 6,9 & 1,0 & 53,9 & 1,330 & 13,2 & 9,8 & 2,9 \\
\hline & Clementina $x$ Trifoliata (1.615) & 214,0 & 7,5 & 7,4 & 1,0 & 47,0 & 1,370 & 15,3 & 11,1 & 2,9 \\
\hline & Cleópatra x Christian (712) & 141,5 & 6,7 & 6,4 & 1,1 & 52,3 & 1,470 & 14,2 & 9,6 & 3,0 \\
\hline & Cleópatra x Rubidoux (1.660) & 166,0 & 7,0 & 6,7 & 1,0 & 52,4 & 1,570 & 14,4 & 9,1 & 3,1 \\
\hline & Troyer (385) & 210,5 & 7,5 & 7,4 & 1,0 & 52,3 & 1,090 & 11,8 & 10,8 & 2,5 \\
\hline & Sunki x English (1.628) & 218,0 & 7,6 & 7,4 & 1,0 & 51,6 & 1,090 & 11,6 & 10,6 & 2,5 \\
\hline & Cleópatra x Swingle (.1614) & 184,5 & 7,2 & 7,1 & 1,0 & 49,3 & 1,370 & 12,7 & 9,2 & 2,6 \\
\hline & Cravo x Carrizo (717) & 197,0 & 7,6 & 7,1 & 1,1 & 48,2 & 1,290 & 12,5 & 9,6 & 2,5 \\
\hline & Carrizo (387) & 205,0 & 7,4 & 7,3 & 1,0 & 52,7 & 1,130 & 11,5 & 10,1 & 2,5 \\
\hline & Cleópatra x Trifoliata (1.574) & 202,5 & 7,4 & 7,3 & 1,0 & 51,9 & 1,150 & 11,1 & 9,7 & 2,4 \\
\hline \multirow[t]{13}{*}{ VI } & Cleópatra x English (710) & 201,5 & 7,5 & 7,2 & 1,0 & 53,1 & 1,250 & 12,3 & 9,9 & 2,7 \\
\hline & Cleópatra x Swingle (1.587) & 182,5 & 7,1 & 7,0 & 1,0 & 52,6 & 1,360 & 13,7 & 10,0 & 2,9 \\
\hline & Cleópatra x Rubidoux (1.600) & 194,5 & 7,3 & 7,2 & 1,0 & 50,6 & 1,280 & 12,8 & 10,0 & 2,6 \\
\hline & Cleópatra x Swingle (715) & 177,5 & 7,2 & 6,8 & 1,1 & 51,5 & 1,590 & 13,6 & 8,5 & 2,9 \\
\hline & Clementina $x$ Trifoliata (1.615) & 161,5 & 7,1 & 6,7 & 1,1 & 46,1 & 1,460 & 13,1 & 8,9 & 2,5 \\
\hline & Cleópatra x Christian (712) & 224,5 & 7,7 & 7,4 & 1,0 & 49,7 & 1,140 & 12,0 & 8,5 & 2,4 \\
\hline & Cleópatra x Rubidoux (1.660) & 207,5 & 7,5 & 7,3 & 1,0 & 50,4 & 1,380 & 12,3 & 8,9 & 2,5 \\
\hline & Troyer (385) & 191,0 & 7,4 & 7,1 & 1,0 & 50,0 & 1,240 & 12,1 & 9,7 & 2,5 \\
\hline & Sunki x English (1.628) & 194,0 & 7,2 & 7,2 & 1,0 & 49,7 & 1,180 & 11,2 & 9,5 & 2,3 \\
\hline & Cleópatra x Swingle (.1614) & 186,5 & 7,4 & 7,0 & 1,1 & 49,3 & 1,660 & 13,4 & 8,1 & 2,7 \\
\hline & Cravo x Carrizo (717) & 211,5 & 7,6 & 7,3 & 1,0 & 49,2 & 1,200 & 12,1 & 10,1 & 2,4 \\
\hline & Carrizo (387) & 188,5 & 7,3 & 7,1 & 1,0 & 49,1 & 1,200 & 11,8 & 9,8 & 2,4 \\
\hline & Cleópatra x Trifoliata (1.574) & 198,0 & 7,5 & 7,2 & 1,0 & 49,2 & 1,170 & 10,8 & 9,2 & 2,2 \\
\hline \multirow[t]{7}{*}{ VIII } & Cleópatra x English (710) & 188,5 & 7,4 & 7,0 & 1,1 & 51,2 & 1,360 & 12,3 & 9,0 & 2,6 \\
\hline & Cleópatra x Swingle (1.587) & 202,5 & 7,3 & 7,3 & 1,0 & 48,6 & 1,300 & 13,1 & 10,0 & 2,6 \\
\hline & Cleópatra x Rubidoux (1.600) & 220,5 & 7,6 & 7,5 & 1,0 & 48,3 & 1,370 & 12,6 & 9,1 & 2,5 \\
\hline & Cleópatra x Swingle (715) & 166,0 & 6,9 & 6,8 & 1,0 & 51,2 & 1,550 & 13,6 & 8,7 & 2,8 \\
\hline & Clementina $x$ Trifoliata (1.615) & 184,0 & 7,1 & 7,1 & 1,0 & 48,6 & 1,660 & 12,3 & 7,4 & 2,5 \\
\hline & Cleópatra x Christian (712) & 196,0 & 7,4 & 7,1 & 1,0 & 50,3 & 1,510 & 13,0 & 8,6 & 2,7 \\
\hline & Cleópatra x Rubidoux (1.660) & 206,0 & 7,6 & 7,3 & 1,0 & 49,5 & 1,270 & 12,3 & 9,6 & 2,5 \\
\hline
\end{tabular}


Apêndice 24. Dados de qualidade dos frutos da laranja Valência enxertadas nos citrandarins e outros híbridos de trifoliata em 2002

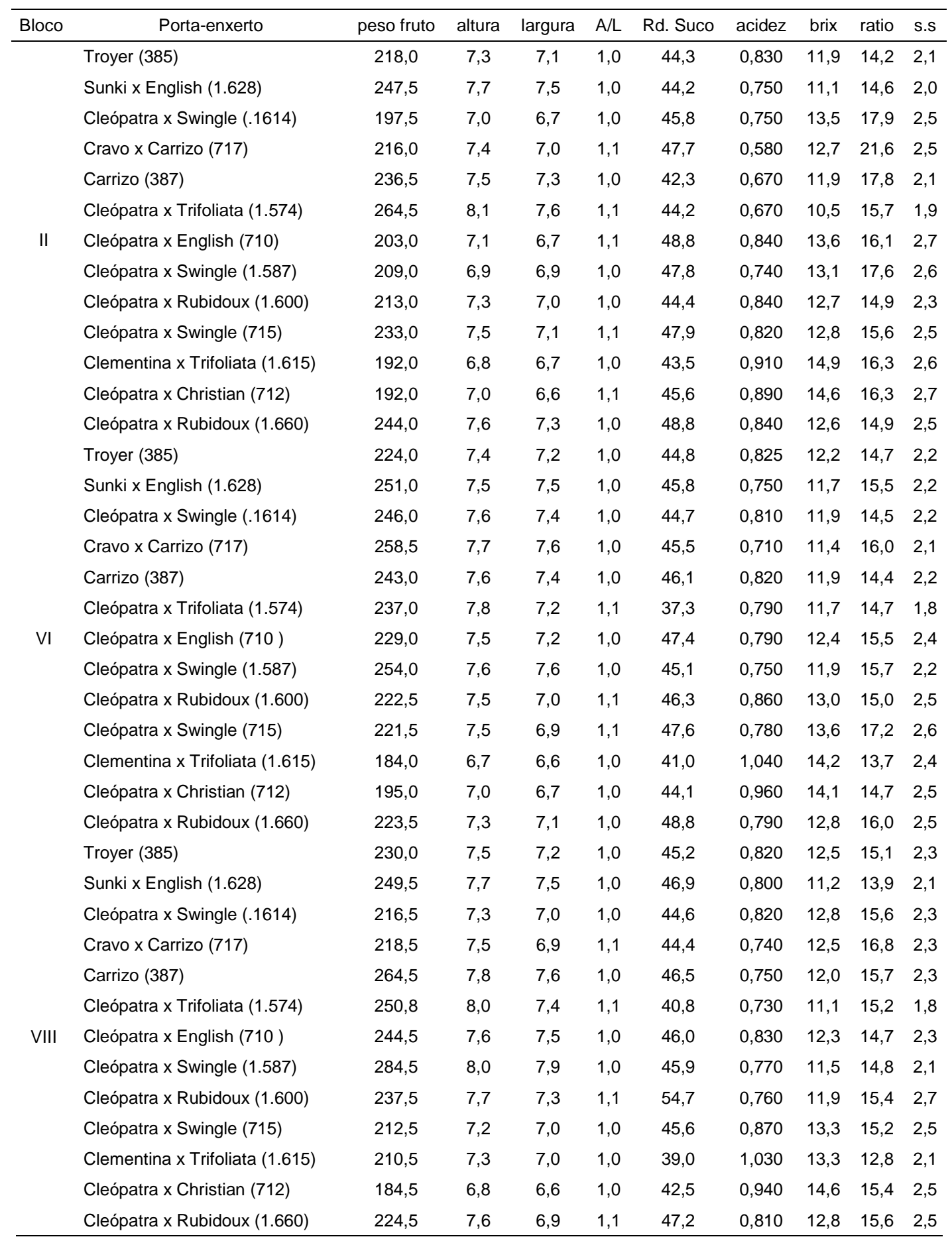


Apêndice 25. Dados de qualidade dos frutos da laranja Valência enxertadas nos citrandarins e outros híbridos de trifoliata em 2003

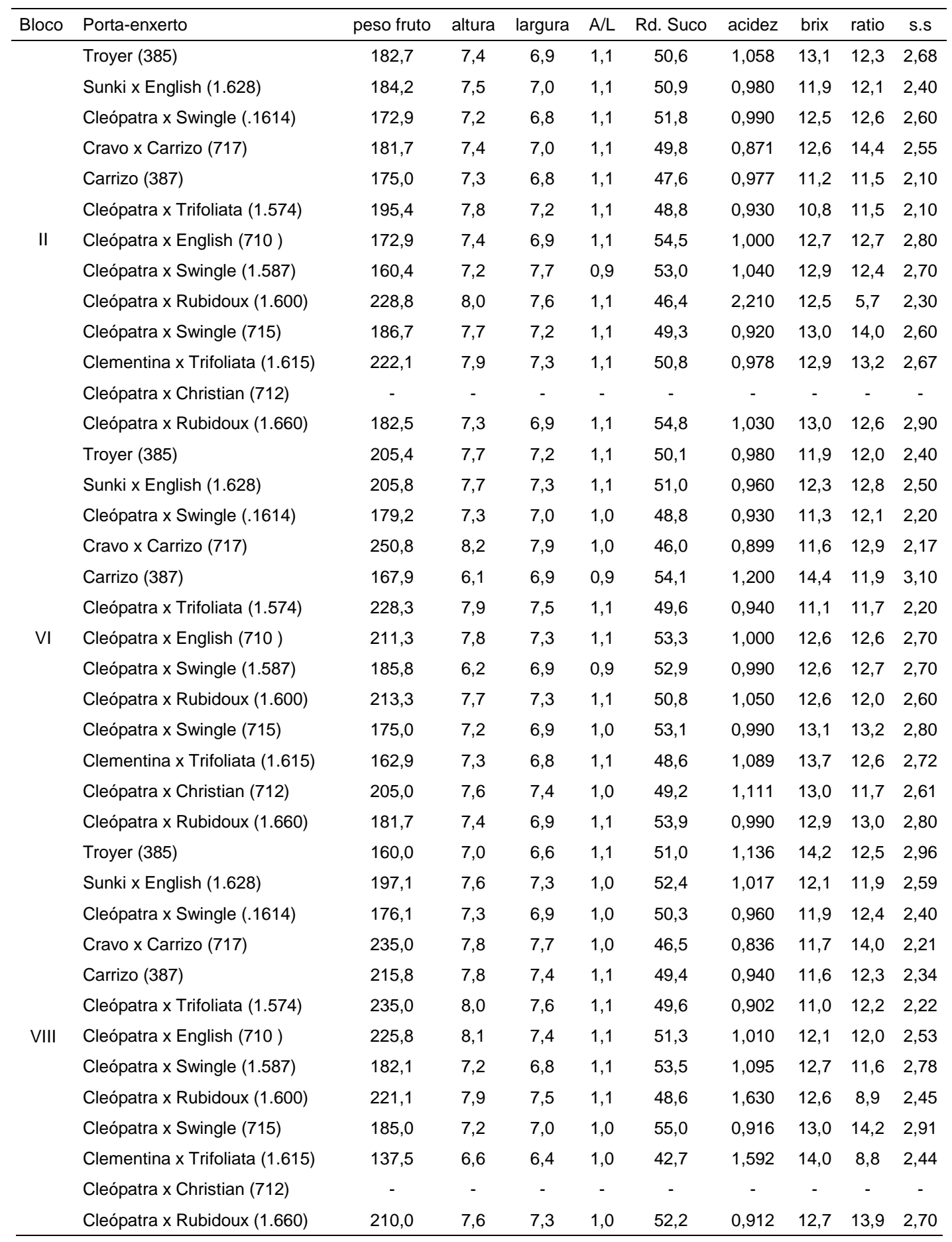


Apêndice 26. Dados de diâmetro, altura e área da lesão provocada por $P$. parasitica, área e porcentagem de área lesionada dos citrandarins e outros híbridos de trifoliata

\begin{tabular}{|c|c|c|c|c|c|c|}
\hline \multirow[t]{2}{*}{ Porta-enxerto } & \multirow[t]{2}{*}{ Repetição } & \multicolumn{3}{|c|}{ Lesão de Phytophthora } & \multicolumn{2}{|c|}{ Porta-enxerto } \\
\hline & & Diâmetro & Altura & Área & Área & Área lesionada \\
\hline & & $\mathrm{mn}$ & & $\mathrm{mm}^{2}$ & $\mathrm{~mm}^{2}$ & $(\%)$ \\
\hline \multirow{10}{*}{ Cleópatra x Christian (712) } & 1 & 3 & 5 & 11,8 & 40 & 29 \\
\hline & 2 & 2 & 5 & 7,9 & 40 & 20 \\
\hline & 3 & 4 & 7 & 22,0 & 40 & 55 \\
\hline & 4 & 3 & 6 & 14,1 & 40 & 35 \\
\hline & 5 & 2 & 5 & 7,9 & 40 & 20 \\
\hline & 6 & 4 & 7 & 22,0 & 50 & 44 \\
\hline & 7 & 3 & 6 & 14,1 & 50 & 28 \\
\hline & 8 & 3 & 5 & 11,8 & 40 & 29 \\
\hline & 9 & 3 & 8 & 18,8 & 40 & 47 \\
\hline & 10 & 3 & 9 & 21,2 & 40 & 53 \\
\hline \multirow{10}{*}{ Cravo x Carrizo (717) } & 1 & 2 & 5 & 7,9 & 40 & 20 \\
\hline & 2 & 2 & 5 & 7,9 & 30 & 26 \\
\hline & 3 & 3 & 5 & 11,8 & 50 & 24 \\
\hline & 4 & 2 & 5 & 7,9 & 40 & 20 \\
\hline & 5 & 2 & 5 & 7,9 & 50 & 16 \\
\hline & 6 & 2 & 6 & 9,4 & 40 & 24 \\
\hline & 7 & 2 & 6 & 9,4 & 50 & 19 \\
\hline & 8 & 2 & 5 & 7,9 & 50 & 16 \\
\hline & 9 & 1 & 4 & 3,1 & 50 & 6 \\
\hline & 10 & 2 & 3 & 4,7 & 40 & 12 \\
\hline \multirow{10}{*}{ Cleópatra x Swingle (1.614) } & 1 & 3 & 7 & 16,5 & 40 & 41 \\
\hline & 2 & 3 & 6 & 14,1 & 40 & 35 \\
\hline & 3 & 2 & 7 & 11,0 & 40 & 27 \\
\hline & 4 & 3 & 6 & 14,1 & 40 & 35 \\
\hline & 5 & 2 & 6 & 9,4 & 40 & 24 \\
\hline & 6 & 2 & 5 & 7,9 & 40 & 20 \\
\hline & 7 & 3 & 5 & 11,8 & 40 & 29 \\
\hline & 8 & 2 & 5 & 7,9 & 30 & 26 \\
\hline & 9 & 2 & 6 & 9,4 & 40 & 24 \\
\hline & 10 & 3 & 7 & 16,5 & 40 & 41 \\
\hline
\end{tabular}


Apêndice 26. Dados de diâmetro, altura e área da lesão provocada por $P$. parasitica, área e porcentagem de área lesionada dos citrandarins e outros híbridos de trifoliata

Cleópatra x Swingle (1.587)

Cleópatra x Rubidoux (1.600)

Clementina x Trifoliata (1615)

\begin{tabular}{|c|c|c|c|c|}
\hline 1 & 2 & 5 & 7,9 & 40 \\
\hline 2 & 2 & 3 & 4,7 & 40 \\
\hline 3 & 4 & 6 & 18,8 & 50 \\
\hline 4 & 2 & 4 & 6,3 & 40 \\
\hline 5 & 2 & 3 & 4,7 & 40 \\
\hline 6 & 2 & 4 & 6,3 & 50 \\
\hline 7 & 2 & 3 & 4,7 & 40 \\
\hline 8 & 2 & 3 & 4,7 & 50 \\
\hline 9 & 3 & 3 & 7,1 & 40 \\
\hline 10 & 2 & 3 & 4,7 & 50 \\
\hline 1 & 1 & 4 & 3,1 & 40 \\
\hline 2 & 1 & 3 & 2,4 & 40 \\
\hline 3 & 2 & 3 & 4,7 & 50 \\
\hline 4 & 2 & 4 & 6,3 & 40 \\
\hline 5 & 2 & 4 & 6,3 & 30 \\
\hline 6 & 2 & 4 & 6,3 & 40 \\
\hline 7 & 2 & 5 & 7,9 & 40 \\
\hline 8 & 2 & 3 & 4,7 & 50 \\
\hline 9 & 3 & 5 & 11,8 & 40 \\
\hline 10 & 3 & 6 & 14,1 & 30 \\
\hline 1 & 3 & 6 & 14,1 & 50 \\
\hline 2 & 2 & 4 & 6,3 & 50 \\
\hline 3 & 2 & 4 & 6,3 & 50 \\
\hline 4 & 2 & 6 & 9,4 & 40 \\
\hline 5 & 2 & 5 & 7,9 & 50 \\
\hline 6 & 2 & 4 & 6,3 & 50 \\
\hline 7 & 3 & 7 & 16,5 & 40 \\
\hline 8 & 3 & 4 & 9,4 & 40 \\
\hline 9 & 2 & 5 & 7,9 & 40 \\
\hline 10 & 1 & 4 & 3,1 & 40 \\
\hline
\end{tabular}


Apêndice 26. Dados de diâmetro, altura e área da lesão provocada por $P$. parasitica, área e porcentagem de área lesionada dos citrandarins e outros híbridos de trifoliata

Cleópatra x Trifoliata (1.574)

Sunki x English (1.628)

Cleópatra x English (710)

\begin{tabular}{|c|c|c|c|c|c|}
\hline 1 & 2 & 5 & 7,9 & 40 & 20 \\
\hline 2 & 2 & 5 & 7,9 & 40 & 20 \\
\hline 3 & 1 & 3 & 2,4 & 40 & 6 \\
\hline 4 & 2 & 5 & 7,9 & 40 & 20 \\
\hline 5 & 2 & 5 & 7,9 & 40 & 20 \\
\hline 6 & 2 & 5 & 7,9 & 40 & 20 \\
\hline 7 & 1 & 5 & 3,9 & 50 & 8 \\
\hline 8 & 3 & 4 & 9,4 & 40 & 24 \\
\hline 9 & 2 & 4 & 6,3 & 40 & 16 \\
\hline 10 & 2 & 4 & 6,3 & 40 & 16 \\
\hline 1 & 3 & 8 & 18,8 & 40 & 47 \\
\hline 2 & 3 & 9 & 21,2 & 40 & 53 \\
\hline 3 & 3 & 9 & 21,2 & 40 & 53 \\
\hline 4 & 3 & 7 & 16,5 & 40 & 41 \\
\hline 5 & 3 & 6 & 14,1 & 40 & 35 \\
\hline 6 & 2 & 8 & 12,6 & 40 & 31 \\
\hline 7 & 2 & 7 & 11,0 & 40 & 27 \\
\hline 8 & 2 & 7 & 11,0 & 40 & 27 \\
\hline 9 & 2 & 6 & 9,4 & 40 & 24 \\
\hline 10 & 3 & 6 & 14,1 & 50 & 28 \\
\hline 1 & 3 & 10 & 23,6 & 50 & 47 \\
\hline 2 & 2 & 6 & 9,4 & 40 & 24 \\
\hline 3 & 3 & 9 & 21,2 & 50 & 42 \\
\hline 4 & 3 & 10 & 23,6 & 40 & 59 \\
\hline 5 & 2 & 9 & 14,1 & 40 & 35 \\
\hline 6 & 3 & 10 & 23,6 & 30 & 79 \\
\hline 7 & 3 & 8 & 18,8 & 40 & 47 \\
\hline 8 & 2 & 10 & 15,7 & 50 & 31 \\
\hline 9 & 3 & 9 & 21,2 & 40 & 53 \\
\hline 10 & 4 & 9 & 28,3 & 50 & 57 \\
\hline
\end{tabular}


Apêndice 26. Dados de diâmetro, altura e área da lesão provocada por $P$. parasitica, área e porcentagem de área lesionada dos citrandarins e outros híbridos de trifoliata

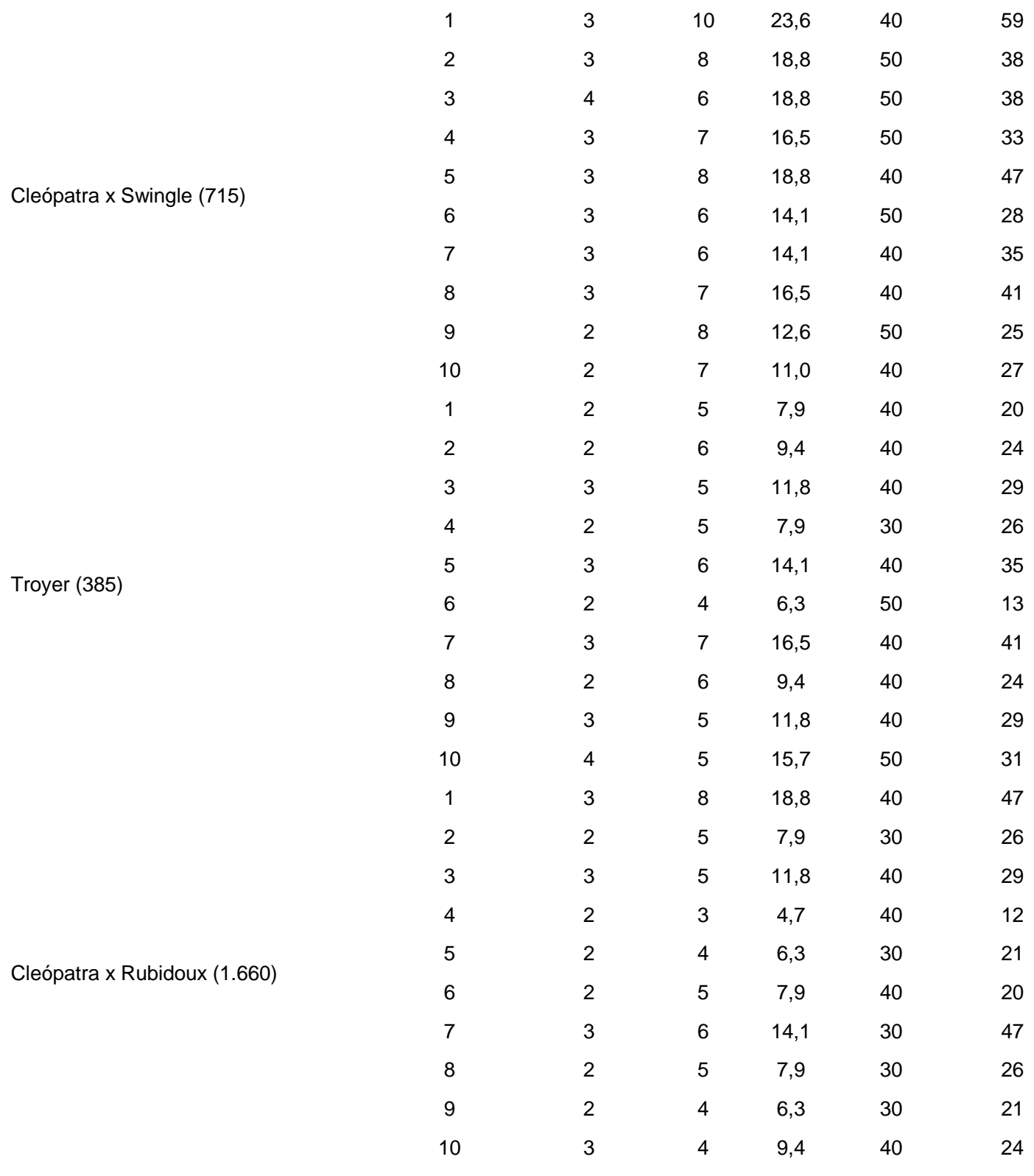


Apêndice 26. Dados de diâmetro, altura e área da lesão provocada por $P$. parasitica, área e porcentagem de área lesionada dos citrandarins e outros híbridos de trifoliata

\begin{tabular}{ccccccc} 
& 1 & 3 & 6 & 14,1 & 40 & 35 \\
Carrizo (387) & 2 & 2 & 5 & 7,9 & 40 & 20 \\
& 3 & 3 & 7 & 16,5 & 40 & 41 \\
& 4 & 2 & 5 & 7,9 & 50 & 16 \\
& 5 & 3 & 5 & 11,8 & 40 & 29 \\
& 6 & 3 & 4 & 9,4 & 40 & 24 \\
& 7 & 3 & 6 & 14,1 & 40 & 35 \\
& 8 & 3 & 7 & 16,5 & 40 & 41 \\
& 9 & 3 & 6 & 14,1 & 40 & 35 \\
\hline
\end{tabular}




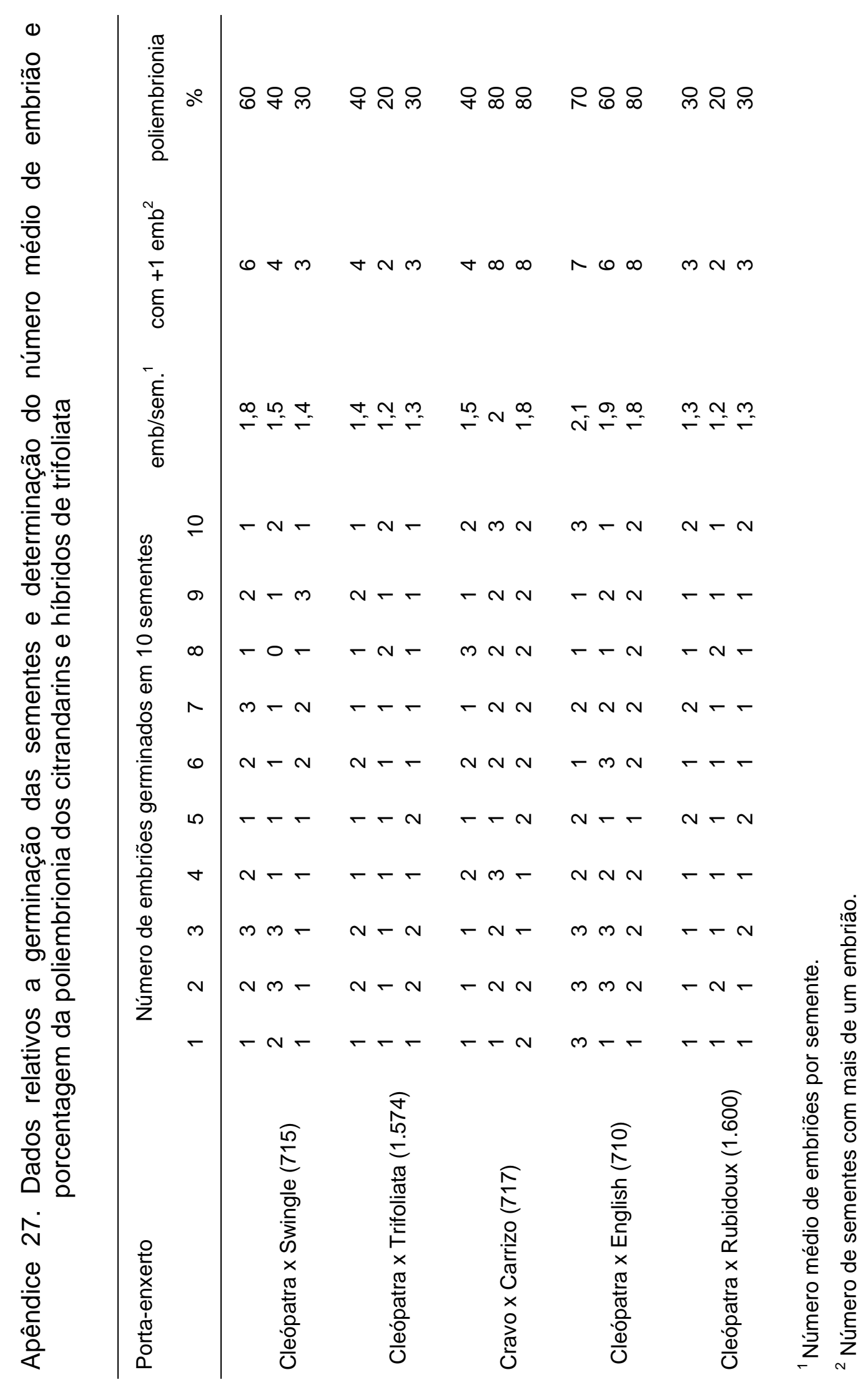




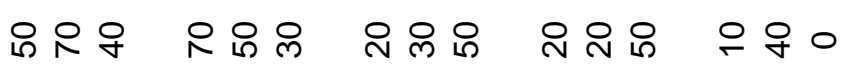

0

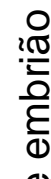

$\frac{0}{0}$

$\ln \pi$ n

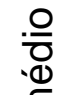

O

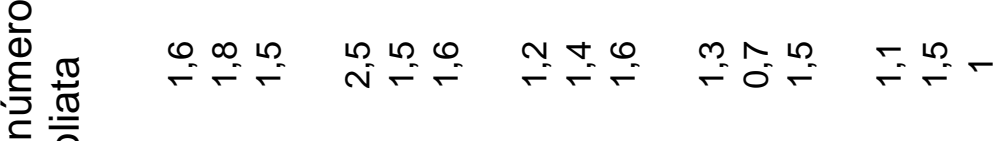
응 은

응

iণে $\frac{0}{0}$ Nm- - m

Un

ชั

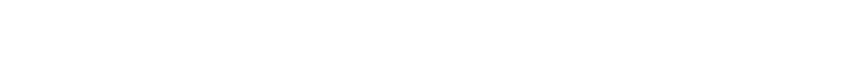

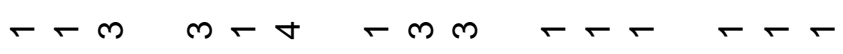
N- m-

⿻

$\stackrel{\oplus}{\stackrel{0}{0}}$

它

है

凹

ণิ ช

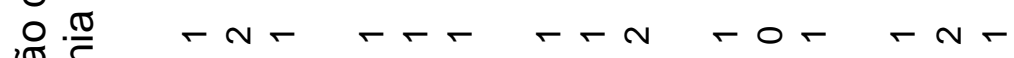

نู

전

.$\stackrel{ }{=}$

है

可

(ে)

is $\frac{\pi}{0}$

$\geq \varepsilon$

$\widetilde{\sigma}$

Ф)

ल) 范

응 잉

它 음

స̃

으

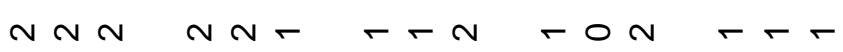

$-T h \quad+N-N-T-m-$

$-n n$ nn- n-n $-0 n-n-$

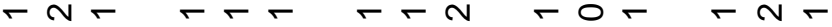

$m \sim-N \cap N--N \cap N--$

$-m-m-m-n-r-r$

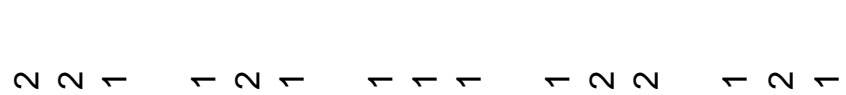

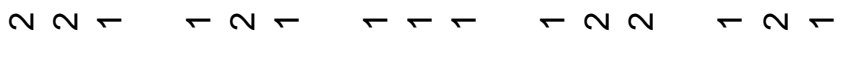

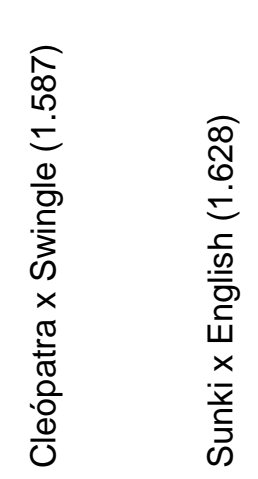

\begin{tabular}{l}
$\widehat{\sigma}$ \\
6 \\
$=$ \\
0 \\
$\frac{0}{0}$ \\
$\frac{5}{3}$ \\
0 \\
$\times$ \\
$\frac{\pi}{5}$ \\
$\frac{0}{0}$ \\
$\frac{0}{0}$ \\
\hline 0
\end{tabular}

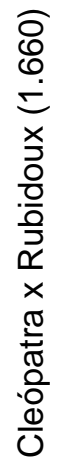

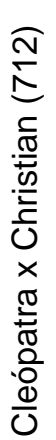

